PNNL-18464

\title{
Commercial Lighting Solutions, Webtool Peer Review Report
}

Carol Jones, Associate IALD, IESNA, LC, Pacific Northwest National Laboratory

Tracy Meyer, LC, Pacific Northwest National Laboratory

February 2009

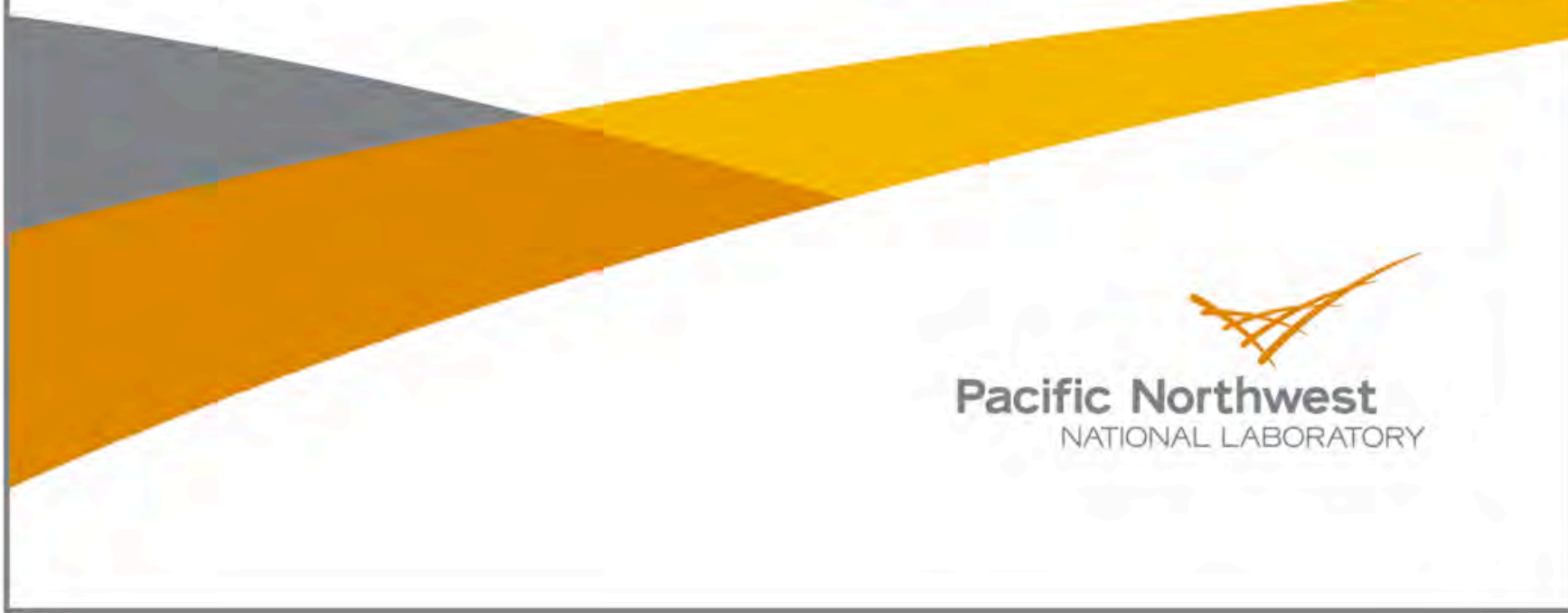




\title{
DISCLAIMER
}

This report was prepared as an account of work sponsored by an agency of the United States Government. Neither the United States Government nor any agency thereof, nor Battelle Memorial Institute, nor any of their employees, makes any warranty, express or implied, or assumes any legal liability or responsibility for the accuracy, completeness, or usefulness of any information, apparatus, product, or process disclosed, or represents that its use would not infringe privately owned rights. Reference herein to any specific commercial product, process, or service by trade name, trademark, manufacturer, or otherwise does not necessarily constitute or imply its endorsement, recommendation, or favoring by the United States Government or any agency thereof, or Battelle Memorial Institute. The views and opinions of authors expressed herein do not necessarily state or reflect those of the United States Government or any agency thereof.

\author{
PACIFIC NORTHWEST NATIONAL LABORATORY \\ operated by \\ BATTELLE \\ for the \\ UNITED STATES DEPARTMENT OF ENERGY \\ under Contract DE-AC05-76RL01830 \\ Printed in the United States of America \\ Available to DOE and DOE contractors from the \\ Office of Scientific and Technical Information, \\ P.O. Box 62, Oak Ridge, TN 37831-0062; \\ ph: (865) 576-8401 \\ fax: $(865) 576-5728$ \\ email: reports@adonis.osti.gov
}

Available to the public from the National Technical Information Service,

U.S. Department of Commerce, 5285 Port Royal Rd., Springfield, VA 22161

ph: (800) 553-6847

fax: $(703) 605-6900$

email: orders@ntis.fedworld.gov

online ordering: http://www.ntis.gov/ordering.htm 


\title{
Commercial Lighting Solutions, Webtool Peer Review Report
}

\author{
Carol Jones \\ Tracy Meyer
}

February 2009

Prepared for the U.S. Department of Energy

Office of Energy Efficiency and Renewable Energy

Federal Energy Management Program

Under Contract DE-AC05-76RLO 1830

Pacific Northwest National Laboratory

Richland, Washington 99352 


\section{Executive Summary}

The Commercial Lighting Solutions (CLS) project directly supports the U.S. Department of Energy's Commercial Building Energy Alliance efforts to design high performance buildings. CLS creates energy efficient best practice lighting designs for widespread use, and they are made available to users via an interactive webtool that both educates and guides the end user through the application of the Lighting Solutions. This report summarizes the peer review of the beta version of the CLS webtool, which contains retail box lighting solutions.

The methodology for the peer review process included data collection (stakeholder input), analysis of the comments, and organization of the input into categories for prioritization of the comments against a set of criteria. Based on this process, recommendations were developed about which feedback should be addressed for the release of version 1.0 of the webtool at the Lightfair conference in New York City in May 2009.

Due to the volume of data ( $\sim 500$ comments) the methodology for addressing the peer review comments was central to the success of the ultimate goal of improving the tool. The comments were first imported into a master spreadsheet, and then grouped and organized in several layers. Solutions to each comment were then rated by importance and feasibility to determine the practicality of resolving the concerns of the commenter in the short-term or long-term. The rating system was used as an analytical tool, but the results were viewed thoughtfully to ensure that they were not the sole the factor in determining which comments were recommended for near-term resolution.

The report provides a list of the top ten most significant and relevant improvements that will be made within the webtool for version 1.0 as well as appendices containing the short-term priorities in additional detail. Peer review comments that are considered high priority by the reviewers and the CLS team but cannot be completed for Version 1.0 are listed as long-term recommendations. 


\section{Contents}

EXECUTIVE SUMMARY iii

1.0 BACKGROUND 1

1.1 Commercial Lighting Solutions and the Commercial Buildings Energy Alliances 1

1.2 Commercial Lighting Solutions Webtool 1

1.3 Peer Review Task Description 1

1.4 Objectives 2

2.0 METHODOLOGY 2

2.1 Peer Review Data collection 2

2.1.1. Reviewers 2

2.1.2. Webtool Content 2

2.1.3. Peer Review Input Format 3

2.1.4. Process 3

2.2 Analysis and Prioritization 4

2.2.1. Spreadsheet Summary 4

2.2.2. Comments Assigned to Actions/Solutions 5

2.2.3. Importance and Feasibility Ratings 5

2.2.4. Overall Rankings, Short-term and Long-term Goals 6

2.2.5. Unrated Comments

$\begin{array}{lll}3.0 & \text { RECOMMENDATIONS } & 7\end{array}$

3.1 Development of Recommendations 7

3.1.1. Prioritization Ranges $\quad 8$

3.1.2. Exceptions to Prioritization Ranges $\quad 8$

3.2 Top Ten List of Priority Short-Term Recommendations $\quad 8$

3.3 TRAC Tickets 9

3.4 Peer Review Input Data 9

3.5 List of Long-Term Priority Recommendations 9

4.0 CONCLUSION 9

APPENDIX A: REVIEWER LIST A-1

APPENDIX B: WEBTOOL PAGE REFERENCE FILE B-1

APPENDIX C: PEER REVIEW INPUT SPREADSHEET $\quad$ C-1

APPENDIX D: TRAC TICKET LIST

APPENDIX E: MASTER COMMENTS LIST E-1 


\section{Tables}

Table 1. Importance Ratings 5

Table 2. Feasibility Ratings. 6 


\subsection{Background}

\subsection{Commercial Lighting Solutions and the Commercial Buildings Energy Alliances}

Commercial buildings currently account for 18 percent of total U.S. energy consumption, and are projected by the Energy Information Administration to experience significant growth over the next two decades. To increase the energy efficiency of this sector, especially in new construction, the U.S. Department of Energy (DOE) has created three new Commercial Building Energy Alliances (CBEAs) that are designed to minimize the energy consumption and environmental impact of commercial buildings. The Alliances will contribute to DOE's overarching goal of having cost-effective net-zero energy commercial buildings on the market by 2025-gridconnected buildings that, over the course of a year, generate as much energy as they consume. The CBEAs focus on the following sectors: Retail, Commercial properties (leased space, offices, shopping malls, and hospitality), and Institutions (including colleges and universities, hospitals, and health care facilities). Alliance members seek to reduce energy consumption by significant levels in their new and existing buildings.

The Commercial Lighting Solutions (CLS) project directly supports the Commercial Building Energy Alliance efforts to design high performance buildings. Lighting Solutions optimized for energy efficiency, cost effectiveness, and occupant satisfaction are critical to the end-product success of 50\% (and greater) energy savings. Any endeavor to realize deep energy savings must include Lighting Solutions as part of its "solution set" because fully one-quarter of commercial buildings energy use (on average) is lighting; sector wide, commercial buildings, require 4.6 source quads per year to provide illumination services. ${ }^{1}$

Currently Lighting Solutions have been developed for retail box buildings and are in development for offices. The CLS Webtool has been developed to deliver the Lighting Solutions to the Alliances and the market at large. Critical to the success of the webtool is stakeholder input, which has been gathered via a peer review input process. This report summarizes the findings of the CLS Peer Review task.

\subsection{Commercial Lighting Solutions Webtool}

The webtool is the delivery mechanism for the Lighting Solutions. The webtool is critical to widespread usage of the Lighting Solutions and includes a strong interactive element that both educates and guides the end user through the application of the Lighting Solutions. The webtool is also critical for capturing impact and usage of the solutions.

\subsection{Peer Review Task Description}

The Peer Review task covers the process by which stakeholders have input to the Lighting Solutions. The Peer Review process described in this report is limited to the beta version of the CLS webtool, which contains retail box lighting solutions. As development continues on the webtool, the peer review will be phased and ongoing in support of new solutions, continuous improvement to existing solutions, and partner-contributed solutions.

\footnotetext{
${ }^{1} 2008$ Buildings Energy Data Book http://buildingsdatabook.eren.doe.gov/docs/xls_pdf/3.1.4.pdf
}

February 2009 


\subsection{Objectives}

The objectives of this work were to accomplish the following:

(1) Gather high-quality feedback on the CLS webtool from a representative group of stakeholders.

(2) Analyze the peer review input data to categorize similar comments, determine possible solutions, and weigh and prioritize input against a set of decision criteria.

(3) Develop recommendations about tasks that should be undertaken to improve the webtool with the time and funds that are available in the short term.

(4) Develop recommendations about tasks that should be considered as a longer-term goals for the continuous improvement of the webtool.

\subsection{Methodology}

The methodology for the peer review process included data collection (stakeholder input), analysis of the comments, and organization of the input into categories for prioritization of the comments against a set of criteria. Based on this process, recommendations were developed about which feedback should be addressed for the release of version 1.0 of the webtool.

\subsection{Peer Review Data collection}

The goal of data collection was to capture sufficient feedback from each of our target user groups, in a way that allowed us to process comments that was efficient and thorough.

\subsubsection{Reviewers}

In order to collect the level of detail desired from the peer review process, input was requested from professionals across the range of fields that would use and benefit from the tool. A list of potential reviewers was compiled including retailers, lighting designers, engineers, professional associations, state energy programs, energy-efficiency program sponsors, utilities and members of the core team. The representation of members of various fields ensured that all aspects of the tool would be considered analytically from many possible angles.

\subsubsection{Webtool Content}

The peer review included the following pages of the webtool: (1) sign-in, (2) new project, (3) project description, (4) key plans, (5) vignette lists, (6) individual vignettes, (7) control strategies, and (8) download material. These elements were shared with the reviewers in a screen capture file with reference page names (see Appendix B).

Lighting equipment descriptions were included in the peer review process in the vignette descriptions and the luminaire schedule with only one exception. Luminaire photometric performance specifications are being developed and reviewed through an ongoing separate process with stakeholders that have expertise in luminaire design. Determination of the photometric performance specifications will require the use of a luminaire verification webtool that analyzes IESNA photometric files so that criteria can be established in collaboration with the National Electrical Manufacturer's Association (NEMA). 


\subsubsection{Peer Review Input Format}

In order to capture all of the feedback in an easily quantifiable manner, an excel spreadsheet was designed to help the reviewers categorize their impressions of the webtool (see Appendix C). The spreadsheet provided space for reviewers to include important information regarding their operating system and the web browser they used so the web team could address functionality and compatibility issues once all of the input was received. Each comment was assigned a reference number to more easily track the progress of addressing the many comments received. There was also a column to record the store type and reference web page to assure that the context of the comment was sufficiently understood.

There were six categories in the spreadsheet that reviewers were asked to consider including:

(1) appearance/aesthetics

(2) ease of use/flow

(3) functionality

(4) content

(5) download material

(6) general comments

Providing guidance questions encouraged a more comprehensive review than might otherwise have occurred, and also helped with the data analysis process.

As the finalized comments were received they were compiled into a master spreadsheet for analysis, diagnosis, and resolution.

\subsubsection{Process}

Over the entirety of the peer review period, several hundred potential reviewers were invited to comment. This approach was not very effective due to the congested schedules of the potential reviewers. Ultimately the project team changed to a more proactive approach and scheduled specific meeting times with people to ensure that feedback was obtained in a manner similar to qualitative interviews. Most frequently an online meeting approach was used, so that the CLS team could actually watch the reviewer navigate through the tool, and capture thoughts and questions exactly as they came up. Often through this dialogue the interviewer was able to more clearly identify the root cause of the problems, and identify potential solutions that would resolve concerns. The interviewer acted as the recorder for the feedback of the reviewer, and then sent the spreadsheet input form to the reviewer so they could confirm the validity of the comments and elaborate upon additional aspects of the tool as they continued to spend time working with it online.

Feedback on this approach was very positive, from reviewers as well as the PNNL team. Reviewers felt that they could concentrate better on the review process because they didn't have to go back and forth between the webtool and typing their thoughts into the comment sheet. Additionally, the PNNL interviewer was often able to catch issues and problems through the observation process that either would not have been noticed by the reviewer, or would not have been characterized clearly. The dialogue was also very useful in developing specific ideas about potential improvements to the webtool. After reviewing the peer review comments, the PNNL 
web development team said that the comments were significantly more useful and actionable than typical peer review input due to the live meeting interview approach.

The focus of the peer review was to find problems and improvement opportunities, so the positive comments were removed from the evaluation process. Positive comments were unrated and are contained in a separate list within the data set in Appendix E. Speaking generally, reviewers almost universally liked the aesthetic appearance of the tool, the simplicity of the workflow, and the ability to see energy savings impacts as choices were made. The goal of the team will be to make improvements to the tool without losing the features that were widely appreciated by reviewers.

By the end of the peer review input period, 30 reviewers had either been interviewed and/or provided detailed written input for a total of $\sim 500$ comments.

\subsection{Analysis and Prioritization}

Once all of the comments were imported into a master spreadsheet, they were grouped and organized into several categories. Strategies for each comment were then rated in several categories to determine the practicality of resolving the concerns of the commenter. After several additional filters to the data, short term and long term goals were established based on the ratings. The rating system was used as an analytical tool, but the results were viewed thoughtfully to ensure that they were not the sole the factor in determining the practicality of comment resolution.

\subsubsection{Spreadsheet Summary}

Columns in the spreadsheet were expanded from the truncated peer review input form to support the data analysis, including the following: commenter ID number, action/solution, importance, feasibility, short-term rating, long-term rating, status, and PIC (person in charge).

The comment type column retained the five general categories reviewers were asked to recognize on the peer review input form. Ratings on a scale of 1-5 were assigned to frequency and importance of the comments that ultimately established the "importance" rating, while the same rating scale for ease of implementation, duration, and risk/complication were ultimately used to determine the "feasibility" rating as discussed in section 2.2.3. The importance and feasibility ratings were weighted together differently to attain the overall rating for the short and long term. This process is discussed in detail in section 2.2.4. The final two columns helped to further categorize and track the comments. The action/solution column linked to a list of more general issues that grouped comments with similar solutions. The status column is the working record of where the PNNL team stands in respect to resolving the issue.

Due to the diversity of the comments, separate tabs were created to support the analysis process including (1) design, (2) webteam, (3) text edits, (4) content, (5) download material, and (6) positive comments. The primary objective of sorting the comments in this way simplified the process of receiving feedback regarding the accuracy of the feasibility ratings from members of the PNNL team that would ultimately perform the tasks that addressed the comments, i.e. the webteam regarding issues of browser functionality. This organization of comments also allowed for more specific action/solution categories to be assigned within the tabs. 


\subsubsection{Comments Assigned to Actions/Solutions}

With the large quantity of comments received, it was important to divide them into refined categories that represented the type of action that would yield a solution to the concern expressed. Comments were turned into proposed actions so that they could be rated in terms of importance and feasibility. For example, on the design tab comments were grouped into actions/solutions such as luminaire changes for comments that provided input about luminaire choices or validation for comments that expressed confusion about the design determination or application process that should be clarified in the webtool. Grouping comments on the text edit tab into either specific text edits and general text edits provided guidance in establishing general tasks, such as "text content edits" that encompass each minor text edit. When the task is believed to be resolved, each comment that was categorized under the given action/solution can then be addressed individually to ensure completion.

This process allowed us to review similar comments in proximity to each other, and supported the process of turning comments into TRAC tickets for future delegation and resolution by the team. The TRAC tool is an online resource that allows users to set up "tickets" as specific tasks that link to full descriptions that can include specific comments. Each ticket is categorized by the component of the webtool it addressed, i.e. software, database, PDF, or content, and assigned to a person in charge to ensuring it gets resolved. As TRAC tickets were developed, they were recorded in the status column.

\subsubsection{Importance and Feasibility Ratings}

The overall importance of each category was determined by assigning a 1-5 rating for (1) the frequency the comment came up and (2) the importance of the comment as it pertains to the completion of the webtool. The ratings were established using the guidelines as shown in the Table 1 below.

Table 1. Importance Ratings

\begin{tabular}{|l|l|}
\hline \multicolumn{2}{|c|}{ IMPORTANCE } \\
\hline \multicolumn{1}{|c|}{ Frequency } & \multicolumn{1}{c|}{ Importance of Comment } \\
\hline 1- only time comment came up & 1- pure opinion \\
2- repeated by someone & 2- opinion with foundation \\
3- comment has come up a few times & 3- would enhance tool \\
4- comment came up several times & 4- tool loses effectiveness without implementation \\
5- almost everyone mentioned it & 5- tool is incomplete without \\
\hline
\end{tabular}

The two subcategories were given a weighted average to attain the overall rating of importance. The frequency comments were made comprised $20 \%$ of the overall importance rating. The rating for the importance of the comment accounted for $80 \%$ of the overall importance. Although frequency is an important measure, it should not be weighted equally with importance because we had a very diverse set of reviewers. There may be a small frequency of comments from a particular constituency (e.g., retailers, utilities) that is inherently valuable due to the strategic importance of the stakeholder group. 
The feasibility of implementing each concern was determined by rating the (1) ease of implementing the solution, (2) the uncertainty and/or risk of its implementation, and (3) the time duration of the implementation. After each comment was rated in the applicable subcategories, the importance of each subcategory was considered and weighted in importance for determining the overall rating each comment attained in the main categories of importance and feasibility. The guide used to establish the ratings of the subcategories is detailed below.

Table 2. Feasibility Ratings.

\begin{tabular}{|l|l|l|}
\hline \multicolumn{2}{|c|}{ FEASIBILITY } \\
\hline \multicolumn{1}{|c|}{ Ease of Implementation } & \multicolumn{1}{|c|}{ Risk/Uncertainty } & \multicolumn{1}{c|}{ Duration } \\
\hline $\begin{array}{l}\text { 1- redoing all previous efforts } \\
\text { 2- extensive alterations/ } \\
\text { additions }\end{array}$ & 1- could increase liability & 1- years \\
3- substantial amount of work & benefits & 2- months \\
4- slightly involved change & 4- mill complicate things & 3- weeks \\
5- simple change & 5- practically no added risk & 4- days \\
\end{tabular}

The feasibility rating was established by weighting the importance of the subcategories. The ease of implementation and risk/uncertainty subcategories were each determined to represent $30 \%$ of the feasibility rating, and the duration category was weighted at $40 \%$.

Once the overall importance and feasibility ratings were determined the sorting tool was used to find comments of the greatest importance and feasibility. The PNNL team came to a consensus that the factors that comprised the final ratings in the main categories accurately portrayed the importance and feasibility of the tasks that needed to be completed in response to the peer review input.

\subsubsection{Overall Rankings, Short-term and Long-term Goals}

The importance and feasibility ratings were then weighted and summed to attain an overall ranking ranging from $0-50 .{ }^{2}$ There were two overall rankings, one for short-term goals that can reasonably be addressed before Lightfair and the release of Version 1.0 and another for long-term goals that will greatly enhance the tool but cannot be addressed immediately.

The set of short-term goals was weighted heavily by the feasibility of the task completion prior to Lightfair. The importance of the comment accounted for $40 \%$, while feasibility represented $60 \%$ of the short-term goal ranking. This weighting process still accounted for the importance of the comments, but brought less detrimental stylistic and agreement errors with higher feasibility to the top of the list. Examples of comments that attained higher short-term rankings than long-term rankings are (1) photometric images not showing, (2) making the strategy and control tabs more obvious, or (3) increasing the size of the vignette box so it is not necessary to scroll.

${ }^{2}$ The overall ranking was multiplied by 10 so that the range could be viewed as whole numbers rather than decimal points to better illustrate the variances. 
The long-term goal rankings were assigned a different weighting of the importance and feasibility ratings that put much more emphasis on the importance of the comments. In this case, feasibility accounted for $15 \%$ of the total, where importance was valued at $85 \%$. This process ensured that extremely important aspects of the webtool that are more difficult to implement such as (1) considering changes to vignette design, (2) adding additional vignettes, or (3) including additional space types were high on the list of priorities for the path forward post-Lightfair.

In consideration of timeline and resources, the overall ranking was reviewed to determine thresholds for practical resolution of the comments. All comments that were ranked above 40 in the short term had their actionable solutions made into tickets to be resolved. The practicality of resolving the comments that were between 35 and 39 was analyzed on an individual basis. All comments below the short term ranking of 35 were either established as "LT" for long term goals, or To Be Determined (TBD) for comments that did not have an obvious solution, but require additional considerations that will be worked through before Lightfair.

\subsubsection{Unrated Comments}

There were several comments that were either unrated, or have not been made into actionable ticket items yet. The reasons that comments have not been rated or set into motion to resolve are:

- Some ratings had a higher level of uncertainty because they needed additional research to determine the level of effort required to resolve the comment. Although the solutions to these comments might have a rating in the high 30's, the actual solution requires greater consideration than what could be established before the peer review report deadline. The status of these comments remains TBD.

- Comments that were made infrequently regarding the functionality of the webtool that we have been unable to replicate have a status TBD.

- Comments that expressed opinions, e.g. "perspectives are very helpful," or "tool is very intuitive and easy to use" were not rated at all, but included on a separate tab. There are $\sim 50$ comments that fall under this category.

- Positive comments were unrated and are contained in a separate list within the data set in Appendix E.

The numbered ratings were designed to be a guide and were not the sole factor driving prioritization. We viewed the ratings and threshold for comments to address analytically, and adjusted the comment priority accordingly. The final prioritization allows for modification from the ranking, but allows flexibility in establishing the ultimate viability of each action item.

\subsection{Recommendations}

\subsection{Development of Recommendations}

The spreadsheet and rating system proved to be very helpful tools in establishing reasonable goals for the short and long-term enhancements of the webtool. The organization of the spreadsheet has provided a straightforward range of recommendations for the improvements to the CLS that are clearly categorized and applicable.

At the completion of the rating process, all of the comments were ranked based on the assumptions and weighting factors indicated above into a list ranging from $0-50$. These overall

February 2009 
rankings provided guidance about which tasks can and should be the highest priorities for inclusion in the CLS Webtool version 1.0, scheduled for release at the Lightfair conference in New York City in May 2009.

\subsubsection{Prioritization Ranges}

For the purposes of prioritization, the following ranges were identified for A, B and C priorities:

- Comments ranked at 40 and above were considered highest (A) priority, and will be addressed using TRAC tickets for version 1.0.

- Comments in the range from 35-39 were considered high priority (B), and likely but not definitely achievable for version 1.0. A concerted best effort will be made to resolve comments in this range.

- Comments in the range from 30-34 were considered medium priority (C), and will only be addressed for version 1.0 if there is time after priorities A and B are completed.

- Comments in the range from 0-29 will be addressed in the next version of the software.

Most of the A priorities and many of the B priorities have already been turned into TRAC tickets as of the writing of this report (see Section 3.3 and Appendix E). The TRAC ticketing tool is a wiki-based list, and as such is dynamic and frequently changing as new information becomes available.

\subsubsection{Exceptions to Prioritization Ranges}

As noted above, the prioritization process was intended to serve as an overall sorting tool but in some cases will not serve to provide a definitive decision. There were a few comments arising from peer review input that were rated as having the highest importance and high difficulty. After discussion by the team it was agreed that several comments were going to be addressed in spite of the challenge level. These comments are considered necessary in order to achieve due diligence in responding to peer review comments in version 1.0. These exceptions are listed below.

- Add an "other space" category so users can enter parts of their building that are not included in the vignette offerings.

- Provide more detail in the Energy Summary about the impact of control strategies per vignette.

\subsection{Top Ten List of Priority Short-Term Recommendations}

Here is the list of the top ten most significant and relevant improvements that will be made within the webtool for version 1.0. These tasks may involve numerous smaller steps (TRAC tickets) to get to completion, but they are provided here in a more general summary format for clarity.

(1) Automatically select energy code based on user location.

(2) Move application into a new window after login to eliminate back button errors.

(3) Develop virtual screencast tour to provide introduction to webtool at the beginning of the process.

(4) Provide workflow guidance using help menu and step-by-step guidance at the key plan. 
(5) Increase the size of the vignette list pop-ups to reduce need for scrolling, and to ensure users can see the square footage input box.

(6) Provide more guidance on daylighting and controls, to help users understand more clearly the process of picking controls, how it is dealt with for energy analysis, and how to execute the strategies.

(7) Incorporate suggested text edits, fix database feeds (conditional logic) for missing graphics and resolve content errors.

(8) Create "How To Use This Packet" instructions in the implementation packet, and improve formatting and layout.

(9) Add more detail about energy consumption in the Energy Summary (e.g., kWh per vignette).

(10) Add an "other space" category so users can enter parts of their building that are not included in the vignette offerings.

\subsection{TRAC Tickets}

For the purposes of comprehensive reporting, the TRAC ticket list has been exported into a chart format and shown with A and B priorities in Appendix D.

\subsection{Peer Review Input Data}

The master spreadsheet containing all of the peer review input is contained in Appendix E.

\subsection{List of Long-Term Priority Recommendations}

As expected, there are a number of recommendations considered to be high priority by the reviewers and by PNNL but are too ambitious to be completed for Version 1.0. Below is a list of tasks for consideration for the next version of the webtool.

\begin{tabular}{|l|l|}
\hline \multicolumn{1}{|c|}{ Long Term Goals } & Reason for the Long Term Nature of the Goal \\
\hline $\begin{array}{l}\text { Add Title 24 and CBECS baselines into the } \\
\text { tool, so the webtool can be available to } \\
\text { California users and organizations that have } \\
\text { committed to the Architecture 2030 goals. }\end{array}$ & $\begin{array}{l}\text { Since these baselines allow for multiple means of } \\
\text { compliance including them as baselines will } \\
\text { require more involved energy analysis. }\end{array}$ \\
\hline $\begin{array}{l}\text { Increase the diversity of the designs and } \\
\text { building types to cover more of the REA } \\
\text { members' needs and to increase applicability } \\
\text { to those utilities who want to use CLS in their } \\
\text { rebate and incentive programs. }\end{array}$ & $\begin{array}{l}\text { Additional designs will require lighting designers } \\
\text { to be subcontracted, and integrating any new } \\
\text { vignettes or building types will be a substantial } \\
\text { amount of work. }\end{array}$ \\
\hline
\end{tabular}




\begin{tabular}{|l|l|}
\hline $\begin{array}{l}\text { Add the project data collection interface to the } \\
\text { tool so the energy savings estimate can be } \\
\text { made more accurate as design and contract } \\
\text { documents are generated and so utilities can } \\
\text { use the output for incentive submittals. }\end{array}$ & $\begin{array}{l}\text { Including the data collection interface is a } \\
\text { substantial software development effort and } \\
\text { needs to be done with the intention of connecting } \\
\text { to compliance tools. }\end{array}$ \\
\hline $\begin{array}{l}\text { Find a way to address economic and/or } \\
\text { payback considerations. }\end{array}$ & $\begin{array}{l}\text { A lighting technology database that is capable of } \\
\text { reflecting costs varying by location and project } \\
\text { scope will be necessary before a meaningful } \\
\text { economic analysis can be applied to the designs. } \\
\text { There is a large margin of variability and this is a } \\
\text { time intensive task. }\end{array}$ \\
\hline $\begin{array}{l}\text { Implement a content management system with } \\
\text { a mechanism to streamline new content and } \\
\text { manage internal and external review. }\end{array}$ & $\begin{array}{l}\text { As the content in the webtool increases a new } \\
\text { system needs to be established to facilitate } \\
\text { content management. Research must be done to } \\
\text { ensure that the system chosen will provide the } \\
\text { desired solutions. }\end{array}$ \\
\hline $\begin{array}{l}\text { Expand energy summary to include HVAC } \\
\text { impact as affected by various lighting } \\
\text { strategies. }\end{array}$ & $\begin{array}{l}\text { Whole building energy simulation models will } \\
\text { need to be run in all of the climate zones with } \\
\text { daylighting aperture recommendations in mind. }\end{array}$ \\
\hline $\begin{array}{l}\text { Provide additional guidance on Daylighting } \\
\text { envelope design for various climates. }\end{array}$ & $\begin{array}{l}\text { There is currently no party that provides this type } \\
\text { of comprehensive instruction for a specific } \\
\text { building type. Numerous research papers will } \\
\text { have to be applied by an expert in the field. }\end{array}$ \\
\hline
\end{tabular}

\subsection{Conclusion}

The peer review data collection process was effective in gathering sufficient input from the appropriate range of stakeholders in a way that allowed for a meaningful understanding of the issues and useful ideas about improvements. The data analysis and prioritization process was thorough and efficient, yielding reasonable goals and a clear path forward. The master spreadsheet will continue to be used as a tool as appropriate throughout the resolution of comments, and will be an effective tool for future peer reviews. PNNL plans to use the peer review input, in both the near and long-term, to improve the value of the CLS webtool. 


\section{Appendix A: Reviewer List}

\begin{tabular}{|c|c|c|c|}
\hline Category & First name & Last Name & Contact Information \\
\hline \multicolumn{4}{|c|}{ External Reviewers } \\
\hline \multicolumn{4}{|c|}{$\begin{array}{l}\text { Categories: Engineer, Lighting Designer, Manufacturer, Retailer, State, Utility, Energy Efficiency Program Sponso } \\
\text { (EEPS), Core Team }\end{array}$} \\
\hline Core Team & Barb & Hamilton & $\begin{array}{l}\text { New Buildings Institute } \\
509-493-4468, \text { x } 15 \text { office } \\
503-704-8870 \text { cell }\end{array}$ \\
\hline EEPS & Jon & Linn & $\begin{array}{l}\text { Northeast Energy Efficiency Partnerships } \\
\text { Belfast, ME } 04915 \\
\text { 207-338-9705 office }\end{array}$ \\
\hline Engineer & Tate & Betz & $\begin{array}{l}\text { Henderson Engineers, Inc. } \\
\text { Lenexa, KS } 66214 \\
913-742-5676 \text { office }\end{array}$ \\
\hline Engineer & Lisa & Coyan & $\begin{array}{l}\text { Henderson Engineers, Inc. } \\
\text { Lenexa, Kansas } 66214 \\
913-742-5347 \text { office }\end{array}$ \\
\hline Engineer & Nick & Ferzacca & $\begin{array}{l}\text { Architectural Engineers, Inc. } \\
\text { Boston, MA } 02110 \\
617-542-0810 \times 111 \text { phone }\end{array}$ \\
\hline Engineer & Nick & Gordon & $\begin{array}{l}\text { Henderson Engineers, Inc. } \\
\text { Lenexa, Kansas } 66214 \\
913-742-5300 \text { office }\end{array}$ \\
\hline Engineer & Mark & Hershman & $\begin{array}{l}\text { Henderson Engineers, Inc. } \\
\text { Lenexa, Kansas } 66214 \\
913-742-5347 \text { office }\end{array}$ \\
\hline Engineer & Brandon & Manning & $\begin{array}{l}\text { Henderson Engineers, Inc. } \\
\text { Lenexa, Kansas } 66214 \\
913-742-5345 \text { office }\end{array}$ \\
\hline Engineer & Julie & Pierce & $\begin{array}{l}\text { Henderson Engineers, Inc. } \\
\text { Lenexa, Kansas } 66214 \\
913-742-5360 \text { office }\end{array}$ \\
\hline $\begin{array}{l}\text { Lighting } \\
\text { Designer }\end{array}$ & Kathy & Abernathy $^{3}$ & $\begin{array}{l}\text { Abernathy Lighting Design, Inc. } \\
\text { N. Providence RI } 02911 \\
401-233-4412 \text { office }\end{array}$ \\
\hline
\end{tabular}

\footnotetext{
${ }^{3}$ Chairperson, IALD Energy and Sustainability Committee.
} 


\begin{tabular}{|c|c|c|c|}
\hline Category & First name & Last Name & Contact Information \\
\hline $\begin{array}{l}\text { Lighting } \\
\text { Designer }\end{array}$ & Jim & Benya & $\begin{array}{l}\text { Benya Lighting Design } \\
\text { West Linn, OR } 07086 \\
\text { 503-657-9157 office }\end{array}$ \\
\hline $\begin{array}{l}\text { Lighting } \\
\text { Designer }\end{array}$ & Leslie & Davis & $\begin{array}{l}\text { Leslie Davis Lighting } \\
\text { California } \\
510-798-8635 \text { cell }\end{array}$ \\
\hline $\begin{array}{l}\text { Lighting } \\
\text { Designer }\end{array}$ & Hayden & McKay & $\begin{array}{l}\text { HLB Lighting Design } \\
\text { New York, NY } 10003 \\
212-674-5580, \text { x } 133 \text { office }\end{array}$ \\
\hline $\begin{array}{l}\text { Lighting } \\
\text { Designer }\end{array}$ & Naomi & Miller & $\begin{array}{l}\text { Naomi Miller Lighting Design } \\
\text { Troy, NY } 12180 \\
518-272-2745 \text { office }\end{array}$ \\
\hline Manufacturer & Greg & Subisak $^{4}$ & $\begin{array}{l}\text { Holophane } \\
\text { Granville, OH } \\
\text { 740-349-4798 office }\end{array}$ \\
\hline Manufacturer & Craig & Dilouie & $\begin{array}{l}\text { Zing Communications } \\
\text { Calgary, AB T2T 0C8 } \\
403-802-1809 \text { office }\end{array}$ \\
\hline Retailer & David & DeVos & $\begin{array}{l}\text { Kohl's } \\
\text { Menomonee Falls, WI } 53051 \\
\text { 262-703-2058 office }\end{array}$ \\
\hline Retailer & Amy & Laughead & Macy's \\
\hline Retailer & Bill & Lyon & $\begin{array}{l}\text { Macy's } \\
\text { Duluth, GA }\end{array}$ \\
\hline Retailer & David & Oshinski & $\begin{array}{l}\text { Home Depot } \\
\text { Atlanta, GA } 30303 \\
\text { 770-384-4139 office }\end{array}$ \\
\hline Retailer & Seth & Stutzman & $\begin{array}{l}\text { Whole Foods } \\
\text { TX } \\
512-413-4229 \text { cell }\end{array}$ \\
\hline Retailer & Scott & Williams & $\begin{array}{l}\text { Target } \\
\text { Minneapolis, MN } \\
612-761-1623 \text { office }\end{array}$ \\
\hline
\end{tabular}

${ }^{4}$ Chairperson, IESNA Retail Applications Committee.

February 2009

Page A-2 


\begin{tabular}{|c|c|c|c|}
\hline Category & First name & Last Name & Contact Information \\
\hline Retailer & Ralph & Williams & $\begin{array}{l}\text { Wal-Mart } \\
\text { Bentonville, AR 72716-0550 } \\
479-273-4279 \text { office }\end{array}$ \\
\hline State & Vance & Barr & $\begin{array}{l}\text { NYSDPS } \\
\text { New York State Dept of Public Service, OEEE } \\
\text { Albany, NY 12223 } \\
\text { Floyd Barwig: 518-474-5368 office }\end{array}$ \\
\hline State & Marilyn & Dare & $\begin{array}{l}\text { NYSERDA } \\
\text { Albany, NY } 12203 \\
518-862-1090, \text { x3348 office }\end{array}$ \\
\hline Utility & Gabe & Arnold & $\begin{array}{l}\text { Efficiency Vermont } \\
\text { Burlington, VT } 05401 \\
802-658-6060 \text { x } 1085 \text { office }\end{array}$ \\
\hline Utility & Fran & Boucher & $\begin{array}{l}\text { National Grid } \\
\text { Waltham, MA } 02451 \\
617-620-1825 \text { cell }\end{array}$ \\
\hline Utility & Tom & Coughlin & $\begin{array}{l}\text { National Grid } \\
\text { Waltham, MA } 02451 \\
781-907-1582 \text { office }\end{array}$ \\
\hline Utility & Michael & McAteer & $\begin{array}{l}\text { National Grid } \\
\text { Northboro, MA } 01532 \\
508-303-7225 \text { office }\end{array}$ \\
\hline \multicolumn{4}{|c|}{ Internal Reviewers } \\
\hline Internal Team & Rosemarie & Bartlett & $\begin{array}{l}\text { PNNL } \\
\text { Richland, WA } 99352 \text { USA } \\
\text { 509-375-6606 office }\end{array}$ \\
\hline Internal Team & Sean & McDonald & $\begin{array}{l}\text { PNNL } \\
\text { Washington, DC } \\
\text { 202-646-5226 office }\end{array}$ \\
\hline Internal Team & Jason & Tuenge & $\begin{array}{l}\text { PNNL } \\
\text { Richland, WA } 99352 \\
\text { 503-417-7541 office }\end{array}$ \\
\hline
\end{tabular}




\section{Appendix B: Webtool Page Reference File}

\section{NOTE TO REVIEWERS:}

THANK YOU for taking the time to give us feedback on the Beta version of the Commercial Lighting Solutions webtool. We have provided a separate spreadsheet form for your use in capturing your comments (file name "CLS Spreadsheet Input Form (1-09).xls"). In order for our team to process your comment, we need to locate it within the tool. Where applicable, please help us by listing both the store type (e.g., Grocery, Pharmacy) as well as a reference webpage location name. Below you will see examples of names for the various pages within the tool.

Sincerely,

The Commercial Lighting Solutions Team

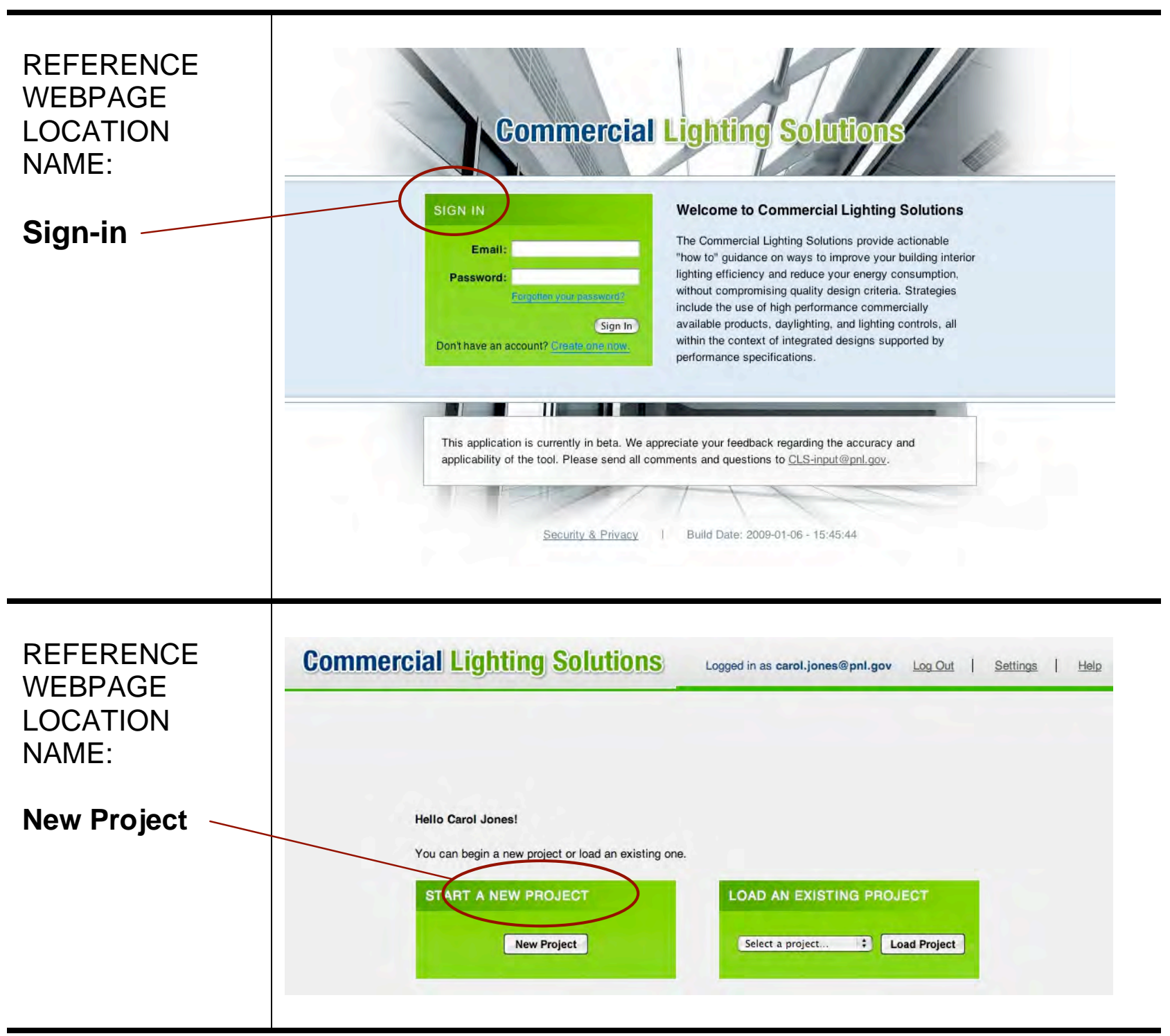


Reference Webpage Locations Names, for CLS Peer Review Input Form

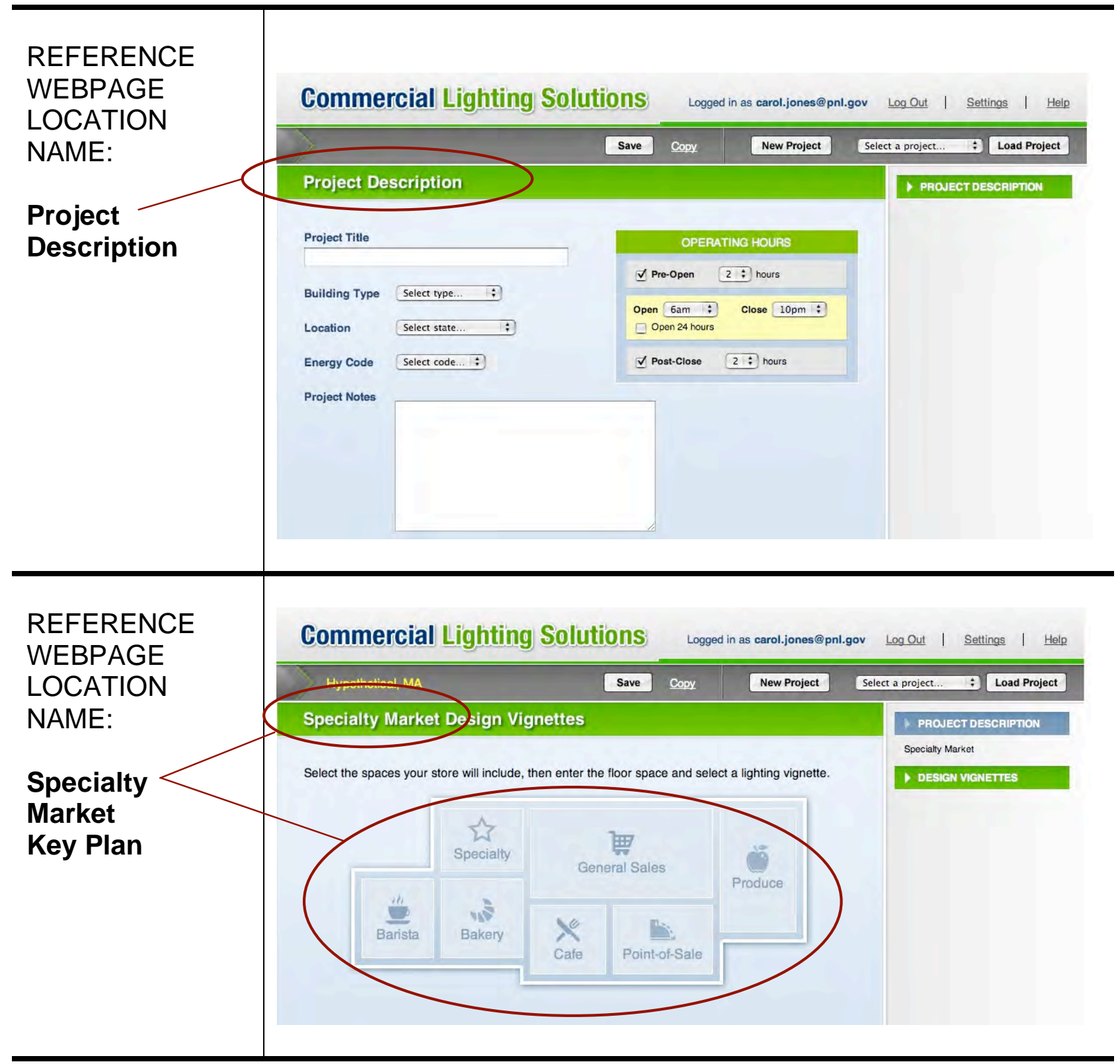


Reference Webpage Locations Names, for CLS Peer Review Input Form

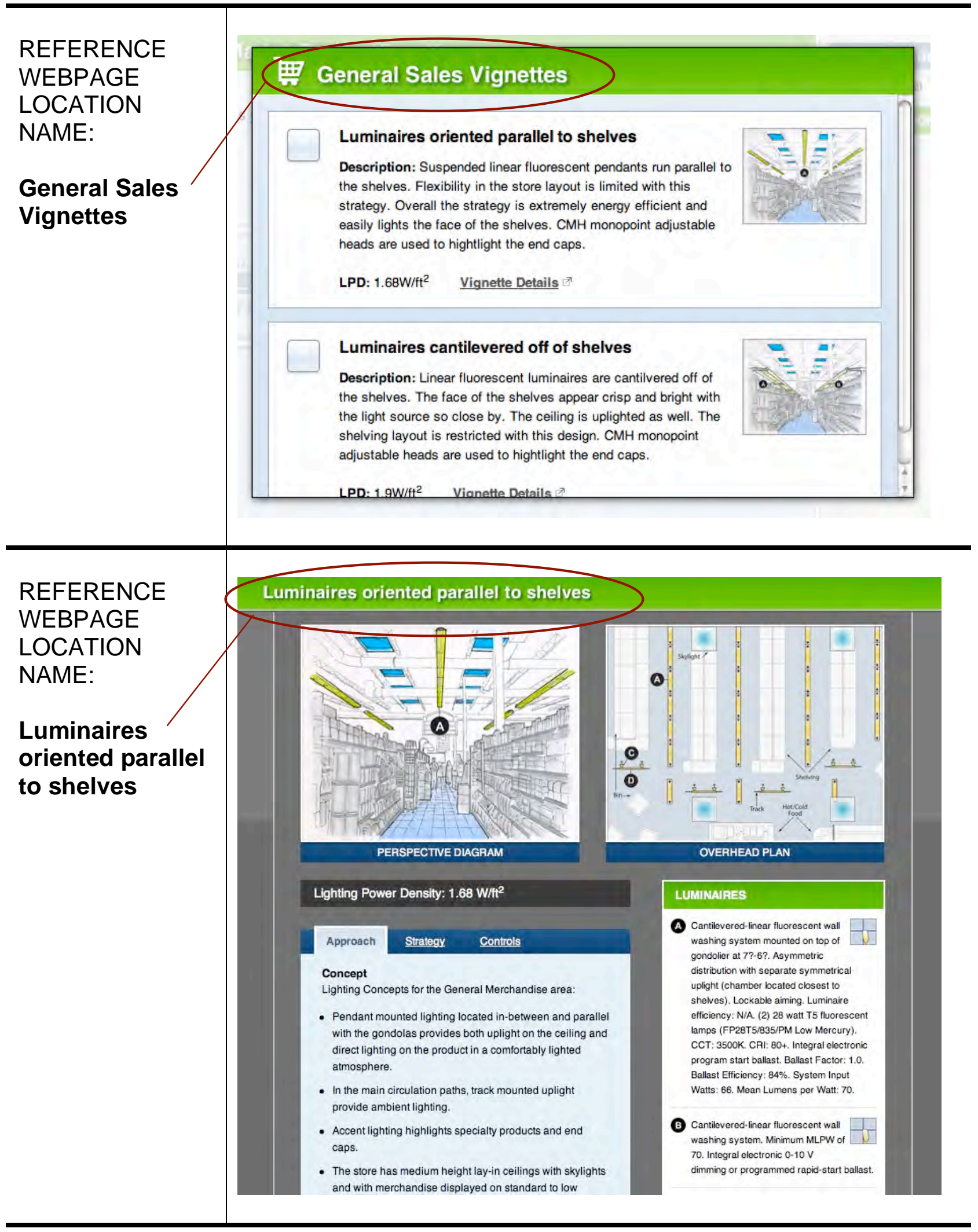


Reference Webpage Locations Names, for CLS Peer Review Input Form

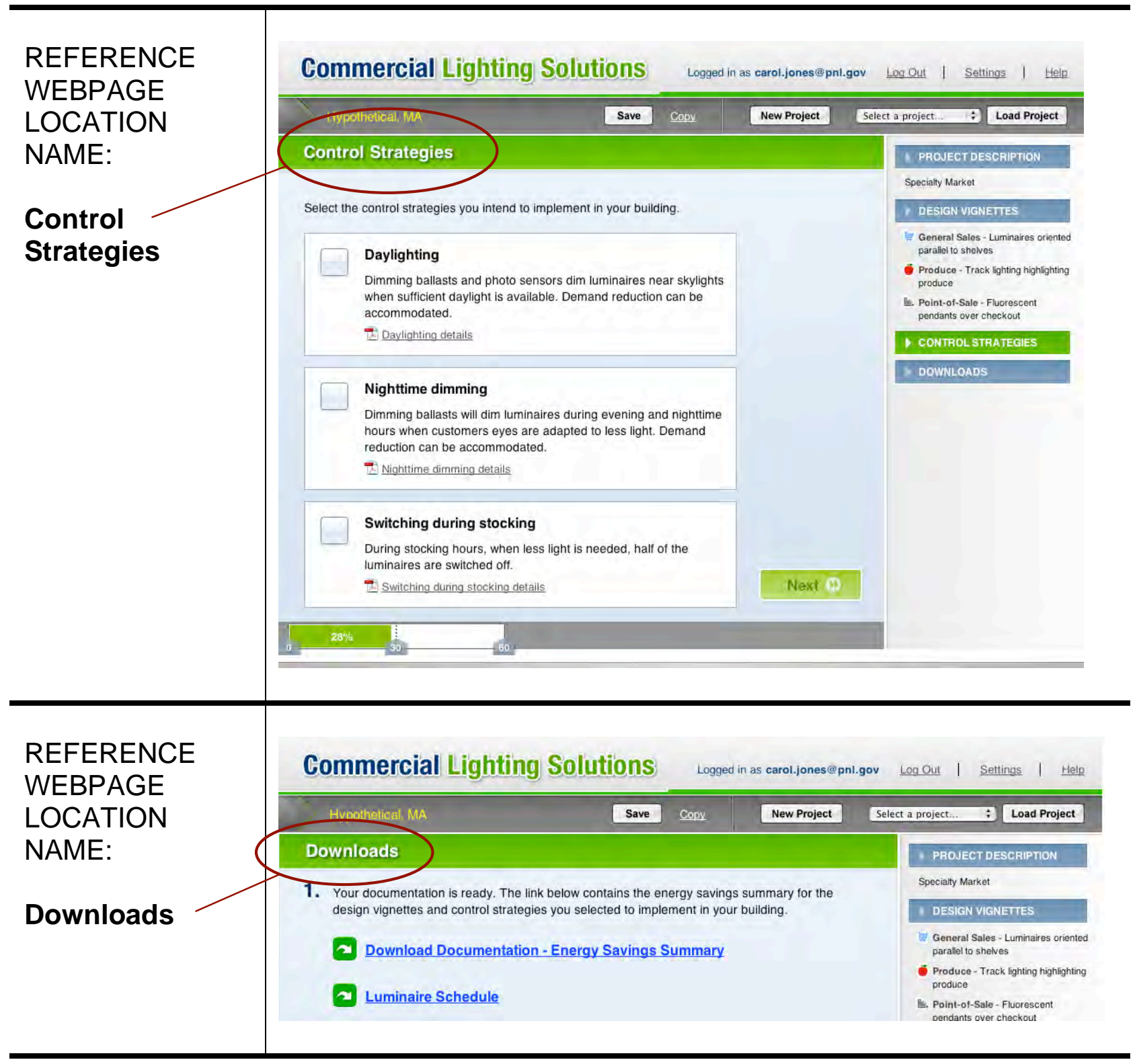




\section{Appendix C: Peer Review Input Spreadsheet}

Commercial Lighting Solutions, Peer Review Input Form

\begin{tabular}{|l|}
\hline Date: \\
\hline Commenter Name: \\
\hline Organization Name: \\
\hline Mac or PC: \\
\hline Operating System: \\
\hline Browser \& Version \#: \\
\hline
\end{tabular}

COMMENT TYPES / QUESTIONS

Functionality: Does the tool work the way it's supposed to? Are there bugs, problems?

Appearance/Aesthetics: Do you like the way it looks?

Content: Do you like the content of the tool, including designs, text descriptions, graphics, luminaire chart, etc?

Ease of Use/Flow: Does the webtool lead you through the process well? Is it intuitive?

Download Materials: Do you have feedback about the Energy Summary, Vignette Summaries and Implemenation Instructions or Luminaire Schedule?

General: Do you have any comments that apply to the whole tool or defy categorization?

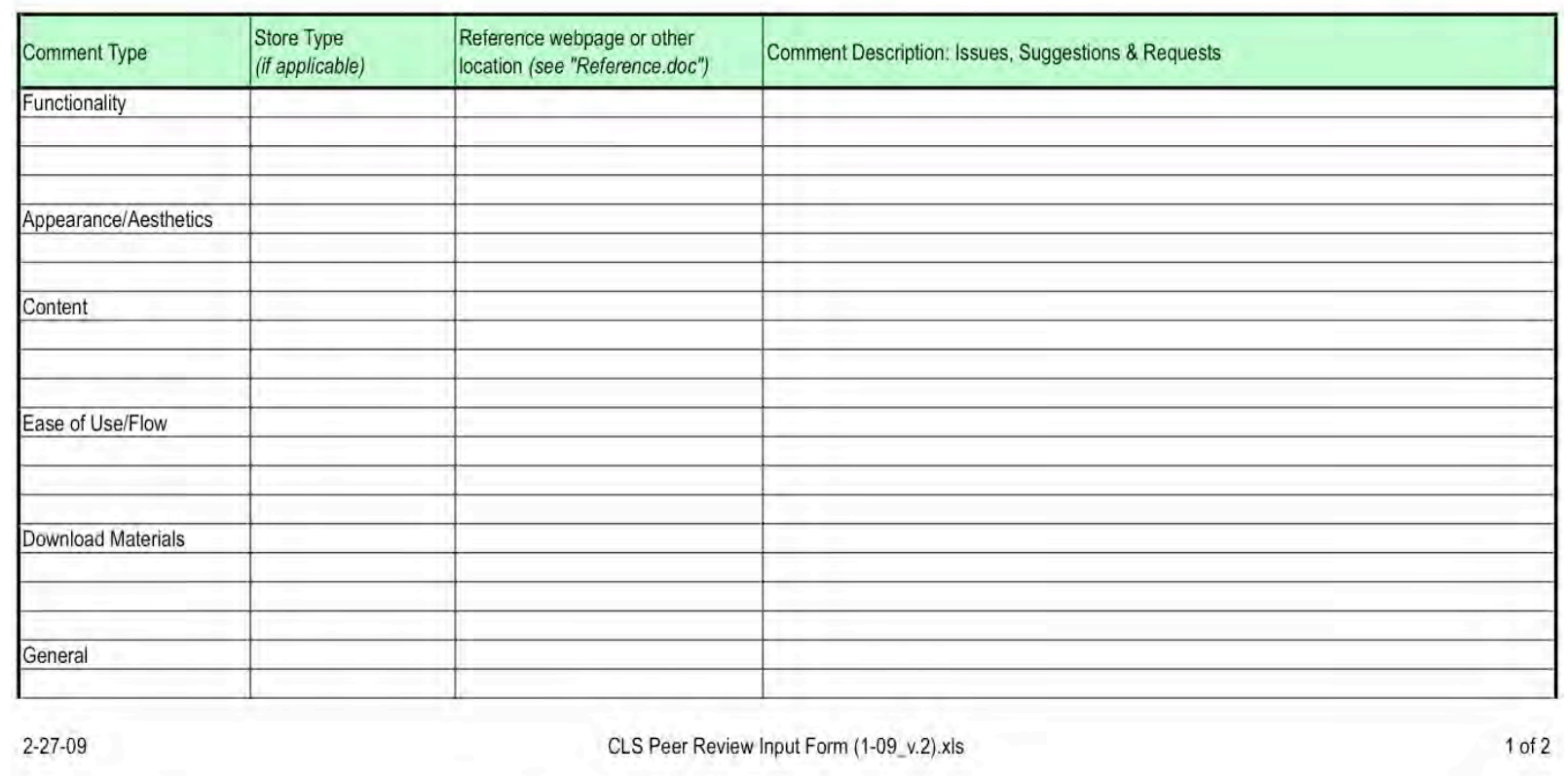




\section{Appendix D: TRAC Ticket List}

\begin{tabular}{|c|c|c|c|}
\hline TICKET \# & PRIORITY & SUMMARY & DESCRIPTION \\
\hline 76 & A & $\begin{array}{l}\text { Vignettes } \\
\text { descriptions_global } \\
\text { formatting problem_- } \\
\text { unintended hard } \\
\text { return }\end{array}$ & $\begin{array}{l}\text { Example: Discount Big Box. General - } \\
\text { Perpendicular } 21 \text { - Approach tab. The text } \\
\text { "...temperature: } 3000 \mathrm{~K} 3500 \mathrm{~K} \text { " is broken into } \\
\text { two bullet points. (Typical of others.) Another } \\
\text { example is: The text "...displayed on } 8-0 \text { height } \\
\text { gondolas" is broken into three bullet points. }\end{array}$ \\
\hline 68 & A & $\begin{array}{l}\text { Vignette } \\
\text { Implementation } \\
\text { header isn't indented. }\end{array}$ & \\
\hline 51 & A & $\begin{array}{l}\text { Add contextual help } \\
\text { to define Building } \\
\text { Types }\end{array}$ & $\begin{array}{l}\text { Add a '?' link which points to a detailed } \\
\text { description of the building types and how the } \\
\text { labels apply to actual store types. Just links to } \\
\text { an anchor in the main Help page. }\end{array}$ \\
\hline 35 & A & $\begin{array}{l}\text { Move application into } \\
\text { a new window } \\
\text { without browser } \\
\text { toolbar after login }\end{array}$ & $\begin{array}{l}\text { Several users have mentioned problems with the } \\
\text { application when they hit the back button. } \\
\text { Refactoring the app to utilize the back button is } \\
\text { not an option at the moment_so we should } \\
\text { remove the temptation to use the button by } \\
\text { moving the user into a new window after they } \\
\text { log in. COMcheckWeb and REScheckWeb } \\
\text { have used this strategy successfully. }\end{array}$ \\
\hline 109 & A & $\begin{array}{l}\text { Double check validity } \\
\text { of illuminance } \\
\text { criteria }\end{array}$ & $\begin{array}{l}\text { the max \& min would result in different w/sf } \\
\text { solutions; state what this means (ave } \\
\text { maintained_initial_max-min for a mid } \\
\text { range?)_100-150 FC may damage produce (cmh } \\
\text { downlights over oranges display in local market } \\
\text { caused fruit to warm - customers don't want to } \\
\text { buy warm fruit or produce. }\end{array}$ \\
\hline 22 & A & $\begin{array}{l}\text { Create a Control } \\
\text { Strategy Detail page - } \\
\text { front end }\end{array}$ & $\begin{array}{l}\text { A new page similar to vignette details that } \\
\text { would get rid of the control strategies details } \\
\text { PDF. }\end{array}$ \\
\hline
\end{tabular}




\begin{tabular}{|c|c|c|c|}
\hline TICKET \# & PRIORITY & SUMMARY & DESCRIPTION \\
\hline 25 & A & $\begin{array}{l}\text { Luminaire Schedule - } \\
\text { handle } \\
\text { dimming/switching }\end{array}$ & $\begin{array}{l}\text { Change Nighttime dimming description from } \\
\text { "Non-daylight dimming" to "Dim electric } \\
\text { lighting to accommodate nighttime visual } \\
\text { adaptation level._Change "Occupancy Sensors" } \\
\text { description from "Occupancy Sensors" to "Dim } \\
\text { or switch electric lighting when associated areas } \\
\text { are vacant_Nightime dimming shows up under } \\
\text { Control Strategy but was not selected; I revised } \\
\text { one area to include daylight dimming \& } \\
\text { nightime dimming still shows up. }\end{array}$ \\
\hline 60 & A & $\begin{array}{l}\text { Improve Control } \\
\text { descriptions to } \\
\text { include operating } \\
\text { hours and applicable } \\
\text { spaces }\end{array}$ & $\begin{array}{l}\text { Makes perfect sense. Straightforward } \\
\text { information. I wonder though_ since I chose } \\
\text { "Switching during Stocking" -- it does not } \\
\text { reiterate WHAT has been applied for this } \\
\text { choice. I assume that whatever savings have } \\
\text { been calculated with info from the opening } \\
\text { screen (identifier of open hrs_pre-post open } \\
\text { hours) --- shouldn't there be a } \\
\text { reminder/clarification in the Savings Discussion } \\
\text { of the assumptions? (Such as "Half the fixtures } \\
\text { turned off entirely for a total of } 4 \text { operating } \\
\text { hours.") }\end{array}$ \\
\hline 71 & A & $\begin{array}{l}\text { Imrpove login box so } \\
\text { that "Register" link is } \\
\text { obvious }\end{array}$ & $\begin{array}{l}\text { Users seem to need a little more obvious } \\
\text { Register link_to make sure they know they } \\
\text { need to do so. }\end{array}$ \\
\hline 64 & A & $\begin{array}{l}\text { Add Building Type to } \\
\text { Vignette Details page }\end{array}$ & \\
\hline 58 & A & $\begin{array}{l}\text { Location selection } \\
\text { defect }\end{array}$ & $\begin{array}{l}\text { selecting a project location from the drop-down } \\
\text { boxes present_the selection consistently misses } \\
\text { my choice. } \neg \nmid \text { Selecting New York repeatedly } \\
\text { gave me North Carolina and the other drop- } \\
\text { down box selections made similar mis-direction } \\
\text { errors. } \neg \dagger \neg \dagger\end{array}$ \\
\hline 111 & A & $\begin{array}{l}\text { Reconsider CCT } \\
\text { Range }\end{array}$ & $\begin{array}{l}\text { Are we sure that we want to limit users to a max } \\
\text { of } 3500 \mathrm{~K} \text { ? } 4100 \mathrm{~K} \text { looks good with daylight__ } \\
\text { and most of these designs have } \\
\text { skylights_Expand the color range to } 4100 \mathrm{~K}\end{array}$ \\
\hline 52 & A & $\begin{array}{l}\text { Add contextual help } \\
\text { to Hours of Operation } \\
\text { to define terms }\end{array}$ & $\begin{array}{l}\text { Add a '?' link to Help with definitions of "Pre- } \\
\text { open" and "Post-open" }\end{array}$ \\
\hline
\end{tabular}




\begin{tabular}{|c|c|c|c|}
\hline TICKET \# & PRIORITY & SUMMARY & DESCRIPTION \\
\hline 63 & A & $\begin{array}{l}\text { Recommend having } \\
\text { the report download } \\
\text { link include a PDF } \\
\text { icon so you know it's } \\
\text { a PDF you're getting. }\end{array}$ & \\
\hline 91 & A & $\begin{array}{l}\text { Provide guidance for } \\
\text { users to find products } \\
\text { to implement their } \\
\text { designs }\end{array}$ & $\begin{array}{l}\text { From the luminaire schedule_ how can a user } \\
\text { get to where they can specify a product? There } \\
\text { needs to be a user-friendly translation of the } \\
\text { generic specs to a project fixture schedule with } \\
\text { catogue information_How do you address } \\
\text { product quality? That is - making sure you are } \\
\text { comparing equal products_Luminaire schedule } \\
\text { has a lot of good information - still leary of } \\
\text { overall product description as it relates to } \\
\text { quality. }\end{array}$ \\
\hline 97 & A & $\begin{array}{l}\text { Clarify lighting } \\
\text { inputs_limitations of } \\
\text { tool_etc. }\end{array}$ & $\begin{array}{l}\text { Clarify if or how stock room lighting is } \\
\text { entered_Clarify if or how offices_break rooms } \\
\text { or other back-of-house lighting is } \\
\text { entered_Clarify if or how sub let lease spaces } \\
\text { such as bank tenants lighting is entered_LPD } \\
\text { guidelines for design options are helpful tools to } \\
\text { utilize for budgeting the lighting design at the } \\
\text { beginning of a project - but tool should not be } \\
\text { used as the full "recipe" to design various } \\
\text { spaces. Need to be clear that these are estimates } \\
\text { and intent is to make end-use aware of issues_In } \\
\text { Energy Summary-- put in a note that this does } \\
\text { not account for AC etc. }\end{array}$ \\
\hline 75 & A & Text content edits & $\begin{array}{l}\text { Text edits on vignette descriptions_ vignette } \\
\text { summaries_luminaire descriptions_control } \\
\text { strategies_and titles. }\end{array}$ \\
\hline 90 & A & $\begin{array}{l}\text { Adjustments to } \\
\text { perspective drawings }\end{array}$ & $\begin{array}{l}\text { Incorrect luminaire housing or placement } \\
\text { indicated in perspective_grid } \\
\text { agreement_skylight agreement__ }\end{array}$ \\
\hline
\end{tabular}




\begin{tabular}{|c|c|c|c|}
\hline TICKET \# & PRIORITY & SUMMARY & DESCRIPTION \\
\hline 96 & A & $\begin{array}{l}\text { Clarify (range of) } \\
\text { mounting heights } \\
\text { in/before vignette } \\
\text { choice }\end{array}$ & $\begin{array}{l}\text { Find a way to describe your representative type } \\
\text { of building way back at the project description } \\
\text { page. Building type descriptions?_Vignette } \\
\text { Implementation is good_required assumptions } \\
\& \text { dimensions are noted. Would like to see a } \\
\text { reference to this section earlier on - took me } \\
\text { awhile to find this_there is no reference } \\
\text { anywhere regarding the issue of mounting } \\
\text { heights }\end{array}$ \\
\hline 70 & A & $\begin{array}{l}\text { Do NOT allow } \\
\text { duplicate project } \\
\text { titles }\end{array}$ & \\
\hline 113 & A & $\begin{array}{l}\text { Empty sections in } \\
\text { download material } \\
\text { should be omitted }\end{array}$ & $\begin{array}{l}\text { null text should not be displayed, e.g. project } \\
\text { name and quick tips (the latter subject should } \\
\text { not appear at all if empty) }\end{array}$ \\
\hline 104 & A & $\begin{array}{l}\text { Ballast/wiring } \\
\text { agreement for } \\
\text { dimming in control } \\
\text { tab/vignette }\end{array}$ & $\begin{array}{l}\text { Luminaires A - describes dimming ballast but I } \\
\text { did not choose a dimming option_Dimming } \\
\text { recommended but types A and B aren't } \\
\text { dimmable_General Notes on ballasts are not } \\
\text { consistent with the ballasts used in the vignette- } \\
\text { no information about the dimming ballasts }\end{array}$ \\
\hline 85 & A & $\begin{array}{l}\text { Remove link to } \\
\text { example } \\
\text { documentation on } \\
\text { download page }\end{array}$ & $\begin{array}{l}\text { From commenter: Perhaps you should get rid of } \\
\text { the example documentation now? It shows up } \\
\text { before the download links and says that the } \\
\text { documentation is not related to the vignettes that } \\
\text { you pick. This creates disappointment even } \\
\text { though in reality the custom documentation is } \\
\text { loading to the links. }\end{array}$ \\
\hline 37 & A & $\begin{array}{l}\text { Vignette images } \\
\text { should be } \\
\text { larger/expandable }\end{array}$ & $\begin{array}{l}\text { Users would like to see a higher-res version of } \\
\text { the vignette images. I assume they mean from } \\
\text { the Vignette Details page: a click on the } \\
\text { thumbnail in the dialog will get them more info. } \\
\text { We can implement a "lightbox" feature that uses } \\
\text { the high-res versions of the images so that users } \\
\text { can see more detail before selecting the } \\
\text { vignette. }\end{array}$ \\
\hline 89 & A & $\begin{array}{l}\text { Strategy and Controls } \\
\text { tabs should be more } \\
\text { obvious }\end{array}$ & $\begin{array}{l}\text { Commenter: "It wasn't obvious to me that I } \\
\text { should also hit the strategy and controls tabs. } \\
\text { There is very important information there_ is } \\
\text { there a way to make it more obvious? Maybe } \\
\text { buttons instead of tabs? Or numbering them?" }\end{array}$ \\
\hline
\end{tabular}




\begin{tabular}{|c|c|c|c|}
\hline TICKET \# & PRIORITY & SUMMARY & DESCRIPTION \\
\hline 45 & A & $\begin{array}{l}\text { Downloads page } \\
\text { should better reflect } \\
\text { the user has reached } \\
\text { an endpoint }\end{array}$ & $\begin{array}{l}\text { Users don't feel any sense of accomplishment } \\
\text { when they reach the Downloads page. They } \\
\text { aren't sure what they're getting_or if they're } \\
\text { done. We need to make it clearer that these files } \\
\text { are the end result of the application (at least for } \\
\text { Phase 1). }\end{array}$ \\
\hline 49 & A & $\begin{array}{l}\text { Selected vignette is } \\
\text { not always visible } \\
\text { when the dialog } \\
\text { opens }\end{array}$ & $\begin{array}{l}\text { If you click on a space with a stored vignette } \\
\text { and there happen to be multiple choices } \\
\text { available_there's no guarantee that the vignette } \\
\text { you chose will be visible when the dialog opens. } \\
\text { The dialog should be automatically scrolled to } \\
\text { that vignette when the dialog opens_ with the } \\
\text { area input visible. }\end{array}$ \\
\hline 83 & A & $\begin{array}{l}\text { Make a "How to use } \\
\text { this packet" for } \\
\text { Implementation } \\
\text { Instructions }\end{array}$ & $\begin{array}{l}\text { From commenter: An explanation is needed } \\
\text { about why the luminaire labels have changed } \\
\text { from A_B_C to RMC1s_etc. Perhaps a letter } \\
\text { in-between the summaries and implementation } \\
\text { guidance? Or a summary of the contents of the } \\
\text { packet at the beginning? Maybe a "how to use } \\
\text { this info" added to the introduction. }\end{array}$ \\
\hline 79 & A & $\begin{array}{l}\text { Anaylze nighttime } \\
\text { dimming calculations } \\
\text { with Mike }\end{array}$ & $\begin{array}{l}\text { Nighttime dimming doesn't seem to be } \\
\text { calculating properly. Need to define some use } \\
\text { cases and analyze the calculations with Mike. }\end{array}$ \\
\hline 115 & A & $\begin{array}{l}\text { General Formatting } \\
\text { Issues }\end{array}$ & $\begin{array}{l}\text { Database not feeding to vignettes, no vignette } \\
\text { description, gray background inconsistent }\end{array}$ \\
\hline 88 & A & $\begin{array}{l}\text { Technical details } \\
\text { and/or labels are not } \\
\text { in agreement }\end{array}$ & $\begin{array}{l}\text { Erroneous descriptions_photometric curves that } \\
\text { don't sync with distributions_A/B/C labels that } \\
\text { don't match_lamp descriptions that don't } \\
\text { match_descriptions for wrong luminaires. }\end{array}$ \\
\hline 43 & A & $\begin{array}{l}\text { No way to close the } \\
\text { Vignette dialog } \\
\text { without selecting a } \\
\text { Vignette }\end{array}$ & $\begin{array}{l}\text { When we moved the dialog footer to be } \\
\text { associated with the Vignette box we removed } \\
\text { any ability for the user to close the dialog } \\
\text { ("Cancel" operation) without first selecting a } \\
\text { Vignette. We might consider moving the } \\
\text { "OK" and "Cancel" buttons back out into a } \\
\text { footer area. }\end{array}$ \\
\hline 78 & A & $\begin{array}{l}\text { Text content under } \\
\text { approach/strategy is } \\
\text { sometimes missing }\end{array}$ & $\begin{array}{l}\text { Look under "missing" category to find details } \\
\text { about where things are missing. }\end{array}$ \\
\hline
\end{tabular}




\begin{tabular}{|c|c|c|c|}
\hline TICKET \# & PRIORITY & SUMMARY & DESCRIPTION \\
\hline 95 & A & $\begin{array}{l}\text { Provide more } \\
\text { maintenance } \\
\text { information on } \\
\text { vignette pages and } \\
\text { energy summary }\end{array}$ & $\begin{array}{l}\text { Maintenance issues are a nice addition - need to } \\
\text { elaborate_The Vignette Summary "Maintenance } \\
\text { Issues" section should be more descriptive } \\
\text { regarding cleaning of luminaires. A "damp rag" } \\
\text { is vague. A note should be added to consult } \\
\text { manufacturer guidelines for cleaning to ensure } \\
\text { fixture longevity and maintain warranties. }\end{array}$ \\
\hline 107 & A & $\begin{array}{l}\text { Provide additional } \\
\text { design input }\end{array}$ & $\begin{array}{l}\text { There doesn't seem to be consideration given to } \\
\text { other daylighting strategies like interior } \\
\text { reflective surfaces and variable shelving/display } \\
\text { case heights. }\end{array}$ \\
\hline 92 & A & $\begin{array}{l}\text { Adjustments to plan } \\
\text { drawings and } \\
\text { agreement between } \\
\text { plans/perspectives }\end{array}$ & $\begin{array}{l}\text { Ensure luminaire agreement in strategy and } \\
\text { what is shown in drawing_agreement of ceiling } \\
\text { tiles/skylights/and luminaire types as well as } \\
\text { agreement with perspectives }\end{array}$ \\
\hline 41 & A & $\begin{array}{l}\text { Energy Savings } \\
\text { footer is non-obvious }\end{array}$ & $\begin{array}{l}\text { People are not understanding the purpose of the } \\
\text { energy savings footer. Some believe the } \\
\text { percentages refer to the work needed to } \\
\text { "complete" the application. We need an } \\
\text { explicit "Energy Savings" label for the } \\
\text { percentage bar. }\end{array}$ \\
\hline 80 & A & $\begin{array}{l}\text { Provide additional } \\
\text { daylighting and } \\
\text { controls } \\
\text { documentation in } \\
\text { downloaded report }\end{array}$ & \\
\hline 82 & A & $\begin{array}{l}\text { Navigation panel to } \\
\text { control strategies } \\
\text { unchecked } \\
\text { checkboxes }\end{array}$ & $\begin{array}{l}\text { From commenter: I proceeded through the } \\
\text { entire app using "Next" and selected all } 4 \\
\text { control strategies. When I clicked on Control } \\
\text { Strategies in the right pane_all of the } \\
\text { checkboxes were no longer marked. }\end{array}$ \\
\hline 93 & A & $\begin{array}{l}\text { Clarify intended } \\
\text { audience }\end{array}$ & $\begin{array}{l}\text { One thing missing is a description of "who is } \\
\text { this program intended for?" I wasn't sure if it } \\
\text { was for a client_architect_junior designer_or } \\
\text { senior designer. When I opened this program in } \\
\text { my browser_I had no knowledge of the intent } \\
\text { of the program nor any basic instructions of } \\
\text { how to use it. Perhaps a more descriptive } \\
\text { introductory page with a short description of the } \\
\text { intended user would help. }\end{array}$ \\
\hline
\end{tabular}




\begin{tabular}{|c|c|c|c|}
\hline TICKET \# & PRIORITY & SUMMARY & DESCRIPTION \\
\hline 94 & A & $\begin{array}{l}\text { Include glossary to } \\
\text { make technical } \\
\text { language accessible }\end{array}$ & $\begin{array}{l}\text { If you're trying to reach non-lighting experts_ } \\
\text { and this tool's point appears to be just that_- } \\
\text { there needs to be vignette description that is for } \\
\text { the non-lighting expert_then description for the } \\
\text { lighting expert to implement. There needs to be } \\
\text { in other words some layering of hte content to } \\
\text { appeal to the different audiences. As it is right } \\
\text { now_it is heavily oriented to lighting } \\
\text { experts_make language more accessible }\end{array}$ \\
\hline 103 & A & $\begin{array}{l}\text { Explanation for } \\
\text { requested information }\end{array}$ & $\begin{array}{l}\text { Tell folks the reason why we are asking for } \\
\text { hours. Controls strategies can vary. }\end{array}$ \\
\hline 100 & A & $\begin{array}{l}\text { Controls- provide } \\
\text { more implementation } \\
\text { guidance }\end{array}$ & $\begin{array}{l}\text { I think it would be interesting to provide } \\
\text { recommendations or more guidance about } \\
\text { controls_It will be important to provide detailed } \\
\text { guidance about how to execute the controls } \\
\text { strategies }\end{array}$ \\
\hline 108 & A & $\begin{array}{l}\text { Change } \\
\text { Luminaire/Lamp } \\
\text { Designations }\end{array}$ & $\begin{array}{l}\text { lamp catalog number (or code) should be } \\
\text { generic - here shown as a GE lamp } \\
\text { (SPX)T639W_ shouldn't there be a delimiter } \\
\text { between T6 and } 39 \text {. What about the difference } \\
\text { in lamps from } 35 \text { and } 39 \text { ? (note to CCJ: add } \\
\text { the caveat language that I sent to Barb for } \\
\text { ALG)_ }\end{array}$ \\
\hline 53 & A & $\begin{array}{l}\text { Energy code choice } \\
\text { not reflected in report }\end{array}$ & $\begin{array}{l}\text { From user: "The Energy Summary is showing } \\
\text { my baseline code incorrectly. I picked IECC } \\
2006 \text { and it shows } 90.1-2004 \text { in the Energy } \\
\text { Summary documentation." }\end{array}$ \\
\hline 69 & A & $\begin{array}{l}\text { Delete quotes at } \\
\text { beginning and end of } \\
\text { Assumptions and } \\
\text { delete "a" from } \\
\text { "design include a } \\
\text { dimensions" }\end{array}$ & \\
\hline 77 & A & $\begin{array}{l}\text { Some of the } \\
\text { photometric } \\
\text { icons/thumbnails are } \\
\text { still missing }\end{array}$ & $\begin{array}{l}\text { Make a list of what's missing and make sure it's } \\
\text { on the share drive. I think we got most of these } \\
\text { done but didn't get them fed into the database. }\end{array}$ \\
\hline
\end{tabular}




\begin{tabular}{|c|c|c|c|}
\hline TICKET \# & PRIORITY & SUMMARY & DESCRIPTION \\
\hline 48 & A & $\begin{array}{l}\text { Remove Vignette is } \\
\text { confusing }\end{array}$ & $\begin{array}{l}\text { Users are confused about how to remove a } \\
\text { Vignette from the Key Plan. They expect to be } \\
\text { able to uncheck the box and click "OK". The } \\
\text { explicit "Remove" link seems unwanted. } \\
\text { Perhaps we should only have the "OK" button_ } \\
\text { and have the current settings stored when the } \\
\text { user exits the dialog. }\end{array}$ \\
\hline 15 & A & Missing images & $\begin{array}{l}\text { We're missing the following hi-res RCP files: } \\
\text { VRG3c-RCP-IS.jpg VRG3c-RCP-DH.jpg } \\
\text { And the following hi-res perspective images: } \\
\text { VRG3c-RCP-DH.jpg VRG3c-PER-HI.jpg } \\
\text { VRG2c-PER-HI.jpg VRG2b-PER-HI.jpg } \\
\text { VRG2a-PER-HI.jpg VRG1c-PER-HI.jpg } \\
\text { VRG1b-PER-HI.jpg VRG1a-PER-HI.jpg }\end{array}$ \\
\hline 42 & A & $\begin{array}{l}\text { Can't see area input } \\
\text { after selecting a } \\
\text { Vignette }\end{array}$ & $\begin{array}{l}\text { The space area input is often hidden after the } \\
\text { user selects a vignette. Even if it is visible users } \\
\text { don't notice it at first. More attention should be } \\
\text { placed on the field so that users know what to } \\
\text { do next. }\end{array}$ \\
\hline 38 & A & $\begin{array}{l}\text { Feedback from a } \\
\text { Save operation is } \\
\text { non-obvious }\end{array}$ & $\begin{array}{l}\text { Several users mentioned issues with saving } \\
\text { projects_mostly related to not knowing when } \\
\text { their project is saved and when it is not. We } \\
\text { may want to differentiate the Save button from } \\
\text { the New and Load buttons. We also need } \\
\text { better feedback when a Save is complete. Users } \\
\text { mentioned the "Loading..." message from } \\
\text { DWR_ which is counterintuitive and address in } \\
\text { \#19. We should also have some sort of "Done" } \\
\text { message or icon that results from a callback } \\
\text { after the Save operation. }\end{array}$ \\
\hline 59 & A & $\begin{array}{l}\text { Grey out "Next" } \\
\text { button for required } \\
\text { fields }\end{array}$ & $\begin{array}{l}\text { I see a NEXT button appears when I fill out the } \\
\text { REQUIRED fields_but usually there is an } \\
\text { asterik next to required fields to alert me to that. } \\
\text { Suggest you GRAY OUT the NEXT button } \\
\text { rather than make invisible and add some } \\
\text { message about Required Fields next to it. This } \\
\text { is a web convention. }\end{array}$ \\
\hline 50 & A & $\begin{array}{l}\text { Users don't know } \\
\text { what to do with the } \\
\text { Key Plan }\end{array}$ & $\begin{array}{l}\text { The Key Plan interface is not intuitive. People } \\
\text { eventually figure it out_but it should be a little } \\
\text { more inviting to click on. }\end{array}$ \\
\hline
\end{tabular}




\begin{tabular}{|c|c|c|c|}
\hline TICKET \# & PRIORITY & SUMMARY & DESCRIPTION \\
\hline 29 & B & $\begin{array}{l}\text { Conditional logic for } \\
\text { images in } \\
\text { implementation } \\
\text { instructions }\end{array}$ & $\begin{array}{l}\text { The luminaire layout in the implementation } \\
\text { instructions requires conditional logic to list the } \\
\text { correct specific luminaire type on the page. }\end{array}$ \\
\hline 36 & B & $\begin{array}{l}\text { Backward navigation } \\
\text { is confusing }\end{array}$ & $\begin{array}{l}\text { Users are confused about how to step backward } \\
\text { in the process to adjust their information. } \\
\text { Admittedly_ I didn't think this was going to be } \\
\text { common use case; I assumed users would be } \\
\text { more interested in moving forward rather than } \\
\text { tweaking. The right-hand navigation is useful } \\
\text { to users once they understand that they can use } \\
\text { it_ but it's non-obvious. We should consider } \\
\text { re-working the "Next" functionality_possibly } \\
\text { adding a "Back" link and moving both into the } \\
\text { "Section Title" portion of the UI. }\end{array}$ \\
\hline 114 & B & $\begin{array}{l}\text { Changes in PDF } \\
\text { creation/labeling }\end{array}$ & $\begin{array}{l}\text { Change default name of "implementation"_- } \\
\text { Consider compressing files by lowering } \\
\text { resolution (commenter reduced } 10.2 \mathrm{MB} \text { to } 2.9 \\
\text { MB)_The spacing dimensions in the } \\
\text { implementation instructions are too small to } \\
\text { read. }\end{array}$ \\
\hline 102 & B & $\begin{array}{l}\text { Add links to } \\
\text { additional design } \\
\text { guidance/education }\end{array}$ & $\begin{array}{l}\text { Can we provide education about T8 vs. } \\
\text { T5?_Refer folks to the Light + Design Guide. } \\
\text { Far more specific and current than chapter } 10 \text { of } \\
\text { Handbook_Link to where requirements are } \\
\text { provided? IESNA table? }\end{array}$ \\
\hline 67 & B & $\begin{array}{l}\text { Remove extra } \\
\text { "Vignette Summary" } \\
\text { heading at end of } \\
\text { section }\end{array}$ & $\begin{array}{l}\text { There is a blurb at the end of each } \\
\text { implementation and summary that is not } \\
\text { supposed to be there_a repeat from above. }\end{array}$ \\
\hline 47 & B & $\begin{array}{l}\text { Check boxes are } \\
\text { confusing: users } \\
\text { expect checkbox } \\
\text { behavior }\end{array}$ & $\begin{array}{l}\text { The check boxes in the Vignette dialog behave } \\
\text { like HTML radio buttons_but users expect } \\
\text { HTML checkbox behavior. The Controls check } \\
\text { boxes exhibit that behavior_but they look the } \\
\text { same as the Vignette selection. We need to } \\
\text { differentiate these based on look_or make them } \\
\text { behave the same. }\end{array}$ \\
\hline
\end{tabular}




\begin{tabular}{|c|c|c|c|}
\hline TICKET \# & PRIORITY & SUMMARY & DESCRIPTION \\
\hline 73 & B & Create Help page & $\begin{array}{l}\text { The Help page should feature an index of the } \\
\text { content and text descriptions of each part of the } \\
\text { application with screenshots where applicable. } \\
\text { The Help page should also include a link to the } \\
\text { screencast. }\end{array}$ \\
\hline 44 & B & $\begin{array}{l}\text { Vignette selection } \\
\text { dialogs have size } \\
\text { issues }\end{array}$ & $\begin{array}{l}\text { The Highslide dialogs won't respect max-width } \\
\text { settings and sometimes when there are only one } \\
\text { or two vignettes to choose from you can't see } \\
\text { everything by default (you need to resize the } \\
\text { dialog manually). There's enough room to see } \\
\text { those_and they user shouldn't need to scroll in } \\
\text { those situations. This also exacerbates the } \\
\text { problem with the visibility of the space area } \\
\text { input. Consider switching to the jQuery UI } \\
\text { dialog_which is a little less fancy and may } \\
\text { require some work to set the size ourselves_but } \\
\text { we'll have better control over position and size } \\
\text { of the dialog. }\end{array}$ \\
\hline 105 & B & $\begin{array}{l}\text { Clarify what we } \\
\text { mean/process }\end{array}$ & $\begin{array}{l}\text { Grocery_ Do you really mean freezer cases or } \\
\text { refrigerated cases_. }\end{array}$ \\
\hline 4 & B & $\begin{array}{l}\text { Table of Contents for } \\
\text { PDF }\end{array}$ & \\
\hline 106 & B & $\begin{array}{l}\text { Provide Daylighting } \\
\text { Guidance }\end{array}$ & $\begin{array}{l}\text { Does the program tell me how many skylights } \\
\text { I need to achieve the savings that are promised? } \\
\text { You should provide meaningful guidance about } \\
\text { the non-electric light. Can you provide options } \\
\text { for different levels of daylighting? The choice } \\
\text { of how many skylights you use correlates with } \\
\text { savings_Design advice about toplighting is } \\
\text { needed for folks to be sold and to implement_ }\end{array}$ \\
\hline 61 & B & $\begin{array}{l}\text { Add selection option } \\
\text { for "all night } \\
\text { stocking" }\end{array}$ & $\begin{array}{l}\text { I have a store that stocks all night_can you add } \\
\text { a check box for all night stocking? }\end{array}$ \\
\hline 101 & B & $\begin{array}{l}\text { State applicability of } \\
\text { vignettes }\end{array}$ & $\begin{array}{l}\text { Are these vignettes for store open or for } \\
\text { stocking?_Obviously_severely limited in } \\
\text { choices right now in terms of design options. } \\
\text { Assume that these will continue to evolve. } \\
\text { Need to make it clear that these are not only } \\
\text { options; they are just useful ideas that have been } \\
\text { successfully implemented in }\end{array}$ \\
\hline
\end{tabular}




\begin{tabular}{|c|c|c|c|}
\hline TICKET \# & PRIORITY & SUMMARY & DESCRIPTION \\
\hline 99 & B & $\begin{array}{l}\text { Controls- clarify } \\
\text { control strategies of } \\
\text { designs }\end{array}$ & $\begin{array}{l}\text { You need to tell folks that the dimming only } \\
\text { applies to linear fluorescent_or they may not } \\
\text { choose daylight dimming because they know } \\
\text { CMH is in the design_ which shouldn't be } \\
\text { dimmed. It's good that you've made sure not to } \\
\text { dim the wrong layers_but you need to make } \\
\text { sure that people know this_The switching } \\
\text { during stocking_are we recommending } \\
\text { automatic or manual? Our implementation } \\
\text { guidance needs to require it to be } \\
\text { automatic_What areas are the controls applying } \\
\text { to? How do I know when daylighting is or is } \\
\text { not being used in a particular area? How do I } \\
\text { know that you are not dimming the metal } \\
\text { halide? }\end{array}$ \\
\hline 110 & B & $\begin{array}{l}\text { Double check energy } \\
\text { savings }\end{array}$ & $\begin{array}{l}\text { In a big box store_I would expect the } \\
\text { daylighting savings to be greater. When I hit } \\
\text { the controls strategy for daylighting it only } \\
\text { changed } 5 \% \text {. Double check the savings } \\
\text { calculations_(pharmacy) I believe this is the } \\
\text { only instance of parallel outperforming } \\
\text { perpendicular_Will the nighttime dimming only } \\
\text { be } 1-5 \% \text { If it's } 20 \% \text { or thereabouts_noone will } \\
\text { even notice that_I'm surprised the LPDs aren't } \\
\text { lower. Are you using light levels on the high } \\
\text { end? }\end{array}$ \\
\hline 86 & $\mathrm{C}$ & $\begin{array}{l}\text { Provide allowed LPD } \\
\text { for reference in } \\
\text { download packet }\end{array}$ & $\begin{array}{l}\text { Some people would like to see what they are } \\
\text { comparing to (allowed) in LPD's. Commenter: } \\
\text { "Would like to see tool reference back to either } \\
\text { energy code or IES for various information. } \\
\text { Any way to link to a specific chart with value } \\
\text { highlighted?" Make clear that LPD for vignettes } \\
\text { is for vignette, not allowable LPD }\end{array}$ \\
\hline 62 & $\mathrm{C}$ & $\begin{array}{l}\text { Support user-entered } \\
\text { space }\end{array}$ & $\begin{array}{l}\text { For the specialty" vignettes_can there be a } \\
\text { place where the user fills in the function so it is } \\
\text { easier to keep track of? Eg Coffee bar_or } \\
\text { flower shop. It should be possible to add more } \\
\text { than one specialty space_with the possibility of } \\
\text { different vignettes." We're thinking: give user } \\
\text { ability to enter additional spaces and/or } \\
\text { additional kwh (NOT vignettes) }\end{array}$ \\
\hline
\end{tabular}




\begin{tabular}{|c|c|c|c|}
\hline TICKET \# & PRIORITY & SUMMARY & DESCRIPTION \\
\hline 112 & $\mathrm{C}$ & $\begin{array}{l}\text { Possible changes to } \\
\text { current } \\
\text { Vignettes/luminaires }\end{array}$ & $\begin{array}{l}\text { Comments range from ballast type and } \\
\text { efficiency choices_lighting technology used in } \\
\text { certain spaces_controls recommendations_to } \\
\text { ballast location. Please see master spreadsheet } \\
\text { for specific comments }\end{array}$ \\
\hline 46 & $\mathrm{C}$ & $\begin{array}{l}\text { Automatically select } \\
\text { Energy Code based } \\
\text { on location }\end{array}$ & $\begin{array}{l}\text { Users have requested that the application } \\
\text { automatically select an Energy Code for them } \\
\text { based on location. Some have even suggested } \\
\text { that the field not be user-editable. }\end{array}$ \\
\hline 55 & $\mathrm{C}$ & $\begin{array}{l}\text { Loading the } \\
\text { "grocery" project for } \\
\text { ed1 @ world.com } \\
\text { introduces controls } \\
\text { weirdness }\end{array}$ & $\begin{array}{l}\text { Controls will be listed as "Undefined" and the } \\
\text { list seems to grow the more times you load the } \\
\text { project. }\end{array}$ \\
\hline 31 & $\mathrm{C}$ & $\begin{array}{l}\text { Import luminaire } \\
\text { from excel }\end{array}$ & $\begin{array}{l}\text { Develop a method to auto-pull excel formatted } \\
\text { luminaire schedule into database. }\end{array}$ \\
\hline 87 & $\mathrm{C}$ & $\begin{array}{l}\text { More detail is wanted } \\
\text { in Energy Summary }\end{array}$ & $\begin{array}{l}\text { Utilities in particular want to see energy savings } \\
\text { per vignette in the Energy Summary. e.g._kWh } \\
\text { per vignette_not just in summary. Can we } \\
\text { include load profiles_or some sense of demand } \\
\text { response opportunity? Commenter: "Would be } \\
\text { nice to see estimates of how much energy can } \\
\text { be saved with control strategies - currently only } \\
\text { have boxes checked." }\end{array}$ \\
\hline 74 & $\mathrm{C}$ & Redesign "intro" page & $\begin{array}{l}\text { The "intro" page with the New Project and Load } \\
\text { Project boxes could be used for something } \\
\text { more. We can include a 1-2-3-4 step graphic to } \\
\text { give the user a hint of what each project will } \\
\text { entail_and a link to the screencast which would } \\
\text { walk them through the application (similar to } \\
\text { how Apple does it with new products on their } \\
\text { homepage). }\end{array}$ \\
\hline
\end{tabular}




\begin{tabular}{|c|c|l|l|}
\hline TICKET \# & PRIORITY & SUMMARY & DESCRIPTION \\
\hline 57 & C & $\begin{array}{l}\text { Stuck between pages } \\
\text { - trouble navigating } \\
\text { back and forth }\end{array}$ & $\begin{array}{l}\text { I found that when navigating back and fourth by } \\
\text { clicking on the different titles in the } \\
\text { navigational bar on the right hand side of the } \\
\text { screen that the screen would get 'stuck' between } \\
\text { two input screens. For example: clicking back } \\
\text { and fourth between the bar titled 'Project } \\
\text { Description' and 'Design vignettes' results in the } \\
\text { screen displaying a 1/2 portion of each input } \\
\text { screen. Using the 'next' button while the screens } \\
\text { are stuck half-way results in a incomplete page } \\
\text { advancement such that the display remains } \\
\text { stuck between two input screens. For } \\
\text { troubleshooting purposes - my display } \\
\text { resolution is set to 1280 by 1024 pixels. }\end{array}$ \\
\hline
\end{tabular}




\begin{tabular}{|c|c|c|c|c|c|c|c|c|c|c|c|c|c|c|c|c|c|}
\hline & & & & & & & & & & IMPORTANCE & & & & & & RANK & IING \\
\hline Commenter ID \# & Ref\# & $\begin{array}{l}\text { Commenter } \\
\text { Category }\end{array}$ & 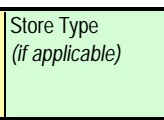 & 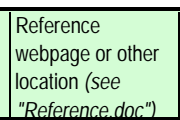 & Comment Description: Issues, Suggestions \& Requests & Action/Solution & Comment Type & $\begin{array}{c}\text { Status } \\
\text { or } \\
\text { Ticket\# }\end{array}$ & $\begin{array}{c}\text { Frequency } \\
(20 \%)\end{array}$ & $\begin{array}{c}\text { Importance of } \\
\text { comment } \\
(40 \%)\end{array}$ & $\begin{array}{l}\text { Sum } \\
(100 \%)\end{array}$ & $\begin{array}{l}\text { Ease of } \\
\text { Implementation } \\
(30 \%)\end{array}$ & $\begin{array}{l}\text { Duration } \\
(40 \%)\end{array}$ & $\begin{array}{c}\text { Riskl } \\
\text { Complication } \\
(30 \%)\end{array}$ & $\begin{array}{l}\text { Sum } \\
(100 \%)\end{array}$ & $\begin{array}{l}\text { Short Term } \\
\text { (40\% Important) } \\
\text { (600\% Feasible) }\end{array}$ & $\begin{array}{c}\text { Long Term } \\
(85 \% \text { Important) } \\
(15 \% \text { Feasible) }\end{array}$ \\
\hline D Oshinski & DO2 & Retailer & Big Box Discount & Vignette pop-ups & $\begin{array}{l}\text { Tabs for Approach, Strategy and Content are not easy enough to see. } \\
\text { They shouldnthe white }\end{array}$ & Flow & $\begin{array}{l}\text { Apperance/Aesth } \\
\text { etics }\end{array}$ & 89 & 2 & 5 & 4.4 & 5 & 5 & 5 & 5 & 39.5 & 32.4 \\
\hline D Oshinski & DO3 & Retaliler & Big Box Discount & Vignette pop-ups & 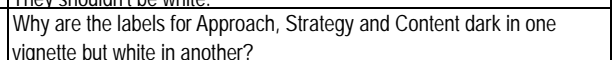 & Flow & $\begin{array}{l}\text { Apperance/Aesth } \\
\text { etics }\end{array}$ & 90 & 2 & 5 & 4.4 & 5 & 5 & 5 & 5 & 39.5 & 32.4 \\
\hline R Bartlett & RB6 & Generalist & & & $\begin{array}{l}\text { As soon as I I hanged the hours for Open/Close, the Pre-Open and Post- } \\
\text { Close drop down boxes became wider and hid part of the word "hours" } \\
\text { atter them. soit taboeared "hours" was misspelled }\end{array}$ & Style Changes & $\begin{array}{l}\text { Aivperance/asthet } \\
\text { ics }\end{array}$ & TBD & 1 & 4 & 3.4 & 5 & 3 & 1 & 3 & 31.6 & 33.4 \\
\hline $\begin{array}{c}\text { C Dilouie } \\
\end{array}$ & CD5 & Manufacturer & & New project & $\begin{array}{l}\text { This page screams for a graphic. Marketing opportunity here, maybe } \\
\text { continue the look from the first paae? }\end{array}$ & Style Changes & $\begin{array}{l}\text { Apperance/asthet } \\
\text { ics }\end{array}$ & 74 & 1 & 2 & 1.8 & 4 & 5 & 5 & 4.7 & 35.4 & 22.4 \\
\hline J Tuenge & JT8 & Core Team & Discount Big Box & \begin{tabular}{|l|} 
General - \\
Perpendicular 21
\end{tabular} & $\begin{array}{l}\text { The light gray background region is longer for this tab than for the other } \\
\text { tww. }\end{array}$ & Style Changes & $\begin{array}{l}\text { Asperancelasthet } \\
\text { ics }\end{array}$ & 115 & 1 & 3 & 2.6 & 5 & 5 & 5 & 5 & 40.4 & 29.6 \\
\hline B Hamilton & BH6 & Core Team & & & $\begin{array}{l}\text { The perspective and Overhead plans are barely big enough, but at least } \\
\text { I can sse what is going on and I know to scroll. Clearly you are vertically } \\
\text { challenged here. Is there a way to make the vignette pop-up a bit wider, } \\
\text { so you can see somewhat more of the text and perssective sketch } \\
\text { before needing to scroll? Since most vignettes only have } 2 \text { options. } \\
\text { wouldn't it make sense that they are both visibile instead of Barely not }\end{array}$ & Visibility Issues & $\begin{array}{l}\text { Apperance/asthet } \\
\text { ics }\end{array}$ & 37 & 3 & 4 & 3.8 & 4 & 5 & 5 & 4.7 & 43.4 & 39.4 \\
\hline S Stutzman & SS4 & Retalier & Specialty Market & Produce & $\begin{array}{l}\text { Could the thumbnails be a little larger so I can see them more clearly } \\
\text { from the vinentel list? }\end{array}$ & Visibility Issues & $\begin{array}{l}\text { Apperance/asthet } \\
\text { ics }\end{array}$ & 37 & 3 & 4 & 3.8 & 4 & 5 & 5 & 4.7 & 43.4 & 39.4 \\
\hline H Mckay & HM15 & Lighting Designer & & Perspective / plan & $\begin{array}{l}\text { The images are so tiny. I s it possible to click on them to enlarge them. } \\
\text { Can's see the track liahts or the letterina without a maanitving alass. }\end{array}$ & Visibility Issues & $\begin{array}{l}\text { Apperance/asthet } \\
\text { ics }\end{array}$ & 37 & 3 & 4 & 3.8 & 4 & 5 & 5 & 4.7 & 43.4 & 39.4 \\
\hline $\begin{array}{l}\text { C Dilouie } \\
\text {. }\end{array}$ & CD4 & Manufacturer & & all vignette pages & $\begin{array}{l}\text { First, perhaps the drawings could be clicked to see larger. After all, the } \\
\text { FM is going to be very concerned about how the lighting and } \\
\text { merchandise lavouts work toather. }\end{array}$ & Visibility Issues & $\begin{array}{l}\text { Apperancelasthet } \\
\text { ics }\end{array}$ & 37 & 3 & 4 & 3.8 & 4 & 5 & 5 & 4.7 & 43.4 & 39.4 \\
\hline R Bartlett & RB7 & Generalist & & & 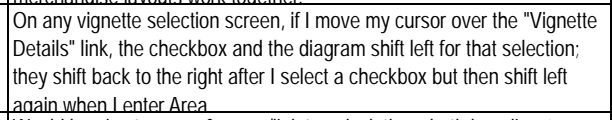 & Flow & $\begin{array}{l}\text { Apperancelasthet } \\
\text { ics }\end{array}$ & TBD & 1 & 5 & 4.2 & 5 & 5 & 5 & 5 & 46.8 & 43.2 \\
\hline J Pierce & JP17 & $?$ & & & Would be nice to see referencellink to calculation - both baseline \& new & Additions & Content & 86 & 2 & 3 & 2.8 & 1 & 1 & 1 & 1 & 17.2 & 25.3 \\
\hline JPierce & JP7 & $?$ & & & $\begin{array}{l}\text { Would like to see tool reference back to either energy code or IES for } \\
\text { various intormation. Any way to link to a speciific chart with value } \\
\text { highlighted? }\end{array}$ & Additions & Content & 86 & 2 & 3 & 2.8 & 2 & 3 & 3 & 2.7 & 27.4 & 27.9 \\
\hline Jierce & JP18 & ? & & Energy Summary & $\begin{array}{l}\text { Would be nice to see estimates of how much energy can be saved with } \\
\text { control strategies - currently only have boxes checked. }\end{array}$ & Additions & Content & 87 & 2 & 5 & 4.4 & 2 & 3 & 3 & 2.7 & 33.8 & 41.5 \\
\hline SMcDonald & SM17 & Generalist & & & $\begin{array}{l}\text { It might be neat to show how energy use varies depending on which } \\
\text { Enerav Code vou choose. Can't vou do above code? }\end{array}$ & Code Look-up & Content & TBD & 1 & 5 & 4.2 & 3 & 3 & 3 & 3 & 34.8 & 40.2 \\
\hline 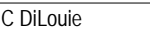 & CD18 & Manufacturer & & & Recommend having the report download link include a PDF icon so you & Additions & Content & 63 & 1 & 2 & 1.8 & 5 & 5 & 5 & 5 & 37.2 & 22.8 \\
\hline B Hamilton & BH26 & Core Team & Specialty Market & Implementation & 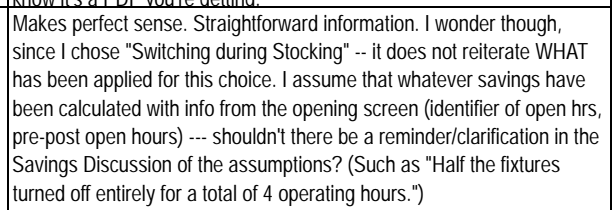 & Confusion & Content & 60 & 4 & 4 & 4 & 3 & 3 & 5 & 3.6 & 37.6 & 39.4 \\
\hline
\end{tabular}




\begin{tabular}{|c|c|c|c|c|c|c|c|c|c|c|c|c|c|c|c|c|c|}
\hline & & & & & & & & & & IMPORTANCE & & & & LITY & & RANK & KING \\
\hline Commenter ID \# & Ref\# & $\begin{array}{l}\text { Commenter } \\
\text { Category }\end{array}$ & 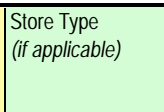 & \begin{tabular}{|l|} 
Reference \\
webpage or other \\
location $/$ sse? \\
Pe
\end{tabular} & Comment Description: Issues, Suggestions \& Requests & Action/Solution & Comment Type & $\begin{array}{c}\text { Status } \\
\text { or } \\
\text { Ticket \# }\end{array}$ & $\begin{array}{c}\text { Frequency } \\
(20 \%)\end{array}$ & $\begin{array}{l}\text { Importance of } \\
\text { comment } \\
(40 \%)\end{array}$ & $\begin{array}{l}\text { Sum } \\
(100 \%)\end{array}$ & $\begin{array}{l}\text { Ease of } \\
\text { Implementation } \\
(30 \%)\end{array}$ & $\begin{array}{l}\text { Duration } \\
(40 \%)\end{array}$ & $\begin{array}{c}\text { Risk/ } \\
\text { Complication } \\
(30 \%)\end{array}$ & $\begin{array}{c}\text { Sum } \\
(100 \%)\end{array}$ & $\begin{array}{l}\text { Short Term } \\
\text { (400\% Important) } \\
\text { (60\% Feasible) }\end{array}$ & $\begin{array}{l}\text { Long Term } \\
\text { (85\% Important) } \\
\text { (15\% Feasible) }\end{array}$ \\
\hline 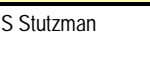 & sS10 & Retailer & & New project & \begin{tabular}{|l|} 
Can there be an option for overnight stocking? That is different from 24 \\
hours onen oneration.
\end{tabular} & Additions & Content & 61 & 2 & 4 & 3.6 & 4 & 4 & 4 & 4 & 38.4 & 36.6 \\
\hline G Arnold & GA9 & Utility & & Project Description & 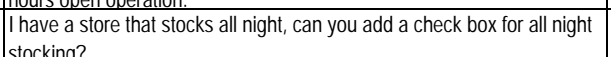 & Additions & Content & 61 & 3 & 4 & 3.8 & 4 & 4 & 4 & 4 & 39.2 & 38.3 \\
\hline N Miller & NM5 & Lighting Designer & Specialty Market & Barista & $\begin{array}{l}\text { Sotachase fill problem, } 3500 \mathrm{~K} \text { is its own bullet. } \\
\text { Date }\end{array}$ & Missing/Formatting & Content & 76 & 3 & 3 & 3 & 3.6 & 5 & 5 & 4.58 & 39.5 & 32.4 \\
\hline H Mckay & HM14 & Lighting Designer & & Project description & $\begin{array}{l}\text { At first picked gam instead of 9pm. Can o yu show a total open hours } \\
\text { summary (e. } 16 \text { hours) in casel missed the error? }\end{array}$ & Additions & Content & 60 & 1 & 3 & 2.6 & 5 & 5 & 5 & 5 & 40.4 & 29.6 \\
\hline J Tuenge & JT45 & Core Team & Grocery & \begin{tabular}{|l|} 
Bakery - Lensed w/ \\
nondation
\end{tabular} & The light gray background region is longer for the Approach tab than for & Missing/Formatting & Content & 115 & 1 & 3 & 2.6 & 5 & 5 & 5 & 5 & 40.4 & 29.6 \\
\hline J Tuenge & JT56 & Core Team & Specialty Market & \begin{tabular}{|l|} 
Spenanis \\
Specialty - both \\
ontios
\end{tabular} & 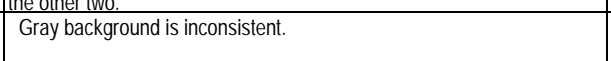 & Agreement & Content & 115 & 1 & 3 & 2.6 & 5 & 5 & 5 & 5 & 40.4 & 29.6 \\
\hline J Tuenge & JT4 & Core Team & Discount Big Box & $\begin{array}{l}\text { General - } \\
\text { Perpendicular } 21 \text { - }\end{array}$ & $\begin{array}{l}\text { The text "... displayed on 8-0 height gondolas" is broken into three bullet } \\
\text { points. }\end{array}$ & Missing/Formatting & Content & 76 & 3 & 3 & 3 & 4.4 & 5 & 5 & 4.82 & 40.9 & 32.7 \\
\hline J Tuenge & JT5 & Core Team & Discount Big Box & 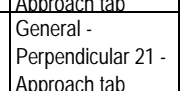 & 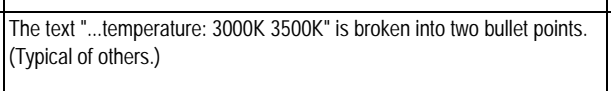 & Missing/Formatting & Content & 76 & 3 & 3 & 3 & 4.4 & 5 & 5 & 4.82 & 40.9 & 32.7 \\
\hline LDavis & LD32 & Lighting Designer & Specialty Market & $\begin{array}{l}\text { Vignette Details - } \\
\text { s: Both the }\end{array}$ & Lamp descriptions are different format from those in other retail outlets & Agreement & Content & 88 & 2 & 3 & 2.8 & 5 & 5 & 5 & 5 & 41.2 & 31.3 \\
\hline LDavis & LD22 & Lighting Designer & Grocery Store & \begin{tabular}{|l|} 
Specialty Store - \\
Fi pendant \& slot \\
light vignete
\end{tabular} & Not complete - no Concept or Criteria paragraphs & Missing/Formatting & Content & 78 & 2 & 5 & 3.4 & 4 & 5 & 5 & 4.7 & 41.8 & 36.0 \\
\hline LDavis & LD30 & Lighting Designer & Specialty Market & \begin{tabular}{|l|} 
Vignette Details- \\
General Sales \\
Luminaires parallel \\
to shelves
\end{tabular} & Luminaires - Descriptions are for the other vignette & Agreement & Content & 88 & 3 & 3 & 3 & 5 & 5 & 5 & 5 & 42.0 & 33.0 \\
\hline LDavis & LD31 & Lighting Designer & Specialty Market & $\begin{array}{l}\text { Vignette Details- } \\
\text { General Sales }\end{array}$ & Luminaires - Descriptions are for the other vignette & Agreement & Content & 88 & 3 & 3 & 3 & 5 & 5 & 5 & 5 & 42.0 & 33.0 \\
\hline LDavis & LD23 & Lighting Designer & Grocery Store & \begin{tabular}{|l|} 
Specialty Store- \\
Directlindirect \\
troffers, downlights, \\
and decorative \\
pendants
\end{tabular} & $\begin{array}{l}\text { Luminiair C does not match description of vignette (wet location } 2 \times 4 \text { not } \\
\text { directindirect troffer).; ; Criteria bullets need to be corrected(true in all } \\
\text { vignettes this area); }\end{array}$ & Missing/Formatting & Content & 88 & 3 & 4 & 3.8 & 4 & 5 & 5 & 4.7 & 43.4 & 39.4 \\
\hline LDavis & LD20 & Lighting Designer & Grocery Store & \begin{tabular}{|l|}
$\begin{array}{l}\text { Vignette Details-FL } \\
\text { pendants over } \\
\text { checkout }\end{array}$ \\
\end{tabular} & $\begin{array}{l}\text { lamp codes are not shown as in other store types in the Luminaires } \\
\text { section; }\end{array}$ & Missing/Formatting & Content & 75 & 1 & 4 & 3.4 & 5 & 5 & 5 & 5 & 43.6 & 36.4 \\
\hline B Hamilton & BH27 & Core Team & & & $\begin{array}{l}\text { Does the "Switching during Stocking" pdf I saw at choosing time print } \\
\text { too? Did I miss downlloading it? }\end{array}$ & Confusion & Content & 80 & 1 & 4 & 3.4 & 5 & 5 & 5 & 5 & 43.6 & 36.4 \\
\hline S Stutzman & SS6 & Retailer & Specialty Market & Control Strategies & $\begin{array}{l}\text { I picked the nightime dimming option on the controls strtategy page, but } \\
\text { the green bar didn't move. Arent' there any savings from that strategyy? }\end{array}$ & Functionality & Content & 79 & 2 & 5 & 4.4 & 4 & 5 & 4 & 4.4 & 44.0 & 44.0 \\
\hline sWilliams & SW12 & Retailer & & Project description & \begin{tabular}{|l} 
Dialogue box over pre and post open: Lighting controls strategies many \\
vary for stocking hours, vs. when customers are in the store.
\end{tabular} & Guidance & Content & 60 & 2 & 4 & 3.6 & 5 & 5 & 5 & 5 & 44.4 & 38.1 \\
\hline B Hamilton & BH15 & Core Team & Specialty Market & \begin{tabular}{|l} 
Produce, Track \\
Lighting \\
Highinhing \\
Produce (Linear \\
\end{tabular} & \begin{tabular}{|l|} 
Luminaire Type A does not match any luminaire that shows up in the \\
Final Luminair Schedule that comes in the Implementation instructions. \\
See Luminaire Schedule comments below.
\end{tabular} & Agreement & Content & 88 & 2 & 4 & 3.6 & 5 & 5 & 5 & 5 & 44.4 & 38.1 \\
\hline
\end{tabular}




\begin{tabular}{|c|c|c|c|c|c|c|c|c|c|c|c|c|c|c|c|c|c|}
\hline & & & & & & & & & & IMPORTANCE & & & & LITY & & RANK & ING \\
\hline Commenter ID\# & Ref\# & $\begin{array}{l}\text { Commenter } \\
\text { Category }\end{array}$ & 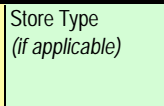 & \begin{tabular}{|l|} 
Reference \\
webpage or other \\
location ss: \\
le
\end{tabular} & Comment Description: Issues, Suggestions \& Requests & Action/Solution & Comment Type & $\begin{array}{c}\text { Status } \\
\text { or } \\
\text { Ticket \# }\end{array}$ & $\begin{array}{l}\text { Frequency } \\
(20 \%)\end{array}$ & $\begin{array}{l}\text { Importance of } \\
\text { comment } \\
(40 \%)\end{array}$ & $\begin{array}{l}\text { Sum } \\
(100 \%)\end{array}$ & $\begin{array}{c}\text { Ease of } \\
\text { Implementation } \\
(30 \%)\end{array}$ & 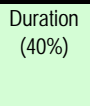 & $\begin{array}{c}\text { Risk/ } \\
\text { Complication } \\
(30 \%)\end{array}$ & $\begin{array}{l}\text { Sum } \\
(100 \%)\end{array}$ & $\begin{array}{c}\text { Short Term } \\
\text { (40\% Important) } \\
\text { (60\% Feasible) }\end{array}$ & $\begin{array}{c}\text { Long Term } \\
(85 \% \text { mportantt) } \\
(15 \% \text { Feasible) }\end{array}$ \\
\hline R Bartlett & RB12 & Generalist & Grocery Store & \begin{tabular}{|l|} 
Specialty Vignettes \\
- Fluorescent \\
pendants and slot \\
lighting over \\
merchandise
\end{tabular} & Has no content in Approach or Strategy & Missing/Formatting & Content & 78 & 2 & 5 & 4.6 & 4 & 5 & 5 & 4.4 & 44.8 & 45.7 \\
\hline J Tuenge & JT53 & Core Team & Pharmacy & $\begin{array}{l}\text { Center aisle - } \\
\text { between }\end{array}$ & \begin{tabular}{|l}
$\begin{array}{l}\text { Delete type B in schedule and Strategy, change B to Ain plan and } \\
\text { perspective. }\end{array}$ \\
\end{tabular} & Agreement & Content & 78 & 1 & 5 & 4.2 & 4 & 5 & 5 & 4.7 & 45.0 & 42.8 \\
\hline $\begin{array}{l}\text { M Mcateer } \\
\text { JThenae }\end{array}$ & $\begin{array}{ll}\text { MM6 } \\
1 T 29\end{array}$ & Utility & & & $\begin{array}{l}\text { The photometric curves are not showing up. } \\
\end{array}$ & \begin{tabular}{|l|l} 
Missing/Formatting \\
Micing/Formativg
\end{tabular} & Content & 77 & 3 & 4 & 3.8 & 5 & 5 & 5 & 5 & 45.2 & 39.8 \\
\hline J Tuenge & JT38 & Core Team & Grocery & $\begin{array}{l}\mid \begin{array}{l}\text { Produce - Adjust. } \\
\text { Accent }\end{array} \\
\text { - }\end{array}$ & No strategy given for types D and $\mathrm{E}$. & |Missing/Formatting & & 78 & 2 & 5 & 4.4 & 4 & 5 & 5 & 4.7 & 45.8 & 44.5 \\
\hline J Tuenge & Jт38 & Core Team & Grocery & $\begin{array}{l}\text { Produce - Adjust. } \\
\text { Accent }\end{array}$ & Type C strategy should be type $D$. & Missing/Formatting & Content & 78 & 2 & 5 & 4.4 & 4 & 5 & 5 & 4.7 & 45.8 & 44.5 \\
\hline J Tuenge & JT38 & Core Team & Grocery & \begin{tabular}{|l|} 
Produce - Adjust. \\
Accent
\end{tabular} & Type A strategy is incorrect. & Missing/Formatting & Content & 78 & 2 & 5 & 4.4 & 4 & 5 & 5 & 4.7 & 45.8 & 44.5 \\
\hline J Tuenge & JT40 & Core Team & Grocery & $\begin{array}{l}\text { Pharmacy - } \\
\text { Troffers }\end{array}$ & Type C i is incorrectly described as $2 \times 4$ in Strategy. & Missing/Formatting & Content & 78 & 2 & 5 & 4.4 & 4 & 5 & 5 & 4.7 & 45.8 & 44.5 \\
\hline JTuenge & JT43 & Core Team & Grocery & Bakery - Lensed & Approach and Strategy tabs missing text. & Missing/Formatting & Content & 78 & 2 & 5 & 4.4 & 4 & 5 & 5 & 4.7 & 45.8 & 44.5 \\
\hline J Tuenge & JT36 & Core Team & Grocery & \begin{tabular}{|l|} 
General/Long - \\
Permendicular
\end{tabular} & Missing text in Strategy tab. & Missing/Formatting & Content & 78 & 2 & 5 & 4.4 & 4 & 5 & 5 & 4.7 & 45.8 & 44.5 \\
\hline J Tuenge & JT41 & Core Team & Grocery & \begin{tabular}{|l|}
$\begin{array}{l}\text { Pharmacy- } \\
\text { Pendants }\end{array}$ \\
\end{tabular} & Type C is surface-mount in Strategy & Missing/Formatting & Content & 78 & 2 & 5 & 4.4 & 4 & 5 & 5 & 4.7 & 45.8 & 44.5 \\
\hline J Tuenge & JT29 & Core Team & Grocery & \begin{tabular}{|l|} 
Specialty - Fluor w/ \\
shltct
\end{tabular} & Missing text on Approach and Strategy tabs. & | Missing/Formatting & Content & 78 & 2 & 5 & 4.4 & 4 & 5 & 5 & 4.7 & 45.8 & 44.5 \\
\hline J Tuenge & JT32 & Core Team & Grocery & $\begin{array}{l}\text { Geveral//Short- } \\
\text { Perpendicular }\end{array}$ & No strategy given for dayighthing. & Missing/Formatting & Content & 80 & 2 & 5 & 4.4 & 4 & 5 & 5 & 4.7 & 45.8 & 44.5 \\
\hline J Tuenge & Jт34 & Core Team & Grocery & $\begin{array}{l}\begin{array}{l}\text { Generall/Short - } \\
\text { Cantilevered }\end{array} \\
\end{array}$ & Why are specialty areas addressed in daylighting strategy? & Missing/Formatting & Content & 105 & 2 & 5 & 4.4 & 4 & 5 & 5 & 4.7 & 45.8 & 44.5 \\
\hline J Tuenge & JT60 & Core Team & Specialty Market & \begin{tabular}{|l} 
General - \\
cantilevered
\end{tabular} & $\begin{array}{l}\text { Types A and B are erroneously described as pendant-mounted in } \\
\text { schedule. }\end{array}$ & Agreement & Content & 88 & 1 & 5 & 4.2 & 5 & 5 & 5 & 5 & 46.8 & 43.2 \\
\hline J Tuenge & JT56 & Core Team & Specialty Market & $\begin{array}{l}\text { Specialty - both } \\
\text { options }\end{array}$ & Photometric thumbnail image for type C should be Asymmetric. & Agreement & Content & 88 & 1 & 5 & 4.2 & 5 & 5 & 5 & 5 & 46.8 & 43.2 \\
\hline J Tuenge & JT59 & Core Team & Specialty Market & General - parallel & 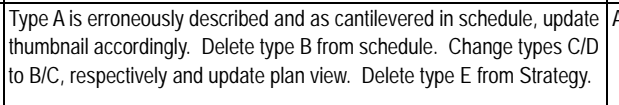 & Agreement & Content & 88 & 1 & 5 & 4.2 & 5 & 5 & 5 & 5 & 46.8 & 43.2 \\
\hline J Tuenge & JT58 & Core Team & Specialty Market & $\begin{array}{l}\text { Bakery- both } \\
\text { ootions }\end{array}$ & $\begin{array}{l}\text { Type Blamp should be CFL (not MH) in schedule, update thumbnail } \\
\text { accordinall. Tvoe E thumbnail should be Asvummetric. }\end{array}$ & Agreement & Content & 88 & 1 & 5 & 4.2 & 5 & 5 & 5 & 5 & 46.8 & 43.2 \\
\hline J Tuenge & JT34 & Core Team & Grocery & $\begin{array}{l}\text { General/Short - } \\
\text { Cantilevered }\end{array}$ & Concept describes aisles as wide rather than short. & Missing/Formatting & Content & 75 & 2 & 5 & 4.4 & 5 & 5 & 5 & 5 & 47.6 & 44.9 \\
\hline J Tuenge & JT44 & Core Team & Grocery & $\begin{array}{l}\begin{array}{l}\text { Bakery - Baskets } \\
\text { w/ pendants }\end{array} \\
\end{array}$ & If type $\mathrm{C}$ is a wet-rated direct-indirect, this requires more explanation. & Missing/Formatting & Content & 75 & 2 & 5 & 4.4 & 5 & 5 & 5 & 5 & 47.6 & 44.9 \\
\hline J Tuenge & JT45 & Core Team & Grocery & $\mid \begin{array}{l}\text { Bakery - Lensed w/ } \\
\text { nendant }\end{array}$ & If type $\mathrm{C}$ is a wet-rated direct-indirect, this requires more explanation. & Missing/Formatting & Content & 75 & 2 & 5 & 4.4 & 5 & 5 & 5 & 5 & 47.6 & 44.9 \\
\hline J Tuenge & JT32 & Core Team & Grocery & $\begin{array}{l}\text { General//Short - } \\
\text { Perpendicular }\end{array}$ & Photometric thumbnail images missing for types $\mathrm{A}$ and $\mathrm{B}$. & |Missing/Formatting & Content & 77 & 2 & 5 & 4.4 & 5 & 5 & 5 & 5 & 47.6 & 44.9 \\
\hline KAbernathy & KA8 & Lighting Designer & & \begin{tabular}{|l|} 
Specialty, \\
Fluorescent \\
pendants and slot \\
lightng over \\
merchandice
\end{tabular} & Under the approach tab, there is no content. & Missing/Formatting & Content & 78 & 2 & 5 & 4.4 & 5 & 5 & 5 & 5 & 47.6 & 44.9 \\
\hline KAbernathy & KA14 & Lighting Designer & & \begin{tabular}{|l|} 
Specialty, \\
Fluorescent \\
pendants and slot \\
lightng over \\
merchandise \\
\end{tabular} & Under the approach tab, there is no content. & Missing/Formatting & Content & 78 & 2 & 5 & 4.4 & 5 & 5 & 5 & 5 & 47.6 & 44.9 \\
\hline H Mckay & HM9 & Lighting Designer & Grocery & \begin{tabular}{|l|} 
luminaires \\
perpendicular
\end{tabular} & 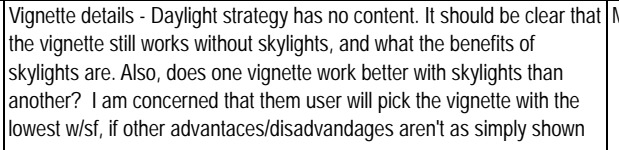 & Missing/Formatting & Content & 80 & 2 & 5 & 4.4 & 5 & 5 & 5 & 5 & 47.6 & 44.9 \\
\hline
\end{tabular}




\begin{tabular}{|c|c|c|c|c|c|c|c|c|c|c|c|c|c|c|c|c|c|}
\hline \multirow{2}{*}{$\overline{C o m m e n t e r ~ I D \# ~}$} & \multirow[b]{2}{*}{ Ref\# } & \multirow[b]{2}{*}{$\begin{array}{l}\text { Commenter } \\
\text { Category }\end{array}$} & \multirow[b]{2}{*}{ 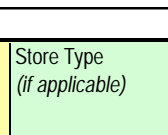 } & \multirow[b]{2}{*}{\begin{tabular}{|l|}
$\begin{array}{l}\text { Reference } \\
\text { webpage or other } \\
\text { location } / s e !\end{array}$ \\
\end{tabular}} & \multirow[b]{2}{*}{ Comment Description: Issues, Suggestions \& Requests } & \multirow[b]{2}{*}{ Action/Solution } & \multirow[b]{2}{*}{ Comment Type } & \multirow[b]{2}{*}{$\begin{array}{c}\text { Status } \\
\text { or } \\
\text { Ticket\# }\end{array}$} & \multicolumn{3}{|c|}{ IMPORTANCE } & \multicolumn{4}{|c|}{ FEASIBLITYY } & \multicolumn{2}{|c|}{ RANKING } \\
\hline & & & & & & & & & $\begin{array}{c}\text { Frequency } \\
(20 \%)\end{array}$ & $\begin{array}{l}\text { Importance of } \\
\text { comment } \\
(40 \%)\end{array}$ & $\begin{array}{c}\text { Sum } \\
(100 \%)\end{array}$ & $\begin{array}{c}\text { Ease of } \\
\text { Implementation } \\
(30 \%)\end{array}$ & $\begin{array}{l}\text { Duration } \\
(40 \%)\end{array}$ & $\begin{array}{l}\text { Risk/ } \\
\text { Complication } \\
(30 \%)\end{array}$ & $\begin{array}{c}\text { Sum } \\
(100 \%)\end{array}$ & $\begin{array}{l}\text { Short Term } \\
\left(\begin{array}{l}40 \% \text { II portantt } \\
\text { (60\%\% Feasible) }\end{array}\right.\end{array}$ & $\begin{array}{c}\text { Long Term } \\
\text { (85\% Important) } \\
\text { (15\% Feasible) }\end{array}$ \\
\hline J Tuenge & JT52 & Core Team & Pharmacy & Perimeter - $w /$ & Remove type B luminaire from schedule. & Agreement & Content & 88 & 2 & 5 & 4.4 & 5 & 5 & 5 & 5 & 47.6 & 44.9 \\
\hline J Tuenge & JT60 & Core Team & Specialty Market & General- & Show uplight in thumbnail for type $\mathrm{A}$. & Agreement & Content & 88 & 2 & 5 & 4.4 & 5 & 5 & 5 & 5 & 47.6 & 44.9 \\
\hline K Abernathy & KA7 & Lighting Designer & & $\begin{array}{l}\text { General Sales, } \\
\text { Short Aisles, } \\
\text { Luminaires } \\
\text { oriented } \\
\text { perpedicular to }\end{array}$ & The photometric curve icon is missing from the luminaire chart. & Missing/Formatting & Content & 77 & 3 & 5 & 4.6 & 5 & 5 & 5 & 5 & 48.4 & 46.6 \\
\hline J Tuenge & JT31 & Core Team & Grocery & $\begin{array}{l}\text { Spavect }- \text { Fluor w/ } \\
\text { dewnllahts }\end{array}$ & Photometric thumbnail image missing for type C. & Missing/Formatting & Content & 77 & 3 & 5 & 4.6 & 5 & 5 & 5 & 5 & 48.4 & 46.6 \\
\hline $\begin{array}{l}J \text { Tuenge } \\
\text { JThnge }\end{array}$ & JT39 & Core Team & 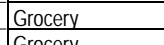 & 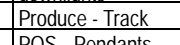 & $\begin{array}{l}\text { Photometric thumbnail image missing for type } \mathrm{B} \text {. } \\
\text { Dhotom }\end{array}$ & 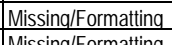 & $\begin{array}{llll}\text { Content } \\
\text { Contont }\end{array}$ & 77 & 3 & 5 & 4.6 & $\frac{5}{5}$ & $\frac{5}{5}$ & $\frac{5}{5}$ & $\frac{5}{5}$ & 48.4 & 46.6 \\
\hline $\begin{array}{l}\text { J luenne } \\
\text { J Tuenge }\end{array}$ & JT47 & Core Team & Grocery & $\begin{array}{l}\text { POS - Pendants w/ } \\
\text { T8 wall }\end{array}$ & 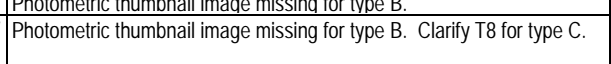 & 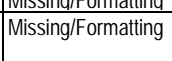 & Content & 77 & 3 & 5 & 4.6 & $\begin{array}{l}5 \\
5\end{array}$ & 5 & 5 & 5 & 48.4 & 46.6 \\
\hline $\begin{array}{lll}\text { L Davis } \\
\text { Junenge }\end{array}$ & LD28 & $\begin{array}{l}\text { Liqhtina Desianer } \\
\text { Sore Tam }\end{array}$ & Grocerv Store & $\begin{array}{l}\text { General Comment } \\
\end{array}$ & 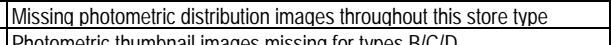 & Missing/Formatting & \begin{tabular}{|cccc} 
Content \\
Contont
\end{tabular} & 77 & 3 & 5 & 4.6 & 5 & $\frac{5}{5}$ & 5 & 5 & 48.4 & 46.6 \\
\hline J Juenge & J J34 & Core Team & Grocery & $\begin{array}{l}\text { Geenera/l/hhort- } \\
\text { Cantilevered }\end{array}$ & |Photometric thumbnail images missing for types B/CID. & Missing/Formatting & Content & 77 & 3 & 5 & 4.6 & 5 & 5 & 5 & 5 & 48.4 & 46.6 \\
\hline J Tuenge & JT38 & Core Team & Grocery & Produce - Adjust. & Photometric thumbnail images missing for types AB/CIE. & Missing/Formatting & Content & 77 & 3 & 5 & 4.6 & 5 & 5 & 5 & 5 & 48.4 & 46.6 \\
\hline J Tuenge & JT40 & Core Team & Grocery & Pharmacy- & Photometric thumbnail image missing for type B. & Missing/Formatting & Content & 77 & 3 & 5 & 4.6 & 5 & 5 & 5 & 5 & 48.4 & 46.6 \\
\hline J Tuenge & JT44 & Core Team & Grocery & $\begin{array}{l}\text { Bakery - Baskets } \\
\text { w/ nondantc }\end{array}$ & Photometric thumbnail image missing for type B. & Missing/Formatting & Content & 77 & 3 & 5 & 4.6 & 5 & 5 & 5 & 5 & 48.4 & 46.6 \\
\hline J Tuenge & JT45 & Core Team & Grocery & $\begin{array}{l}\text { Bakery - - Lensed W/ } \\
\text { pendants }\end{array}$ & Photometric thumbnail image missing for type B. & Missing/Formatting & Content & 77 & 3 & 5 & 4.6 & 5 & 5 & 5 & 5 & 48.4 & 46.6 \\
\hline J Tuenge & JT35 & Core Team & Grocery & Generall/Long - & Photometric thumbnail images missing for types $A$ and $B$. & Missing/Formatting & Content & 77 & 3 & 5 & 4.6 & 5 & 5 & 5 & 5 & 48.4 & 46.6 \\
\hline J Tuenge & JT37 & Core Team & Grocery & $\begin{array}{l}\text { Generall/Long- } \\
\text { Cantilevered }\end{array}$ & Photometric thumbnail images missing for types AB/CID. & Missing/Formatting & Content & 77 & 3 & 5 & 4.6 & 5 & 5 & 5 & 5 & 48.4 & 46.6 \\
\hline J Tuenge & JT41 & Core Team & Grocery & $\begin{array}{l}\text { Pharmacy- } \\
\text { Dendats }\end{array}$ & Photometric thumbnail image missing for types $B$ and $C$. & Missing/Formatting & Content & 77 & 3 & 5 & 4.6 & 5 & 5 & 5 & 5 & 48.4 & 46.6 \\
\hline J Tuenge & JT42 & Core Team & Grocery & $\begin{array}{l}\text { Pharmacy- } \\
\text { Stackights }\end{array}$ & Photometric thumbnail image missing for types $B$ and $C$. & Missing/Formatting & Content & 77 & 3 & 5 & 4.6 & 5 & 5 & 5 & 5 & 48.4 & 46.6 \\
\hline LDavis & LD8 & Lighting Designer & Discount Big Box & \begin{tabular}{|l|l|l|l} 
Vignette Details \\
\end{tabular} & \begin{tabular}{|l} 
polar plot of distribution is not for valence lighting, seems this needs to \\
rotate 90 dearres:
\end{tabular} & Missing/Formatting & Content & 77 & 3 & 5 & 4.6 & 5 & 5 & 5 & & 48.4 & 46.6 \\
\hline J Tuenge & JT29 & Core Team & Grocery & $\begin{array}{l}\text { Specially - Fluor wl } \\
\text { shlts }\end{array}$ & Photometric thumbnail images missing for types A and B. & Missing/Formatting & Content & 77 & 3 & 5 & 4.6 & 5 & 5 & 5 & 5 & 48.4 & 46.6 \\
\hline LDavis & LD20 & Lighting Designer & Grocery Store & $\begin{array}{l}\begin{array}{l}\text { Vignette Details-FL } \\
\text { pendants over } \\
\text { checkout }\end{array} \\
\end{array}$ & missing photometric distribution for type B & Missing/Formatting & Content & 77 & 3 & 5 & 4.6 & 5 & 5 & 5 & 5 & 48.4 & 46.6 \\
\hline B Hamilton & BH24 & Core Team & & & 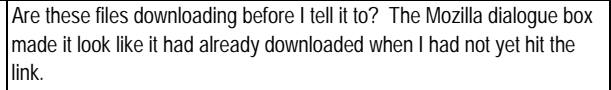 & Confusion & \begin{tabular}{|l} 
Download \\
Material
\end{tabular} & 63 & 1 & 5 & 4.2 & 5 & 5 & 5 & 5 & 46.8 & 43.2 \\
\hline B Hamilton & BH25 & Core Team & & & 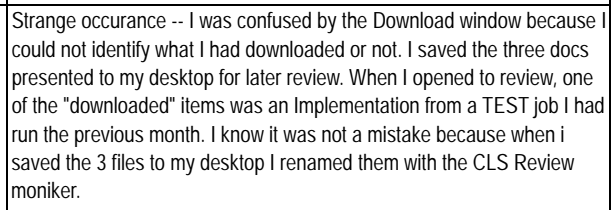 & Confusion & \begin{tabular}{|l} 
Download \\
Material
\end{tabular} & TBD & 1 & 5 & 4.2 & 5 & 5 & 5 & 5 & 46.8 & 43.2 \\
\hline S McDonald & SM14 & Generalist & & \begin{tabular}{|l|} 
Discount Big Box \\
Desian Vianettes \\
\end{tabular} & $\begin{array}{l}\text { It take it that the LPD is driven off my choice of "Energy Codes". I picked } \\
\text { ASHRAE } 2007 \text { so that vields LPD: } 0.91 \text { W/ft2 }\end{array}$ & Code Look-up & Ease of useffliow & 86 & 2 & 2 & 2 & 3 & 3 & 3 & 3 & 26.0 & 21.5 \\
\hline
\end{tabular}




\begin{tabular}{|c|c|c|c|c|c|c|c|c|c|c|c|c|c|c|c|c|c|}
\hline & & & & & & & & & & IMPORTANCE & & & & ILITY & & RANKI & IING \\
\hline Commenter ID\# & Ref\# & $\begin{array}{l}\text { Commenter } \\
\text { Category }\end{array}$ & 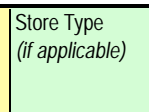 & 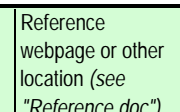 & Comment Description: Issues, Suggestions \& Requests & Accion/Solution & \begin{tabular}{|l|} 
Comment Type \\
\end{tabular} & $\begin{array}{l}\text { Status } \\
\text { or } \\
\text { Ticket\# }\end{array}$ & $\begin{array}{c}\text { Frequency } \\
(20 \%)\end{array}$ & $\begin{array}{c}\text { Importance of } \\
\text { comment } \\
(40 \%)\end{array}$ & $\begin{array}{c}\text { Sum } \\
(100 \%)\end{array}$ & $\begin{array}{c}\text { Ease of } \\
\text { Implementation } \\
(30 \%)\end{array}$ & $\begin{array}{c}\text { Duration } \\
(40 \%)\end{array}$ & $\begin{array}{c}\text { Risk/ } \\
\text { Complication } \\
(30 \%)\end{array}$ & $\begin{array}{c}\text { Sum } \\
(100 \%)\end{array}$ & $\begin{array}{c}\text { Short Term } \\
(40 \% \text { Important) } \\
\text { (600\% Feasible) }\end{array}$ & $\begin{array}{l}\text { Long Term } \\
\left(\begin{array}{ll}\text { (85\% Important) } \\
(15 \% \text { Feasible) }\end{array}\right.\end{array}$ \\
\hline G Arnold & GA11 & Utility & Grocery & $\begin{array}{l}\text { Grocery Store Key } \\
\text { Plan }\end{array}$ & 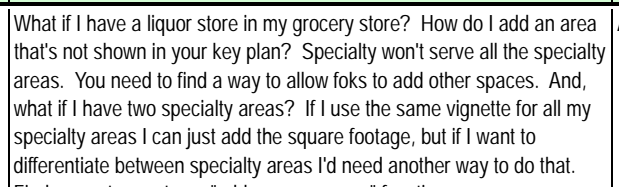 & Additions & Ease of use/flow & 62 & 3 & 4 & 3.8 & 2 & 2 & 2 & 2 & 27.2 & 35.3 \\
\hline CDilouie & CD17 & Manufacturer & & & 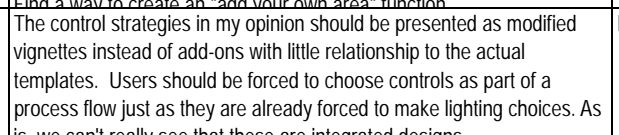 & Flow & Ease of usefflow & TBD & 2 & 4 & 3.6 & 3 & 2 & 3 & 2.6 & 30.0 & 34.5 \\
\hline S McDonald & SM5 & Generalist & & & 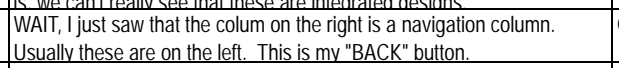 & \begin{tabular}{|l} 
Confusion \\
\end{tabular} & Ease of use/flow & 36 & 2 & 2 & 2 & 3 & 4 & 4 & 3.7 & 30.2 & 22.6 \\
\hline HMckay & $\begin{array}{ll}\text { HM19 } \\
\text { HM18 }\end{array}$ & \begin{tabular}{|l} 
Lighting Designer \\
Lighting Designer
\end{tabular} & & & $\begin{array}{l}\text { Or be able to rename the bakerv vignette to add a coffee bar. } \\
\text { For the "specialty" vignettes, can there be a place where the user fills in } \\
\text { the function so it is easier to keep track of? Eg Coffee bar, or fllower }\end{array}$ & \begin{tabular}{|l} 
Additions \\
Additions \\
\end{tabular} & \begin{tabular}{|l|} 
Ease of useflliow \\
Ease of use/flow
\end{tabular} & $\begin{array}{ll}62 \\
62\end{array}$ & $\frac{3}{5}$ & $\begin{array}{l}5 \\
5\end{array}$ & $\begin{array}{ll}4.6 \\
5\end{array}$ & $\frac{2}{2}$ & $\frac{2}{2}$ & $\frac{2}{2}$ & $\frac{2}{2}$ & $\begin{array}{l}30.4 \\
32.0\end{array}$ & 42.1 \\
\hline B Hamilton & BH18 & Core Team & & $\begin{array}{l}\text { Specialty Market } \\
\text { Key Plan }\end{array}$ & 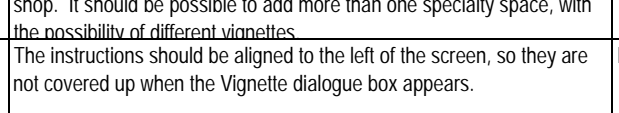 & Flow & Ease of use/flow & LT & 1 & 3 & 2.6 & 4 & 4 & 3 & 3.7 & 32.6 & 27.7 \\
\hline VBarr & VB3 & State & & & $\begin{array}{l}\text { There should be an option to remove a project from your list and one } \\
\text { project was listed three times after saving it once. }\end{array}$ & & Ease of use/flow & TBD & 3 & 4 & 3.8 & 3 & 3 & 3 & 3 & 33.2 & 36.8 \\
\hline & & & & & & Additions & & & & & & & & & & & \\
\hline \begin{tabular}{|l} 
L Coyan \\
\end{tabular} & LC4 & $?$ & & & $\begin{array}{l}\text { State selection should bring up what the state has adopted for an energy } \\
\text { code with the caviat that the local jurisdiction might be different. }\end{array}$ & Code Look-up & Ease of use/flow & 46 & & 5 & 4 & 3 & 3 & 3 & 3 & 34.0 & 38.5 \\
\hline C Dilouie & CD19 & Manufacturer & & & 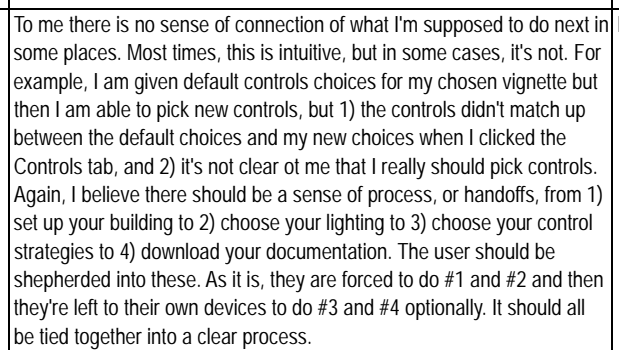 & Flow & Ease of use/flow & 74 & 1 & 3 & 2.6 & 5 & 4 & 3 & 4 & 34.4 & 28.1 \\
\hline S McDonald & SM13 & Generalist & & $\begin{array}{l}\text { Project Description } \\
\end{array}$ & $\begin{array}{l}\text { Iam assuming the building types are limited during the development } \\
\text { phase and will be expanded later. } \\
\text { Hmm. Why do we give a choice of Energy Codes. I know some states } \\
\text { ara slower at adoption, but would any user of THIS system want to use } \\
\text { anything LESS than the latest and greatest. ASHREE 90.1, for }\end{array}$ & Code Look-up & Ease of usefflow & 46 & 1 & 5 & 4.2 & 3 & 3 & 3 & 3 & 34.8 & 40.2 \\
\hline J Tuenge & JT1 & Core Team & & $\begin{array}{l}\text { Project Description } \\
\end{array}$ & 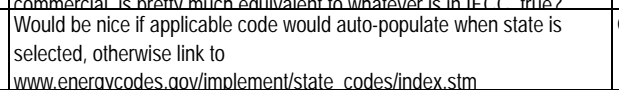 & Code Look-up & Ease of use/flow & 46 & 5 & 4 & 4.2 & 3 & 3 & 3 & 3 & 34.8 & 40.2 \\
\hline $\begin{array}{l}\text { N Miller } \\
\end{array}$ & NM30 & Liqhtina Desianer & & & $\begin{array}{l}\text { Code should autofill based on vour location. } \\
\text { Cors sil }\end{array}$ & Code Look-up & Ease of use/flow & 46 & 5 & 4 & 4.2 & 3 & 3 & 3 & 3 & 34.8 & 40.2 \\
\hline KAbernathy & KA2 & Lighting Designer & & & $\begin{array}{l}\text { It thould be very hillowituli the program already knew what the energy } \\
\text { code was based on the state. }\end{array}$ & Code Look-up & Ease of usefflow & 46 & 5 & 4 & 4.2 & 3 & 3 & 3 & 3 & 34.8 & 40.2 \\
\hline KAbernathy & KA11 & Lighting Designer & Grocery Store & $\begin{array}{l}\begin{array}{l}\text { Grocery Store Key } \\
\text { Plan }\end{array} \\
\end{array}$ & $\begin{array}{l}\text { It would be very helpiful if the program already knew what the energy } \\
\text { code was based on the state. }\end{array}$ & Code Look-up & Ease of uselfilow & 46 & 5 & 4 & 4.2 & 3 & 3 & 3 & 3 & 34.8 & 40.2 \\
\hline
\end{tabular}




\begin{tabular}{|c|c|c|c|c|c|c|c|c|c|c|c|c|c|c|c|c|c|}
\hline \multirow{2}{*}{ 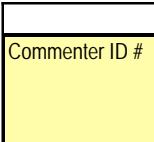 } & \multirow[b]{2}{*}{ Ref\# } & \multirow[b]{2}{*}{$\begin{array}{l}\text { Commenter } \\
\text { Category }\end{array}$} & \multirow[b]{2}{*}{$\begin{array}{l}\text { Store Type } \\
\text { |if applizabley }\end{array}$} & \multirow[b]{2}{*}{ 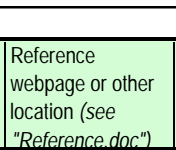 } & \multirow[b]{2}{*}{ Comment Description: Issues, Suggestions \& Requests } & \multirow[b]{2}{*}{ Action/Solution } & \multirow[b]{2}{*}{ Comment Type } & \multirow[b]{2}{*}{$\begin{array}{l}\text { Status } \\
\text { or } \\
\text { Ticket \# }\end{array}$} & \multicolumn{3}{|c|}{$\begin{array}{l}\text { IMPORTANCE } \\
\end{array}$} & \multicolumn{4}{|c|}{ FEASIBILITY } & \multicolumn{2}{|c|}{ RANKING } \\
\hline & & & & & & & & & $\begin{array}{l}\text { Frequency } \\
(20 \%)\end{array}$ & $\begin{array}{l}\text { Importance of } \\
\text { comment } \\
(40 \%)\end{array}$ & $\begin{array}{l}\text { Sum } \\
(100 \%)\end{array}$ & $\begin{array}{l}\text { Ease of } \\
\text { Implementation } \\
(30 \%)\end{array}$ & $\begin{array}{l}\text { Duration } \\
(40 \%)\end{array}$ & $\begin{array}{l}\text { Risk/ } \\
\text { Complication } \\
(30 \%)\end{array}$ & $\begin{array}{c}\text { Sum } \\
(100 \%)\end{array}$ & \begin{tabular}{|c|} 
Short Term \\
(40\% lmportant) \\
(60\%\% Feasible)
\end{tabular} & $\begin{array}{l}\text { Long Term } \\
(85 \% \text { mportant) } \\
\text { (15\% Feasible) }\end{array}$ \\
\hline S Stutzman & ss8 & Retailler & & Control Strategies & $\begin{array}{l}\text { When you get to the controls screen, can you pick more than one? } \\
\text { didn't read the into at first, perhaps it is s clear enought. }\end{array}$ & Confusion & Ease of usefflow & 47 & 1 & 3 & 2.6 & 4 & 4 & 5 & 4.3 & 36.2 & 28.6 \\
\hline J Pierce & JP8 & ? & & & $\begin{array}{l}\text { Need to make user fully aware (not apparent in first go-around) that the } \\
\text { LPD is based on the specific vignette design - not related to energy } \\
\text { allowed. Would be nic to have separate column indicating what is } \\
\text { allowewe vs what this design provides. }\end{array}$ & Guidance & Ease of usefflow & 86 & 3 & 5 & 4.6 & 3 & 3 & 3 & 3 & 36.4 & 43.6 \\
\hline G Subisak & GS1 & Manufacturer & & Sign-in & $\begin{array}{l}\text { I went to sign-in without having an account, make the new user feature } \\
\text { more obvious. }\end{array}$ & Guidance & Ease of usefflow & 71 & 4 & 2 & 2.4 & 4 & 5 & 5 & 4.7 & 37.8 & 27.5 \\
\hline s Williams & SW1 & Retailer & & Sign in & $\begin{array}{l}\text { Sign in processs should have two green boxes, to make it more obvious } \\
\text { that you need to set tup an account if you don't have one yet. "Sign-In" } \\
\text { or "Create }\end{array}$ & Guidance & Ease of usefflow & 71 & 4 & 2 & 2.4 & 4 & 5 & 5 & 4.7 & 37.8 & 27.5 \\
\hline KAbernathy & KA1 & Lighting Designer & & & $\begin{array}{l}\text { It wasn't obvious enough to me that I needed to create an account. Only } \\
\text { figured it out atter I couldn't sign in. Add a "new user" or "register." }\end{array}$ & Guidance & Ease of usefflow & 71 & 4 & 2 & 2.4 & 4 & 5 & 5 & 4.7 & 37.8 & 27.5 \\
\hline S McDonald & SM10 & Generalist & & \begin{tabular}{|l} 
Discount Big Box \\
Design Vignettes
\end{tabular} & 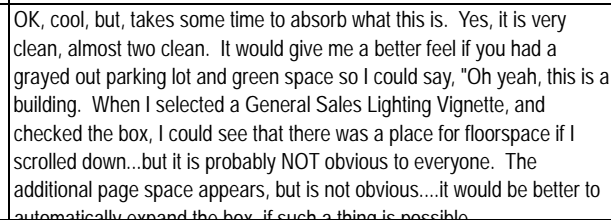 & Flow & Ease of use/flow & 44 & 5 & 5 & 5 & 2 & 3 & 4 & 3 & 38.0 & 47.0 \\
\hline LDavis & LD37 & Lighting Designer & Discount Big Box & General Sales & 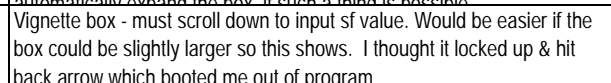 & Flow & Ease of usefflow & 44 & 5 & 5 & 5 & 2 & 3 & 4 & 3 & 38.0 & 47.0 \\
\hline T Betz & TB6 & ? & & & $\begin{array}{l}\text { Once a vignette is chosen, a scroll liara appears. The Area input box } \\
\text { appears below the visible portion of the window, forcing the user to scroll } \\
\text { down to tit. Is it possible to make the view window a little larger without a } \\
\text { scroll bar once avionette selection is made? }\end{array}$ & Guidance & Ease of usefflow & 44 & 5 & 5 & 5 & 2 & 3 & 4 & 3 & 38.0 & 47.0 \\
\hline B Hamilton & BH2O & Core Team & & Vignette pages & $\begin{array}{l}\text { Can the vignette box be slightly larger so there is no need to scroll? } \\
\text { Alternatelv. is there a wav for me to size the box? }\end{array}$ & Flow & Ease of usefflow & 44 & 5 & 5 & 5 & 2 & 3 & 4 & 3 & 38.0 & 47.0 \\
\hline S Stutzman & SS9 & Retailer & & Project Description & $\begin{array}{l}\text { How do I know which energy code is the right one? Can the webtool pull } \\
\text { the relevant energy code from azip code? }\end{array}$ & Code Look-up & Ease of usefllow & 46 & 5 & 5 & 5 & 3 & 3 & 3 & 3 & 38.0 & 47.0 \\
\hline S Williams & SW10 & Retailer & & Project description & $\begin{array}{l}\text { can you add state codes to the list? } \\
\end{array}$ & Code Look-up & Ease of use/fliow & 46 & 5 & 5 & 5 & 3 & 3 & 3 & 3 & 38.0 & 47.0 \\
\hline C Dilouie & CD1 & Manufacturer & & Project description & 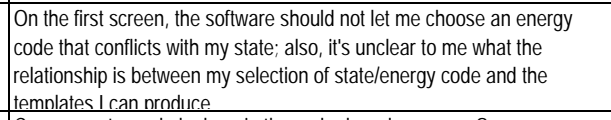 & Code Look-up & Ease of usefflow & 46 & 5 & 5 & 5 & 3 & 3 & 3 & 3 & 38.0 & 47.0 \\
\hline G Arnold & GA7 & Utility & & Project Description & Can you put a code look-up in the code drop down menu? & Code Look-up & Ease of usefflow & 46 & 5 & 5 & 5 & 3 & 3 & 3 & 3 & 38.0 & 47.0 \\
\hline $\begin{array}{l}\text { M Mcateer } \\
\end{array}$ & MM7 & Utility & & Project description & Please provide an autofill for code selection. & Code Look-up & Ease of usefflow & 46 & 5 & 5 & 5 & 3 & 3 & 3 & 3 & 38.0 & 47.0 \\
\hline HCKay & HM13 & Lighting Designer & & Project description & 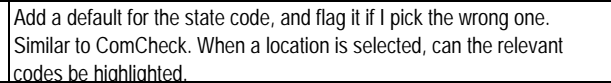 & Code Look-up & Ease of usefflow & 46 & 5 & 5 & 5 & 3 & 3 & 3 & 3 & 38.0 & 47.0 \\
\hline DDeVos & DD1 & Retailer & & & $\begin{array}{l}\text { Not sure which code is mine, can you tell me? An autofill would be very } \\
\text { helpul for national retailers because we do projects all over the country. }\end{array}$ & Code Look-up & Ease of usefflow & 46 & 5 & 5 & 5 & 3 & 3 & 3 & 3 & 38.0 & 47.0 \\
\hline$s$ Williams & SW11 & Retailer & & Project description & $\begin{array}{l}\text { Add a mouse-over dialogue box over the Energy Code. Should we pick } \\
\text { the baseline for the project? Clarify that it will be used to show baseline } \\
\text { energy consumption. This is important if someone wants to get a utility } \\
\text { incentive. }\end{array}$ & Additions & Ease of usefflow & 51 & 3 & 4 & 3.8 & 4 & 4 & 4 & 4 & 39.2 & 38.3 \\
\hline G Subisak & GS17 & Manufacturer & & Key Plans & $\begin{array}{l}\text { lavigating with the buttons on the right isn't intutitive, you'll need to tell } \\
\text { folks how to navigate. You are going forward with the next button and } \\
\text { backwards with the navication. }\end{array}$ & Guidance & Ease of use/flow & 36 & 3 & 5 & 4.6 & 3 & 4 & 4 & 3.7 & 40.6 & 44.7 \\
\hline
\end{tabular}




\begin{tabular}{|c|c|c|c|c|c|c|c|c|c|c|c|c|c|c|c|c|c|}
\hline & & & & & & & & & & IMPORTANCE & & & & LITY & & RANK & ING \\
\hline Commenter ID \# & Ref\# & $\begin{array}{l}\text { Commenter } \\
\text { Category }\end{array}$ & 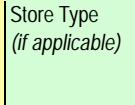 & $\begin{array}{l}\text { Reference } \\
\text { webpage or other } \\
\text { Iocation /se } \\
\text { lo }\end{array}$ & Comment Description: Issues, Suggestions \& Requests & Action/Solution & Comment Type & $\begin{array}{c}\text { Status } \\
\text { or } \\
\text { Ticket \# }\end{array}$ & $\begin{array}{l}\text { Frequency } \\
(20 \%)\end{array}$ & $\begin{array}{c}\text { Importance of } \\
\text { comment } \\
(40 \%)\end{array}$ & $\begin{array}{l}\text { Sum } \\
(100 \%)\end{array}$ & $\begin{array}{c}\text { Ease of } \\
\text { Implementation } \\
(30 \%)\end{array}$ & $\begin{array}{c}\text { Duration } \\
(40 \%)\end{array}$ & $\begin{array}{c}\text { Riskl } \\
\text { Complication } \\
(30 \%)\end{array}$ & $\begin{array}{l}\text { Sum } \\
(100 \%)\end{array}$ & $\begin{array}{c}\text { Short Term } \\
(40 \% \text { Important }) \\
\text { (60\% Feasible) }\end{array}$ & $\begin{array}{l}\text { Long Term } \\
(85 \% \text { Important) } \\
\text { (15\% Feasible) }\end{array}$ \\
\hline N Gordon & NG8 & ? & Grocery Store & Energy Summary & 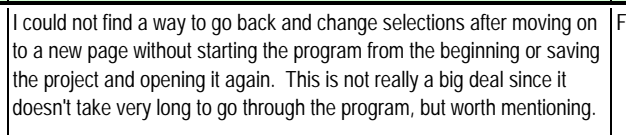 & Flow & Ease of use/flow & 36 & 3 & 5 & 4.6 & 3 & 4 & 4 & 3.7 & 40.6 & 44.7 \\
\hline T Betz & TB7 & $?$ & & Vignettes & 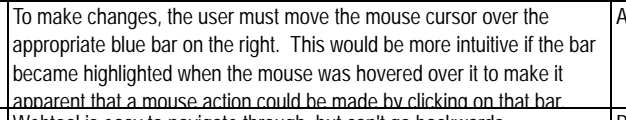 & Additions & Ease of use/filow & 36 & 3 & 5 & 4.6 & 3 & 4 & 4 & 3.7 & 40.6 & 44.7 \\
\hline J Pierce & JP13 & ? & & & 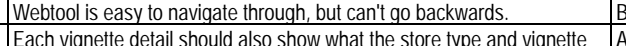 & 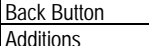 & $\begin{array}{c}\text { Ease of use/fliow } \\
\text { Ease of useflow }\end{array}$ & 36 & $\frac{3}{2}$ & $\frac{5}{3}$ & $\frac{4.6}{28}$ & $\frac{3}{5}$ & $\frac{4}{5}$ & $\frac{4}{5}$ & $\frac{3.7}{5}$ & 40.6 & 44.7 \\
\hline H Mckay & HM17 & Lighting Designer & & & $\begin{array}{l}\text { Each vignette detail should also show what the store type and vignette } \\
\text { tvoe are. It is hard to stav oriented. }\end{array}$ & Additions & Ease of use/flow & 64 & 2 & 3 & 2.8 & 5 & 5 & 5 & 5 & 41.2 & 31.3 \\
\hline HMckay & HM16 & Lighting Designer & & & $\begin{array}{l}\text { Each Vignette should also show you what the store type is. Should the } \\
\text { vignettes have a list number? To help folks know what theyve looked at } \\
\text { an reiected? }\end{array}$ & Additions & Ease of use/filow & 64 & 2 & 3 & 2.8 & 5 & 5 & 5 & 5 & 41.2 & 31.3 \\
\hline S McDonald & SM1 & Generalist & & Overall & $\begin{array}{l}\text { Would be nice to have "?" next to things like the drop down box for } \\
\text { Building Type so that users can learn what YOUR definitions for these } \\
\text { things are }\end{array}$ & Guidance & Ease of uselflow & 51 & 2 & 5 & 4.4 & 4 & 4 & 4 & 4 & 41.6 & 43.4 \\
\hline T Coughlin & TC6 & Utility & Pharmacy & $\begin{array}{l}\text { Perimeter } \\
\text { Vinentes }\end{array}$ & $\begin{array}{l}\text { I can't back out of the vignette. Even when I hit outside the box, it won't } \\
\text { close. Could be a cache issue. }\end{array}$ & Functionality & Ease of use/flow & 43 & 1 & 4 & 3.4 & 4 & 5 & 5 & 4.7 & 41.8 & 36.0 \\
\hline G Arnold & GAB & Utility & & Project Description & 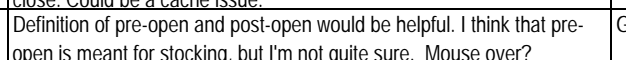 & Guidance & Ease of uselflow & 52 & 3 & 3 & 3 & 5 & 5 & 5 & 5 & 42.0 & 33.0 \\
\hline G Subisak & GS16 & Manufacturer & & Key Plans & $\begin{array}{l}\text { The metrics at the bottom of the screen, the energy savings bar should } \\
\text { have a bit of explanation. Some programs have a \% completed, I wasn't } \\
\text { sure if the \% w was how far youvive gotten through the webtol, or the } \\
\text { energy savings. Perhaps add the word "savings" atter the "x" \%. e.g., }\end{array}$ & Guidance & Ease of use/flow & 41 & 3 & 4 & 3.8 & 4 & 5 & 5 & 4.7 & 43.4 & 39.4 \\
\hline K Abernathy & KA19 & Lighting Designer & & Download & 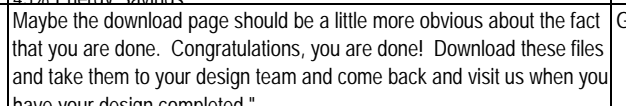 & Guidance & Ease of use/filow & 45 & 1 & 4 & 3.4 & 5 & 5 & 5 & 5 & 43.6 & 36.4 \\
\hline C Dilouie & CD7 & Manuffacturer & & Sign-in & $\begin{array}{l}\text { Add another dark green band toward bottom of box, with caps that say } \\
\text { REGISTER, while putting SIGN IN in black instead of white to stand out } \\
\text { more }\end{array}$ & Style changes & Ease of use/filow & 71 & 4 & 4 & 4 & 4 & 5 & 5 & 4.7 & 44.2 & 41.1 \\
\hline TBetz & TB5 & $?$ & & Vignettes & 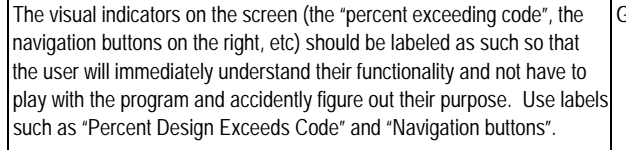 & Guidance & Ease of use/filow & 41 & 2 & 5 & 4.4 & 4 & 5 & 5 & 4.7 & 45.8 & 44.5 \\
\hline T Betz & TB3 & $?$ & & General & 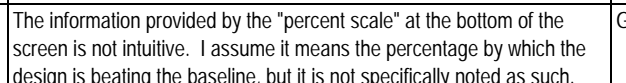 & Guidance & Ease of use/filow & 41 & 3 & 5 & 4.6 & 4 & 5 & 5 & 4.7 & 46.6 & 46.2 \\
\hline V Barr & VB7 & State & & Project description & 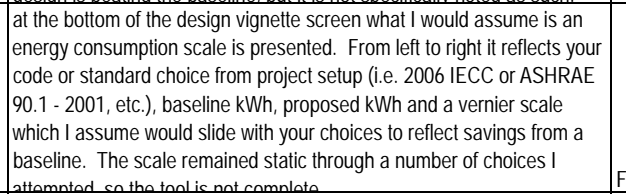 & Functionality & Ease of use/flow & 41 & 3 & 5 & 4.6 & 4 & 5 & 5 & 4.7 & 46.6 & 46.2 \\
\hline S McDonald & SM7 & Generalist & & & $\begin{array}{l}\text { goot to the last page "Downloads" and the progress bar sill reads } \\
600 \% \text {. although in looks like I am done. I am not sure what to do next, } \\
\text { ofher han download documents.s. }\end{array}$ & Guidance & Ease of use/fliow & 41 & 3 & 5 & 4.6 & 4 & 5 & 5 & 4.7 & 46.6 & 46.2 \\
\hline$\frac{\text { SWilliams }}{\text { KAbernathy }}$ & \begin{tabular}{|l|l} 
SW9 \\
KA15
\end{tabular} & \begin{tabular}{|l|} 
Retailer \\
Lighting Designer
\end{tabular} & & Vignettes & $\begin{array}{l}\text { How do you exit a vignette? } \\
\text { If 'm looking at a vignette and don't want to pick one, I can't get out of }\end{array}$ & Flow & $\begin{array}{l}\text { Ease of use/fllow } \\
\text { Ease of use/flow }\end{array}$ & 43 & $\begin{array}{l}3 \\
3\end{array}$ & $\frac{5}{5}$ & 4.6 & $\frac{4}{4}$ & $\begin{array}{l}5 \\
5\end{array}$ & $\frac{5}{5}$ & 4.7 & 46.6 & 46.2 \\
\hline T Betz & TB4 & (5) & & General & 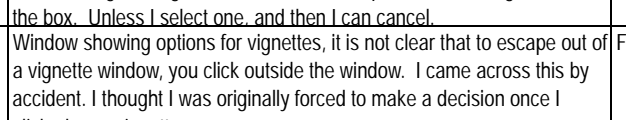 & Flow & Ease of use/filow & 43 & 3 & 5 & 4.6 & 4 & 5 & 5 & 4.7 & 46.6 & 46.2 \\
\hline
\end{tabular}




\begin{tabular}{|c|c|c|c|c|c|c|c|c|c|c|c|c|c|c|c|c|c|}
\hline \multirow{2}{*}{ Commenter ID\# } & \multirow[b]{2}{*}{ Ref\# } & \multirow[b]{2}{*}{$\begin{array}{l}\text { Commenter } \\
\text { Category }\end{array}$} & \multirow[b]{2}{*}{$\begin{array}{l}\text { Store Type } \\
\text { [it applica ble }\end{array}$} & \multirow[b]{2}{*}{\begin{tabular}{|l|}
$\begin{array}{l}\text { Reference } \\
\text { webpage or other } \\
\text { location /s? }\end{array}$ \\
\end{tabular}} & \multirow[b]{2}{*}{ Comment Description: Issues, Suggestions \& Requests } & \multirow[b]{2}{*}{ Action/Solution } & \multirow[b]{2}{*}{\begin{tabular}{|l|} 
Comment Type \\
\end{tabular}} & \multirow[b]{2}{*}{$\begin{array}{l}\text { Status } \\
\text { or } \\
\text { Ticket\# }\end{array}$} & \multicolumn{3}{|c|}{ IMPORTANCE } & \multicolumn{4}{|c|}{$\begin{array}{l}\text { FEASIBILITY } \\
\end{array}$} & \multicolumn{2}{|c|}{ RANKING } \\
\hline & & & & & & & & & $\begin{array}{l}\text { Frequency } \\
(20 \%)\end{array}$ & $\begin{array}{l}\text { Importance of } \\
\text { comment } \\
(40 \%)\end{array}$ & $\begin{array}{c}\text { Sum } \\
(100 \%)\end{array}$ & $\begin{array}{c}\text { Ease of } \\
\text { Implementation } \\
(30 \%)\end{array}$ & $\begin{array}{c}\text { Duration } \\
(40 \%)\end{array}$ & $\begin{array}{c}\text { Risk/ } \\
\text { Complication } \\
(30 \%)\end{array}$ & $\begin{array}{c}\text { Sum } \\
(100 \%)\end{array}$ & $\begin{array}{c}\text { Short Term } \\
\text { (40\% Important) } \\
\text { (60\% Feasible) }\end{array}$ & $\begin{array}{c}\text { Long Term } \\
(85 \% \text { mportantt) } \\
(15 \% \text { Feasible) }\end{array}$ \\
\hline B Hamilton & BH21 & Core Team & & Café Vignettes & 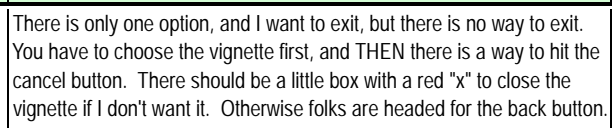 & Flow & Ease of uselflow | & 43 & 3 & 5 & 4.6 & 4 & 5 & 5 & 4.7 & 46.6 & 46.2 \\
\hline B Hamilton & BH22 & Core Team & & Caté Vignettes & $\begin{array}{l}\text { After you selecta vignette, you can toggle between them with your } \\
\text { CHEEKMARK but you should also be able to hit the check box and } \\
\text { have it de-select. }\end{array}$ & Flow & Ease of use/filow & 48 & 3 & 5 & 4.6 & 4 & 5 & 5 & 4.7 & 46.6 & 46.2 \\
\hline N Miller & NM15 & Lighting Designer & Specialty Market & $\begin{array}{l}\text { Track lighting } \\
\text { highlighting } \\
\text { oroduce }\end{array}$ & $\begin{array}{l}\text { When I check the box for one of the vignettes on the list, there is no way } \\
\text { to uncheck it except to pick the other vignette. The "remove from } \\
\text { proiect" ootion is missina. }\end{array}$ & Flow & Ease of use/filow & 48 & 3 & 5 & 4.6 & 4 & 5 & 5 & 4.7 & 46.6 & 46.2 \\
\hline DDeVos & DD12 & Retaliler & & & $\begin{array}{l}\text { The purpose of the bar at the bottom of the screen isn't readily apparent, } \\
\text { could be proaress throuah the tool. but tit's energy savinas. }\end{array}$ & Guidance & Ease of uselflow & 41 & 4 & 5 & 4.8 & 4 & 5 & 5 & 4.7 & 47.4 & 47.9 \\
\hline R Bartlett & RB14 & Generalist & & & 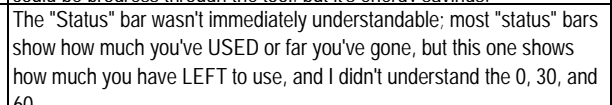 & Guidance & Ease of use/filow & 41 & 4 & 5 & 4.8 & 4 & 5 & 5 & 4.7 & 47.4 & 47.9 \\
\hline J Tuenge & JT51 & Core Team & & $\begin{array}{l}\text { Vignettes dialog } \\
\text { boxes }\end{array}$ & $\begin{array}{l}\text { The "Remove from project" link isn't intutitive -- users should simply } \\
\text { check whichever option they want or uncheck what they no longer want. } \\
\text { Similarly, the Cancel link only a appears after something is selected. }\end{array}$ & Flow & Ease of use/filow & 48 & 4 & 5 & 4.8 & 4 & 5 & 5 & 4.7 & 47.4 & 47.9 \\
\hline G Arnold & GA10 & Utility & & Vignettes & $\begin{array}{l}\text { It wasn't obvious to me that I should also hit the strategy and controls } \\
\text { tabs. There is very important information there, is there a way to make it } \\
\text { more obvious? Maybe buttons instead of tabs? Or numbering them? }\end{array}$ & Flow & Ease of use/flow & 89 & 2 & 5 & 4.4 & 5 & 5 & 5 & 5 & 47.6 & 44.9 \\
\hline M Hershman & & & & & $\begin{array}{l}\text { The flow seems somewhat logical, but it would be helpful during the } \\
\text { "desiogn vignette" page to instruct the user to please select an option and } \\
\text { enter the square footage of space. If you don't drag down, the square } \\
\text { fnotane dnes not show un }\end{array}$ & Flow & Ease of use/filow & 42 & 5 & 5 & 5 & 4 & 5 & 5 & 4.7 & 48.2 & 49.6 \\
\hline N Ferzacca & NF2 & Designs & Grocery & $\begin{array}{l}\text { General Sales } \\
\text { Aistes }\end{array}$ & Also, I cannot see the input box for the square footage. & Flow & Ease of use/flow & 42 & 5 & 5 & 5 & 4 & 5 & 5 & 4.7 & 48.2 & 49.6 \\
\hline N Miller & NM31 & Lighting Designer & & & 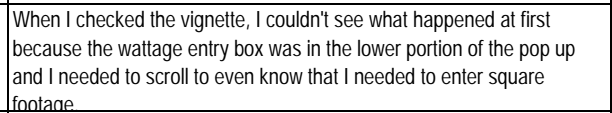 & Flow & Ease of use/filow & 42 & 5 & 5 & 5 & 4 & 5 & 5 & 4.7 & 48.2 & 49.6 \\
\hline CDilouie & CD16 & Manufacturer & & & $\begin{array}{l}\text { When the vignette pops up, the Area should have a stronger prompt, } \\
\text { like, "What is the area of this space?". It's not obvious enough to the } \\
\text { user what the next steo should be. }\end{array}$ & Guidance & Ease of use/flow & 42 & 5 & 5 & 5 & 4 & 5 & 5 & 4.7 & 48.2 & 49.6 \\
\hline S McDonald & SM4 & Generalist & & & 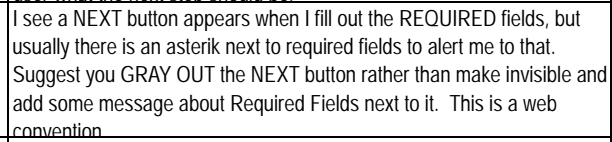 & Flow & Ease of use/flow & 59 & 3 & 5 & 4.6 & 5 & 5 & 5 & 5 & 48.4 & 46.6 \\
\hline R Bartlett & RB15 & Generalist & & Design Vignettes & 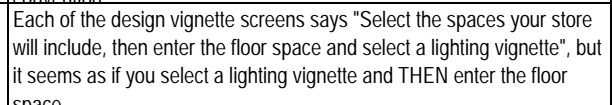 & Guidance & Ease of use/flow & 50 & 4 & 5 & 4.8 & 5 & 5 & 5 & 5 & 49.2 & 48.3 \\
\hline H Mckay & HM12 & Lighting Designer & & Key Plan & $\begin{array}{l}\text { At key plan, change to read "select the FIRST space that your store will } \\
\text { use." Rather than spaces. }\end{array}$ & Guidance & Ease of use/flow & 50 & 4 & 5 & 4.8 & 5 & 5 & 5 & 5 & 49.2 & 48.3 \\
\hline K Abernathy & KA12 & Lighting Designer & & \begin{tabular}{|l|} 
Grocery Store Key \\
Plan
\end{tabular} & $\begin{array}{l}\text { I was expecting that I needed to list my spaces, it went to the vignettes } \\
\text { and surprised me. I would have expected that I describe the spaces, } \\
\text { then the area, then designs. }\end{array}$ & Flow & Ease of use/fliow & 50 & 4 & 5 & 4.8 & 5 & 5 & 5 & 5 & 49.2 & 48.3 \\
\hline B Hamilton & BH17 & Core Team & Specialty Market & $\begin{array}{l}\text { Specialty Market } \\
\text { Key Plan }\end{array}$ & 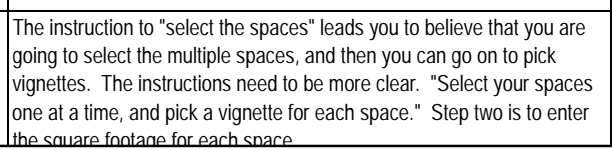 & Flow & Ease of usefflow & 50 & 4 & 5 & 4.8 & 5 & 5 & 5 & 5 & 49.2 & 48.3 \\
\hline
\end{tabular}




\begin{tabular}{|c|c|c|c|c|c|c|c|c|c|c|c|c|c|c|c|c|c|}
\hline & & & & & & & & & & IMPORTANCE & & & & ILITY & & RANK & IING \\
\hline Commenter ID\# & Ref\# & $\begin{array}{l}\text { Commenter } \\
\text { Category }\end{array}$ & 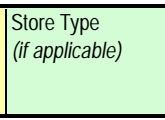 & 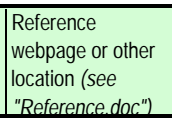 & Comment Description: Issues, Suggestions \& Requests & Action/Solution & Comment Type & $\begin{array}{c}\text { Status } \\
\text { or } \\
\text { Ticket \# }\end{array}$ & $\begin{array}{l}\text { Frequency } \\
(20 \%)\end{array}$ & $\begin{array}{c}\text { Importance of } \\
\text { comment } \\
(40 \%)\end{array}$ & $\begin{array}{l}\text { Sum } \\
(100 \%)\end{array}$ & $\begin{array}{c}\text { Ease of } \\
\text { Implementation } \\
(30 \%)\end{array}$ & $\begin{array}{c}\text { Duration } \\
(40 \%)\end{array}$ & $\begin{array}{c}\text { Riskl } \\
\text { Complication } \\
(30 \%)\end{array}$ & $\begin{array}{l}\text { Sum } \\
(100 \%)\end{array}$ & $\begin{array}{l}\text { Short Term } \\
(40 \% \text { Important) } \\
\text { (60\%\% Feasible) }\end{array}$ & $\begin{array}{c}\text { Long Term } \\
(85 \% \text { Important) } \\
(15 \% \text { Feasible) }\end{array}$ \\
\hline B Hamilton & BH19 & Core Team & & Vignette pages & $\begin{array}{l}\text { Could you add a roll-over/mouse-over on the vignette page that tells } \\
\text { people to pick a design and then it will OPEN the place to add sequare } \\
\text { footage? Being told to add square footage but not having the place to do } \\
\text { so visible vetis sanfusina }\end{array}$ & Flow & Ease of usefflow & 50 & 4 & 5 & 4.8 & 5 & 5 & 5 & 5 & 49.2 & 48.3 \\
\hline KAbernathy & KA13 & Lighting Designer & & $\begin{array}{l}\text { Grocery Store Key } \\
\text { Plan }\end{array}$ & $\begin{array}{l}\text { Oncee I see the space turn white, I Inow understand what this process is } \\
\text { about. Before that Ididn't know what to expect. }\end{array}$ & Confusion & Ease of use/flow & 50 & 4 & 5 & 4.8 & 5 & 5 & 5 & 5 & 49.2 & 48.3 \\
\hline S Stutzman & ssi1 & Retailer & Specialty Market & Key Plan & $\begin{array}{l}\text { Diriections must be more explicitit. E.g., " "Click on a store type to see a } \\
\text { vignete." Not immediately apparent about what to do when you get to } \\
\text { the kev plan. }\end{array}$ & Guidance & Ease of use/flow & 50 & 4 & 5 & 4.8 & 5 & 5 & 5 & 5 & 49.2 & 48.3 \\
\hline LDavis & LD26 & Lighting Designer & Grocery Store & Vignette Summary & $\begin{array}{l}\text { Nightime dimming shows up under Control Strategy but was not } \\
\text { selected: }\end{array}$ & Functionality & Functionallity & 55 & 1 & 2 & 1.8 & 4 & 4 & 2 & 3.4 & 27.6 & 20.4 \\
\hline T Coughhin & TC2 & Utility & & key plan & Button is blinking when I hit "next." & Functionality & Functionallity & TBD & 1 & 3 & 2.6 & 3 & 4 & 4 & 3.7 & 32.6 & 27.7 \\
\hline T Coughhin & TC3 & Utility & & vignette lists & Tabs are flashing when I run the mouse over the links. & Functionality & Functionallity & TBD & 1 & 3 & 2.6 & 3 & 4 & 4 & 3.7 & 32.6 & 27.7 \\
\hline T Coughhin & TC4 & Utility & & vignette lists & Going in and out of the vignettes-- sometimes the link isn't working. & Functionality & Functionallity & TBD & 2 & 3 & 2.8 & 3 & 4 & 4 & 3.7 & 33.4 & 29.4 \\
\hline M Hershman & MH1 & $?$ & & & 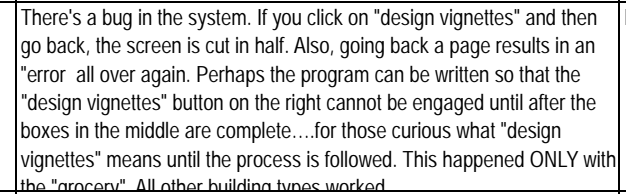 & Functionality & Functionallity & 57 & 3 & 5 & 4.6 & 3 & 3 & 2 & 2.7 & 34.6 & 43.2 \\
\hline B Manning & BM2 & ? & N/A & & 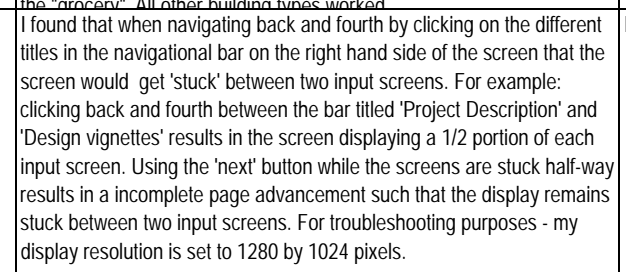 & Functionality & Functionallity & 57 & 3 & 5 & 4.6 & 3 & 3 & 2 & 2.7 & 34.6 & 43.2 \\
\hline LDavis & LD2 & Lighting Designer & Grocery Store & & Program Iocked up half way through and I had to start from scratch & Functionality & Functionallity & TBD & 2 & 5 & 4.4 & 3 & 3 & 3 & 3 & 35.6 & 41.9 \\
\hline J Tuenge & JT50 & Core Team & Grocery & $\begin{array}{l}\text { Downloads - } \\
\text { Luminaire Sched }\end{array}$ & \begin{tabular}{|l|} 
Link intermitently /inexplicably falls to work. May be caused by falilure \\
to select a control strategy.
\end{tabular} & Functionality & Functionallity & TBD & 2 & 5 & 4.4 & 3 & 3 & 3 & 3 & 35.6 & 41.9 \\
\hline J Tuenge & JT49 & Core Team & Grocery & Design Vignettes & \begin{tabular}{|l|} 
Found that atter selecting first option for each vignette and all four \\
control options, genereating PDF reports, and then going back to choose \\
another vignette, could not make changes that would persist thru \\
aeeneration of new PDF's.
\end{tabular} & Functionality & Functionallity & TBD & 2 & 5 & 4.4 & 3 & 3 & 3 & 3 & 35.6 & 41.9 \\
\hline K Abernathy & KA18 & Lighting Designer & & & 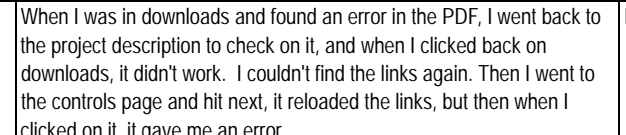 & Functionality & Functionallity & TBD & 3 & 5 & 4.6 & 3 & 3 & 3 & 3 & 36.4 & 43.6 \\
\hline R Bartlett & RB3 & Generalist & Pharmacy & \begin{tabular}{|l} 
Center Aisle \\
Vignette
\end{tabular} & $\begin{array}{l}\text { After I had hit "next" all the way through the app, I selected Design } \\
\text { Vignetese from the right pane. I had previously chosen the first vignette } \\
\text { and changed my choice to the second one. The area bar moved } \\
\text { appropriately and still had my entered area, but when I in OK, dialog } \\
\text { said "Please enter valid area for this space." I tried this on a different } \\
\text { vignette (General Sales), and it worked appropriately, but did not on this }\end{array}$ & Functionality & Functionallity & TBD & 1 & 5 & 4.2 & 3 & 3 & 4 & 3.3 & 36.6 & 40.7 \\
\hline T Coughlin & TC1 & Uutility & & project description & $\begin{array}{l}\text { Drop down menus, first time I selectede, it's picking the one below. When } \\
\text { you go back in and fix it, it's correct. Fix the fingering rule. }\end{array}$ & Functionality & Functionallity & 58 & 3 & 2 & 2.2 & 4 & 5 & 5 & 4.7 & 37.0 & 25.8 \\
\hline C Dilouie & CD3 & Manufacturer & & All & $\begin{array}{l}\text { llike that there will be a "Help" link that takes the visitor to a how-to } \\
\text { auide for the Tool, and sugacest that vou make it more prominent. }\end{array}$ & Style Changes & Functionallity & 73 & 1 & 2 & 1.8 & 5 & 5 & 5 & 5 & 37.2 & 22.8 \\
\hline
\end{tabular}




\begin{tabular}{|c|c|c|c|c|c|c|c|c|c|c|c|c|c|c|c|c|c|}
\hline & & & & & & & & & & IMPORTANCE & & & & ILITY & & RANKI & KING \\
\hline Commenter ID \# & Ref\# & $\begin{array}{l}\text { Commenter } \\
\text { Category }\end{array}$ & 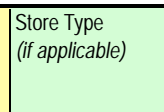 & 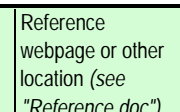 & Comment Description: Issues, Suggestions \& Requests & Accion/Solution & \begin{tabular}{|l|} 
Comment Type \\
\end{tabular} & $\begin{array}{c}\text { Status } \\
\text { or } \\
\text { Ticket \# }\end{array}$ & $\begin{array}{l}\text { Frequency } \\
(20 \%)\end{array}$ & $\begin{array}{c}\text { Importance of } \\
\text { comment } \\
(40 \%)\end{array}$ & $\begin{array}{c}\text { Sum } \\
(100 \%)\end{array}$ & $\begin{array}{c}\text { Ease of } \\
\text { Implementation } \\
(30 \%)\end{array}$ & $\begin{array}{c}\text { Duration } \\
(40 \%) \sigma_{0}\end{array}$ & $\begin{array}{c}\text { Risk/ } \\
\text { Complication } \\
(30 \%)\end{array}$ & $\begin{array}{c}\text { Sum } \\
(100 \%)\end{array}$ & $\begin{array}{c}\text { Short Term } \\
(40 \% \text { Important) } \\
\text { (600\% Feasible) }\end{array}$ & $\begin{array}{l}\text { Long Term } \\
\text { (85\% Important) } \\
\text { (15\% Feasible) }\end{array}$ \\
\hline R Bartlett & RB5 & Generalist & & Control Strtategies & 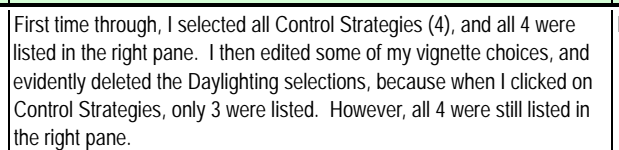 & Functionality & Functionallity & 55 & 2 & 5 & 4.4 & 4 & 4 & 2 & 3.4 & 38.0 & 42.5 \\
\hline T Betz & TB1 & $?$ & & & $\begin{array}{l}\text { Oops, hititing the back button in the web browser is a very bad idea. } \\
\text { How can you go back and make changes in the project? See below.... }\end{array}$ & Back Button & Functionallity & 35 & 5 & 4 & 4.2 & 3 & 4 & 4 & 3.7 & 39.0 & 41.3 \\
\hline V Barr & VB6 & State & & & 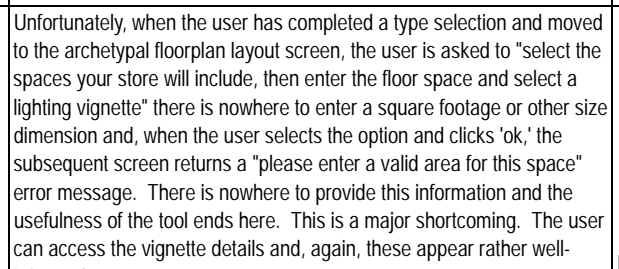 & Eunctionalite & Functionallity & 84 & & 3 & 2.4 & 5 & 5 & 5 & 5 & 39.6 & 27.9 \\
\hline L Davis & LD1 & Lighting Designer & Discount Big Box & General Sales & 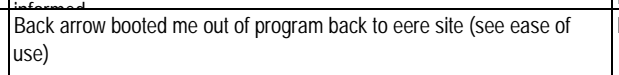 & Back Bulton & Functionallity & 35 & 5 & 5 & 5 & 3 & 4 & 4 & 3.7 & 42.2 & 48.1 \\
\hline S Stutzman & SS1 & Retailer & & Vignette pages & Back button three me out of the project, and I had to build a new project. & Back Button & Functionallity & 35 & 5 & 5 & 5 & 3 & 4 & 4 & 3.7 & 42.2 & 48.1 \\
\hline R Bartlett & RB1 & Generalist & & & $\begin{array}{l}\text { From vignettes page, hit Back and went all the way out of app; was only } \\
\text { by happenstance that Ifigured out later you could click outside the "box" } \\
\text { and do o b"back" }\end{array}$ & Flow & Functionallity & 35 & 5 & 5 & 5 & 3 & 4 & 4 & 3.7 & 42.2 & 48.1 \\
\hline 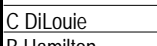 & $\mathrm{CD} 2$ & Manufacturer & & All & Should have back button functionality with my browser & Back Button & Functionallity & 35 & $\frac{5}{5}$ & $\frac{5}{5}$ & $\frac{5}{5}$ & $\frac{3}{3}$ & $\frac{4}{4}$ & $\frac{4}{4}$ & 3.7 & 42.2 & 48.1 \\
\hline 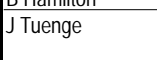 & JT2 & Core Team & & & 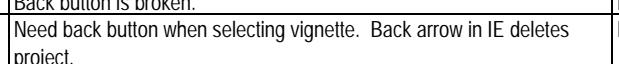 & 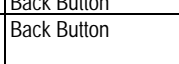 & 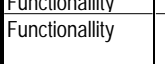 & 35 & $\frac{5}{5}$ & $\frac{5}{5}$ & $\frac{5}{5}$ & $\frac{3}{3}$ & $\frac{4}{4}$ & $\frac{4}{4}$ & 3.7 & 42.2 & 48.1 \\
\hline$J \operatorname{Linn}$ & JL15 & EEPS & & & Back button throws me out of the project, shows "error authorizing" and & Back Button & Functionallity & 35 & 5 & 5 & 5 & 3 & 4 & 4 & 3.7 & 42.2 & 48.1 \\
\hline S McDonald & SM3 & Generalist & & & 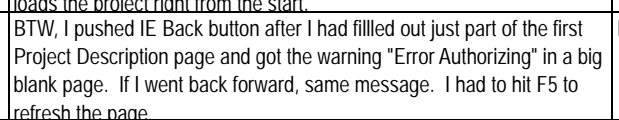 & Functionality & Functionallity & 35 & 5 & 5 & 5 & 3 & 4 & 4 & 3.7 & 42.2 & 48.1 \\
\hline Jierce & JP1 & $?$ & & & 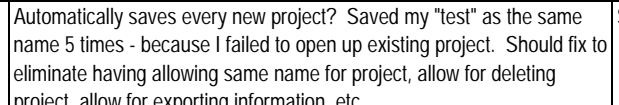 & Saving & Functionallity & 70 & 2 & 4 & 3.6 & 4 & 5 & 5 & 4.7 & 42.6 & 37.7 \\
\hline T Coughlin & TC5 & Utility & Pharmacy & Perimeter & Therer aignette isn'ts showing un up correctly. & Missing/Formatting & Functionallity & 49 & 1 & 4 & 3.4 & 5 & 5 & 5 & 5 & 43.6 & 36.4 \\
\hline C Dilouie & CD8 & Manufacturer & & Sign-in & $\begin{array}{l}\text { There is a strange glitch, there is a text fragment on the upper left side of } \\
\text { the screen, to the left of the logo, says "ting tool." Possibly becauseof } \\
\text { verv larae montior? }\end{array}$ & Functionality & Functionallity & 66 & 1 & 4 & 3.4 & 5 & 5 & 5 & 5 & 43.6 & 36.4 \\
\hline TCoughlin & TC5 & Utility & Pharmacy & $\begin{array}{l}\text { Perimeter } \\
\text { Viconots }\end{array}$ & The perspectives arent there & Missing/Formatting & Functionallity & 77 & 1 & 4 & 3.4 & 5 & 5 & 5 & 5 & 43.6 & 36.4 \\
\hline T Coughlin & TC5 & Utility & Pharmacy & $\begin{array}{l}\text { Vulantus } \\
\text { Perimeter }\end{array}$ & the checkbox is gone. & |Missing/Formatting & Functionallity & 115 & 1 & 4 & 3.4 & 5 & 5 & 5 & 5 & 43.6 & 36.4 \\
\hline J Tuenge & JT13 & Core Team & Discount Big Box & $\begin{array}{l}\text { POS - Over and } \\
\text { Wash 22 - Strategy } \\
\text { tab }\end{array}$ & \begin{tabular}{|l} 
Timed-out during review, and the log-in screen that popped-up didn't \\
work. (See Sheet3 review tab.) I was forced to start over.
\end{tabular} & Functionality & Functionallity & TBD & 3 & 5 & 4.6 & 4 & 5 & 4 & 4.4 & 44.8 & 45.7 \\
\hline Jierce & JP2 & ? & & & \begin{tabular}{|l|}
$\begin{array}{l}\text { Can't go backwards without starting over - -e.g. want to change to a } \\
\text { different viqnette }\end{array}$ \\
\end{tabular} & Flow & Functionallity & 48 & 2 & 5 & 4.4 & 5 & 4 & 5 & 4.6 & 45.2 & 44.3 \\
\hline S Williams & SW2 & Retailer & & Vignette page & $\begin{array}{l}\text { When I check a vignette, it does not give me a place to put in the square } \\
\text { footaca. }\end{array}$ & Functionality & Functionallity & 84 & 3 & 4 & 3.8 & 5 & 5 & 5 & 5 & 45.2 & 39.8 \\
\hline R Bartlett & RB4 & Generalist & & Control Strategies & 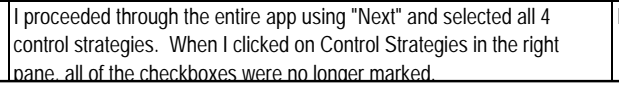 & Functionality & Functionallity & 82 & 2 & 5 & 4.4 & 5 & 5 & 4 & 4.7 & 45.8 & 44.5 \\
\hline
\end{tabular}




\begin{tabular}{|c|c|c|c|c|c|c|c|c|c|c|c|c|c|c|c|c|c|}
\hline & & & & & & & & & & IMPORTANCE & & & & & & RANK & \\
\hline Commenter ID \# & Ref\# & $\begin{array}{l}\text { Commenter } \\
\text { Category }\end{array}$ & 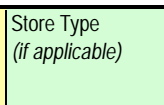 & 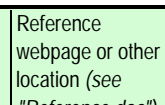 & Comment Description: Issues, Suggestions \& Requests & Action/Solution & Comment Type & $\begin{array}{c}\text { Status } \\
\text { or } \\
\text { Ticket\# }\end{array}$ & $\begin{array}{l}\text { Frequency } \\
(20 \%)\end{array}$ & $\begin{array}{l}\text { Impootance of } \\
\text { comment } \\
(40 \%)\end{array}$ & $\begin{array}{l}\text { Sum } \\
(100 \%)\end{array}$ & $\begin{array}{c}\text { Ease of } \\
\text { Implementation } \\
(30 \%)\end{array}$ & $\begin{array}{c}\text { Duration } \\
(40 \%)\end{array}$ & $\begin{array}{c}\text { Riskl } \\
\text { Complication } \\
(30 \%)\end{array}$ & $\begin{array}{c}\text { Sum } \\
(100 \%)\end{array}$ & $\begin{array}{c}\text { Short Term } \\
(400 \% \text { Important }) \\
(60 \% \text { Feasible) }\end{array}$ & $\begin{array}{c}\text { Long Term } \\
\text { (85\% Important) } \\
\text { (15\% Feasible) }\end{array}$ \\
\hline VBarr & VB4 & State & & & $\begin{array}{l}\text { In selecting a project location from the drop-down boxes present, the } \\
\text { selection consitsently missses my y hoice. Selecting New York repeatedly } \\
\text { gave me North Carolina and the other drop-down box selections made } \\
\text { similar mis-direction errors. }\end{array}$ & Functionality & Functionallity & 58 & 3 & 5 & 4.6 & 4 & 5 & 5 & 4.7 & 46.6 & 46.2 \\
\hline SWilliams & SW3 & Retailer & Grocery & short aisles & $\begin{array}{l}\text { When I tried to look at the thumbnail for short aisles in grocery, it didn't } \\
\text { on in }\end{array}$ & Missing/Formatting & Functionallity & 15 & 1 & 5 & 4.2 & 5 & 5 & 5 & 5 & 46.8 & 43.2 \\
\hline Devos & DD2 & Retailer & Big box discount & $\begin{array}{l}\text { Luminaires } \\
\text { perpendicular to } \\
\text { selves }\end{array}$ & $\begin{array}{l}\text { Woo ube } \text { I opened the Luminaires perrendicular to shelves vignettes, there } \\
\text { was no perspective thumbnail vignette. }\end{array}$ & Missing/Formatting & Functionallity & 15 & 2 & 5 & 4.4 & 5 & 5 & 5 & 5 & 47.6 & 44.9 \\
\hline $\begin{array}{l}\text { N Ferzacca } \\
\end{array}$ & NF1 & Designs & Grocery & General Sales & $\begin{array}{l}\text { When I hit the general sales aisles vignette, the pop up did not show the } \\
\text { thtumbrile }\end{array}$ & Missing/Formating & Functionallity & 15 & 2 & 5 & 4.4 & 5 & 5 & 5 & 5 & 47.6 & 44.9 \\
\hline G Subisak & GS2 & Manufacturer & & Vignette List & 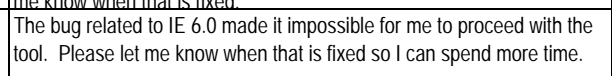 & Functionality & Functionallity & 84 & 2 & 5 & 4.4 & 5 & 5 & 5 & 5 & 47.6 & 44.9 \\
\hline B Hamilton & BH1 & Core Team & & & $\begin{array}{l}\text { Interentet Explorer has given me BIG problems with this webtool. We } \\
\text { could never actually make IE work (interface properly), but it was }\end{array}$ & Functionality & Functionallitity & 84 & 2 & 5 & 4.4 & 5 & 5 & 5 & 5 & 47.6 & 44.9 \\
\hline
\end{tabular}




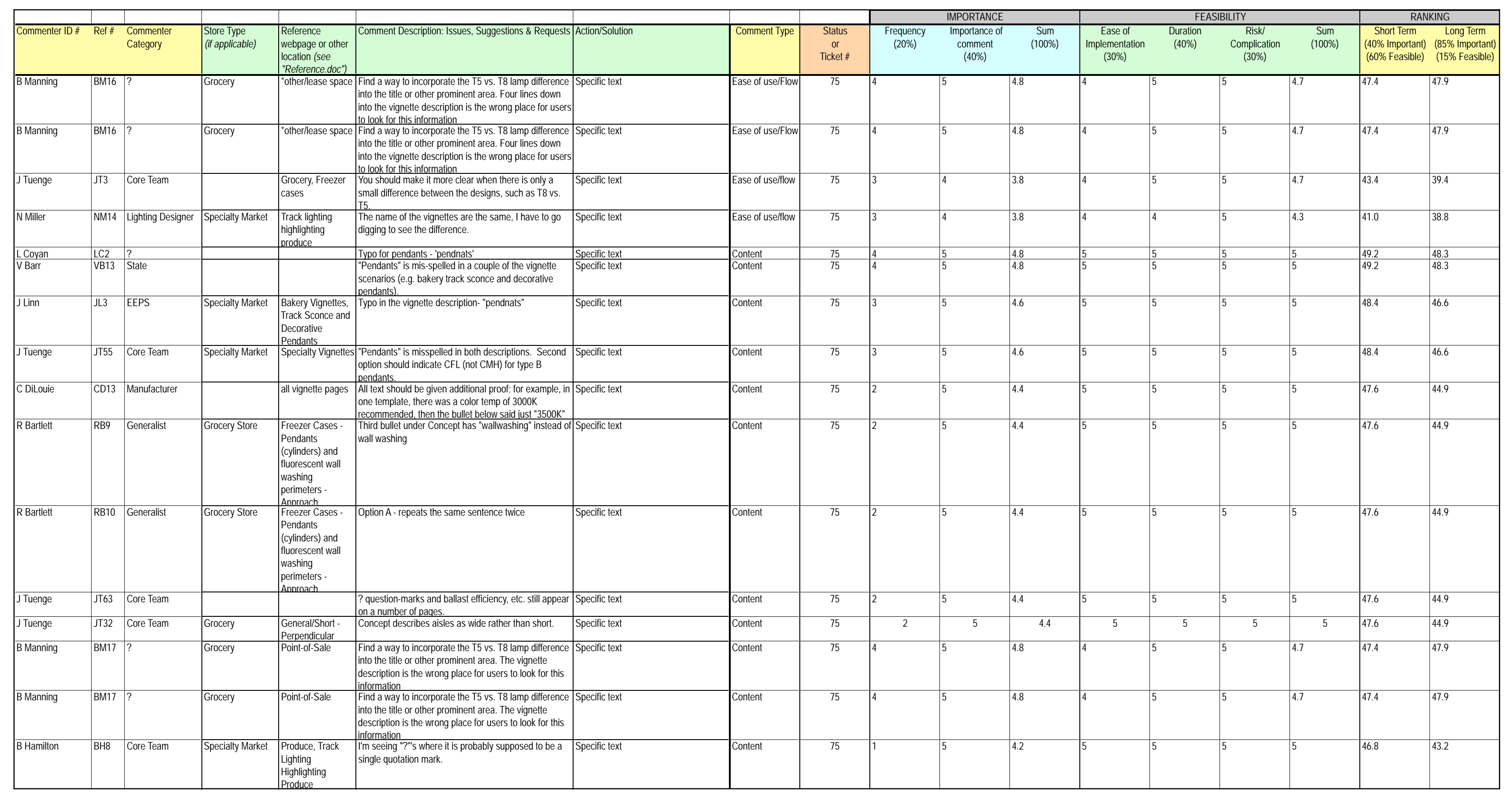




\begin{tabular}{|c|c|c|c|c|c|c|c|c|c|c|c|c|c|c|c|c|c|}
\hline & & & & & & & & & & IMPORTANCE & & & $\mathrm{FE}$ & SIBILITY & & RAN & VINING \\
\hline Commenter ID \# & Ref\# & $\begin{array}{l}\text { Commenter } \\
\text { Category }\end{array}$ & $\begin{array}{l}\text { Store Type } \\
\text { (iitiplicalle) }\end{array}$ & 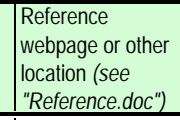 & Comment Description: Issues, Suggestions \& Requests & Action/Solution & \begin{tabular}{|c|} 
Comment Type \\
\end{tabular} & $\begin{array}{c}\text { Status } \\
\text { or } \\
\text { Ticket\# }\end{array}$ & $\begin{array}{c}\text { Frequency } \\
(20 \%)\end{array}$ & $\begin{array}{l}\text { Importance of } \\
\text { comment } \\
(40 \%)\end{array}$ & $\begin{array}{c}\text { Sum } \\
(100 \%)\end{array}$ & \begin{tabular}{|c|} 
Ease of \\
Implementation \\
$(30 \%)$
\end{tabular} & $\begin{array}{c}\text { Duration } \\
(40 \%)\end{array}$ & $\begin{array}{c}\text { Risk/ } \\
\text { Complication } \\
(30 \%)\end{array}$ & $\begin{array}{c}\text { Sum } \\
(100 \%)\end{array}$ & $\begin{array}{l}\text { Short Term } \\
\text { (40\% Important) } \\
\text { (60\% Feasible) }\end{array}$ & $\begin{array}{l}\text { Long Term } \\
\text { (85\% Important) } \\
\text { (15\% Feasible) }\end{array}$ \\
\hline B Hamilton & BH9 & Core Team & Specialty Market & \begin{tabular}{|l|} 
Produce, Track \\
Lighting \\
Highlighting \\
Produce (Linear \\
Fluorescent) \\
\end{tabular} & 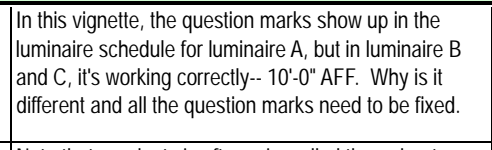 & Specific text & Content & 75 & 1 & 5 & 4.2 & 5 & 5 & 5 & 5 & 46.8 & 43.2 \\
\hline B Hamilton & BH10 & Core Team & & Caté Vignettes & \begin{tabular}{|l} 
Notet that pendnats is often misspelled throughout \\
(been copied/pasted).
\end{tabular} & Specific text & Content & 75 & 1 & 5 & 4.2 & 5 & 5 & 5 & 5 & 46.8 & 43.2 \\
\hline B Hamilton & BH12 & Core Team & Specialty Market & $\begin{array}{l}\text { Produce, Track } \\
\text { Lighting } \\
\text { Highighting } \\
\text { Produce (Linear } \\
\text { Flurescent) }\end{array}$ & ?'s are also showing up in the Strategy tabs. & Specific text & Content & 75 & 1 & 5 & 4.2 & 5 & 5 & 5 & 5 & 46.8 & 43.2 \\
\hline B Hamilton & BH14 & Core Team & Specialty Market & $\begin{array}{l}\text { Produce, Track } \\
\text { Lighting } \\
\text { Highighting } \\
\text { Produce (Linear } \\
\text { Fluerescent) }\end{array}$ & 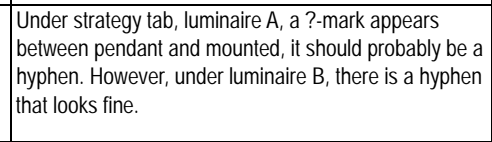 & Specific text & Content & 75 & 1 & 5 & 4.2 & 5 & 5 & 5 & 5 & 46.8 & 43.2 \\
\hline N Miller & NM11 & Lighting Designer & Specialty Market & Barista & \begin{tabular}{|l|} 
Color in the luminaire chart should be 830 , or 835 , not \\
just 83.
\end{tabular} & Specific text & Content & 75 & 1 & 5 & 4.2 & 5 & 5 & 5 & 5 & 46.8 & 43.2 \\
\hline J Tuenge & JT6 & Core Team & Discount Big Box & \begin{tabular}{|l|}
$\begin{array}{l}\text { General - } \\
\text { Perpendicular 21 - } \\
\text { Approach tab }\end{array}$ \\
\end{tabular} & $\begin{array}{l}\text { The text "...80 or greater Refer..." should be broken into } \\
\text { two bullet points. (Typical of others.) }\end{array}$ & Specific text & Content & 75 & 1 & 5 & 4.2 & 5 & 5 & 5 & 5 & 46.8 & 43.2 \\
\hline J Tuenge & JT10 & Core Team & Discount Big Box & $\begin{array}{l}\text { Pop - Over and } \\
\text { Wash 22-Strategy } \\
\text { tab }\end{array}$ & $\begin{array}{l}\text { clunky: "T8 and T5HO lamps have long lives and are } \\
\text { y r readily available are used in this design which } \\
\text { mimimizes maintenance." }\end{array}$ & Specific text & Content & 75 & 1 & 5 & 4.2 & 5 & 5 & 5 & 5 & 46.8 & 43.2 \\
\hline J Tuenge & JT15 & Core Team & Discount Big Box & $\begin{array}{l}\text { Product Display - } \\
\text { Track 23 - Strategy } \\
\text { tab }\end{array}$ & $\begin{array}{l}\text { clunky: "Metat halide lamps compared to tungsten } \\
\text { yhalogen, greatly reduce energy and maintenance." }\end{array}$ & Specific text & Content & 75 & 1 & 5 & 4.2 & 5 & 5 & 5 & 5 & 46.8 & 43.2 \\
\hline $\begin{array}{l}\text { N Miller } \\
\end{array}$ & NM3 & Lighting Designer & Specialty Market & Barista & $\begin{array}{l}\text { The comment in barista text- "the dimmer area } \\
\text { invites.." Ithought that it was referring to a dimmer } \\
\text { area within the barista area, or it could be a dimmer } \\
\text { (controls. }\end{array}$ & Specific text & Content & 75 & 1 & 5 & 4.2 & 5 & 5 & 5 & 5 & 46.8 & 43.2 \\
\hline N Miller & NM8 & Lighting Designer & Specialty Market & Barista & $\begin{array}{l}\text { Say "minimum luminaire efficiciency" rather than } \\
\text { "luminaire efficiency", so that the uninititated know to } \\
\text { use that as a minimum value, not a target. }\end{array}$ & Specific text & Content & 75 & 1 & 5 & 4.2 & 15 & 5 & 5 & 5 & 46.8 & 43.2 \\
\hline R Bartlett & RB13 & Generalist & Grocery Store & $\begin{array}{l}\text { Specialty Vignettes } \\
\text { - Pendants } \\
\text { (cylinders) and } \\
\text { downlights over } \\
\text { merchandise }\end{array}$ & Spproach - second bullet has two periods & Specific text & Content & 75 & 1 & 5 & 4.2 & 5 & 5 & 5 & 5 & 46.8 & 43.2 \\
\hline G Subisak & GS4 & Manufacturer & & \begin{tabular}{|l|} 
Big box discount \\
general sales
\end{tabular} & $\begin{array}{l}\text { Content in approach tab is wrong, hard returns where } \\
\text { there shouldn't be. } 8-00^{\prime \prime} \text { height gondolas should be one } \\
\text { bullet. }\end{array}$ & Specific text & Content & 75 & 3 & 5 & 4.6 & 4 & 5 & 5 & 4.7 & 46.6 & 46.2 \\
\hline LDavis & LD29 & Lighting Designer & Specialty Market & \begin{tabular}{|l} 
Vignette Details- \\
General Sales \\
Luminaires parallel \\
to shelves
\end{tabular} & $\begin{array}{l}\text { correct lamp color temperature (says } 3000 \mathrm{~K} \text { then next } \\
\text { bullet says } 3500 \mathrm{~K} \text {, lamp code is } 835 \text { ) }\end{array}$ & Specific text & Content & 75 & 3 & 5 & 4.6 & 4 & 5 & 5 & 4.7 & 46.6 & 46.2 \\
\hline R Bartlett & RB11 & Generalist & Grocery Store & Specialty Vignettes & $\begin{array}{l}\text { \$ Fluorescent pendants and slot lighting over } \\
\text { merchandise" has no description }\end{array}$ & Specific text & Content & 75 & 2 & 5 & 4.4 & 4 & 5 & 5 & 4.7 & 45.8 & 44.5 \\
\hline J Tuenge & JT14 & Core Team & Discount Big Box & $\begin{array}{l}\text { Product Display - } \\
\text { Track } 23\end{array}$ & Type A mean lumens per watt is N/A? & Specific text & Content & 75 & 2 & 5 & 4.4 & 4 & 5 & 5 & 4.7 & 45.8 & 44.5 \\
\hline J Tuenge & JT14 & Core Team & Discount Big Box & $\begin{array}{l}\text { Product Display - } \\
\text { Track } 23\end{array}$ & Type A mean lumens per watt is N/A? & Specific text & Content & 75 & 2 & 5 & 4.4 & 4 & 5 & 5 & 4.7 & 45.8 & 44.5 \\
\hline J Tuenge & JT9 & Core Team & Discount Big Box & $\begin{array}{l}\text { POS - Over and } \\
\text { Wash } 22\end{array}$ & 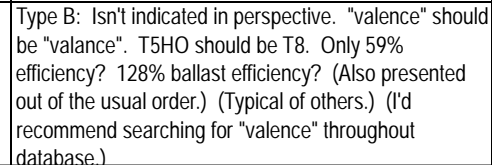 & Specific text & Content & 75 & 1 & 5 & 4.2 & 4 & 5 & 5 & 4.7 & 45.0 & 42.8 \\
\hline
\end{tabular}


Texteg oits

\begin{tabular}{|c|c|c|c|c|c|c|c|c|c|c|c|c|c|c|c|c|c|}
\hline & & & & & & & & & & IMPORTANCE & & & FEA & IBILITY & & RANK & $\begin{array}{ll}\text { VING } \\
\end{array}$ \\
\hline Commenter ID\# & Ref\# & $\begin{array}{l}\text { Commenter } \\
\text { Category }\end{array}$ & $\begin{array}{l}\text { Store Type } \\
\text { (iituplicatia) }\end{array}$ & 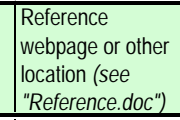 & Comment Description: Issues, Suggestions \& Requests & Action/Solution & Comment Type & $\begin{array}{c}\text { Status } \\
\text { or } \\
\text { Ticket\# }\end{array}$ & $\begin{array}{c}\text { Frequency } \\
(20 \%)\end{array}$ & $\begin{array}{l}\text { Importance of } \\
\text { comment } \\
(40 \%)\end{array}$ & $\begin{array}{c}\text { Sum } \\
(100 \%)\end{array}$ & \begin{tabular}{|c|} 
Ease of \\
Implementation \\
$(30 \%)$
\end{tabular} & $\begin{array}{l}\text { Duration } \\
(40 \%)\end{array}$ & $\begin{array}{c}\text { RiskJ } \\
\text { Complication } \\
(30 \%)\end{array}$ & $\begin{array}{c}\text { Sum } \\
(100 \%)\end{array}$ & $\begin{array}{l}\text { Short Term } \\
\text { (40\%\% Important) } \\
\text { (60\% Feasible) }\end{array}$ & $\begin{array}{l}\text { Long Term } \\
(85 \% \text { Important) } \\
\text { (15\% Feasible) }\end{array}$ \\
\hline J Tuenge & JT12 & Core Team & Discount Big Box & \begin{tabular}{|l} 
POS - Over and \\
Wash 22 - Strategy \\
tab
\end{tabular} & $\begin{array}{l}\text { |'d recommend changing "Daylighting" to "Daylight } \\
\text { Harvesting" to differentiate control scheme from } \\
\text { architecture (tvpical). }\end{array}$ & Specific text & Content & 75 & 1 & 5 & 4.2 & 4 & 5 & 5 & 4.7 & 45.0 & 42.8 \\
\hline HMcKay & HM22 & Lighting Designer & & & Review text content for grammar and typos. & General text & Content & 75 & 4 & 5 & 4.8 & 4 & & 5 & 4.3 & 45.0 & 47.3 \\
\hline J Tuenge & JT48 & Core Team & Grocery & $\begin{array}{l}\text { POS - Pendants w/ } \\
\text { T5 wall }\end{array}$ & Clarify T5 for type C. & Specific text & Content & 75 & 2 & 4 & 3.6 & 5 & 5 & 5 & 5 & 44.4 & 38.1 \\
\hline N Miller & NM10 & Lighting Designer & Specialty Market & Barista & $\begin{array}{l}\text { What do you mean by "ballast efficiency?" Not a metric } \\
\text { I'm familiar with. }\end{array}$ & Specific text & Content & 75 & 1 & 5 & 4.2 & 5 & 4 & 5 & 4.6 & 44.4 & 42.6 \\
\hline J Tuenge & JT57 & Core Team & Specialty Market & Bakery Vignettes & $\begin{array}{l}\text { "Pendants" is misspelled in second description. } \\
\text { Second option should indicate CFL (not CMH) for type } \\
\text { D pendants. }\end{array}$ & Specific text & Content & 75 & 1 & 5 & 4.2 & 4 & & 5 & 4.3 & 42.6 & 42.2 \\
\hline N Miller & NM17 & Lighting Designer & Specialty Market & \begin{tabular}{|l} 
Track lighting \\
highlighting \\
produce (linear \\
fluorescent)
\end{tabular} & You should say a, minimize glare for customers. & Specific text & Content & 75 & 1 & 4 & 3.4 & 5 & 5 & 4 & 4.7 & 41.8 & 36.0 \\
\hline N Miller & NM4 & Lighting Designer & Specialty Market & Barista & $\begin{array}{l}\text { Under criteria, should consistently say "10-20 fc } \\
\text { averaae." }\end{array}$ & Specific text & Content & 75 & 1 & 4 & 3.4 & 5 & 4 & 5 & 4.6 & 41.2 & 35.8 \\
\hline N Miller & NM24 & Lighting Designer & Specialty Market & \begin{tabular}{|l|}
$\begin{array}{l}\text { Track lighting } \\
\text { highlighting } \\
\text { produce (linear } \\
\text { fluorescent) }\end{array}$ \\
\end{tabular} & $\begin{array}{l}\text { Descrivtion for } C \text { is garbled between track and } \\
\text { fluorescent. Hard to tell what is what. Which } \\
\text { description applies to which fixture. }\end{array}$ & Specific text & Content & 75 & 1 & 4 & 3.4 & 5 & 4 & 5 & 4.6 & 41.2 & 35.8 \\
\hline B Manning & BM9 & $?$ & Grocery & \begin{tabular}{|l|} 
Pharmacy \\
\end{tabular} & \begin{tabular}{|l} 
Note the order of the options presented differs from \\
'General SSless ShortA Aises'
\end{tabular} & Specific text & Content & 75 & 2 & 4 & 3.6 & 4 & 5 & 4 & 4.4 & 40.8 & 37.2 \\
\hline B Manning & BM10 & $?$ & Grocery & $\begin{array}{l}\text { General Sales: } \\
\text { Long Aisles }\end{array}$ & $\begin{array}{l}\text { Note the orded of of the optitins presented differs from } \\
\text { 'General Sales: Lon Aisles' }\end{array}$ & Specific text & Content & 75 & 2 & 4 & 3.6 & 4 & 5 & 4 & 4.4 & 40.8 & 37.2 \\
\hline H McKay & HM8 & Lighting Designer & Big Box & $\begin{array}{l}\text { Track Luminaires } \\
\text { highlighting } \\
\text { produce }\end{array}$ & \begin{tabular}{|l} 
Under Approach. Typo, "products." Should be "product \\
cases."
\end{tabular} & Specific text & Content & 75 & 1 & 3 & 2.6 & 5 & 5 & 5 & 5 & 40.4 & 29.6 \\
\hline TBetz & TB12 & $?$ & & $\begin{array}{l}\text { Luminaire } \\
\text { Schedule }\end{array}$ & $\begin{array}{l}\text { Use of the word "vignette" does not seem appropriate. } \\
\text { Perrhaps "design" or "layout" would work better. }\end{array}$ & Specific text & Content & 75 & 2 & 3 & 2.8 & 4 & 5 & 5 & 4.7 & 39.4 & 30.9 \\
\hline K Abernathy & KA21 & Lighting Designer & & Energy Summary & $\begin{array}{l}\text { Intro page- "Other resources include lighting } \\
\text { professionals.." Do you want these organizations to } \\
\text { be called resources? }\end{array}$ & Specific text & Content & 75 & 1 & 3 & 2.6 & 5 & & 4 & 4.7 & 38.6 & 29.2 \\
\hline B Hamilton & $\mathrm{BH} 13$ & Core Team & Specialty Market & $\begin{array}{l}\text { Produce, Track } \\
\text { Lighting } \\
\text { Highlighting } \\
\text { Produce (Linear } \\
\text { Flurosescent) }\end{array}$ & $\begin{array}{l}\text { Some of the vigigentes have the same title and the } \\
\text { difference between them needs to be clarified in the } \\
\text { tititle. You can only tell by reading the blurb on the } \\
\text { vignette list. (lamping differences) }\end{array}$ & Specific text & Content & 75 & 3 & 3 & 3 & 4 & & 5 & 4.3 & 37.8 & 32.0 \\
\hline
\end{tabular}




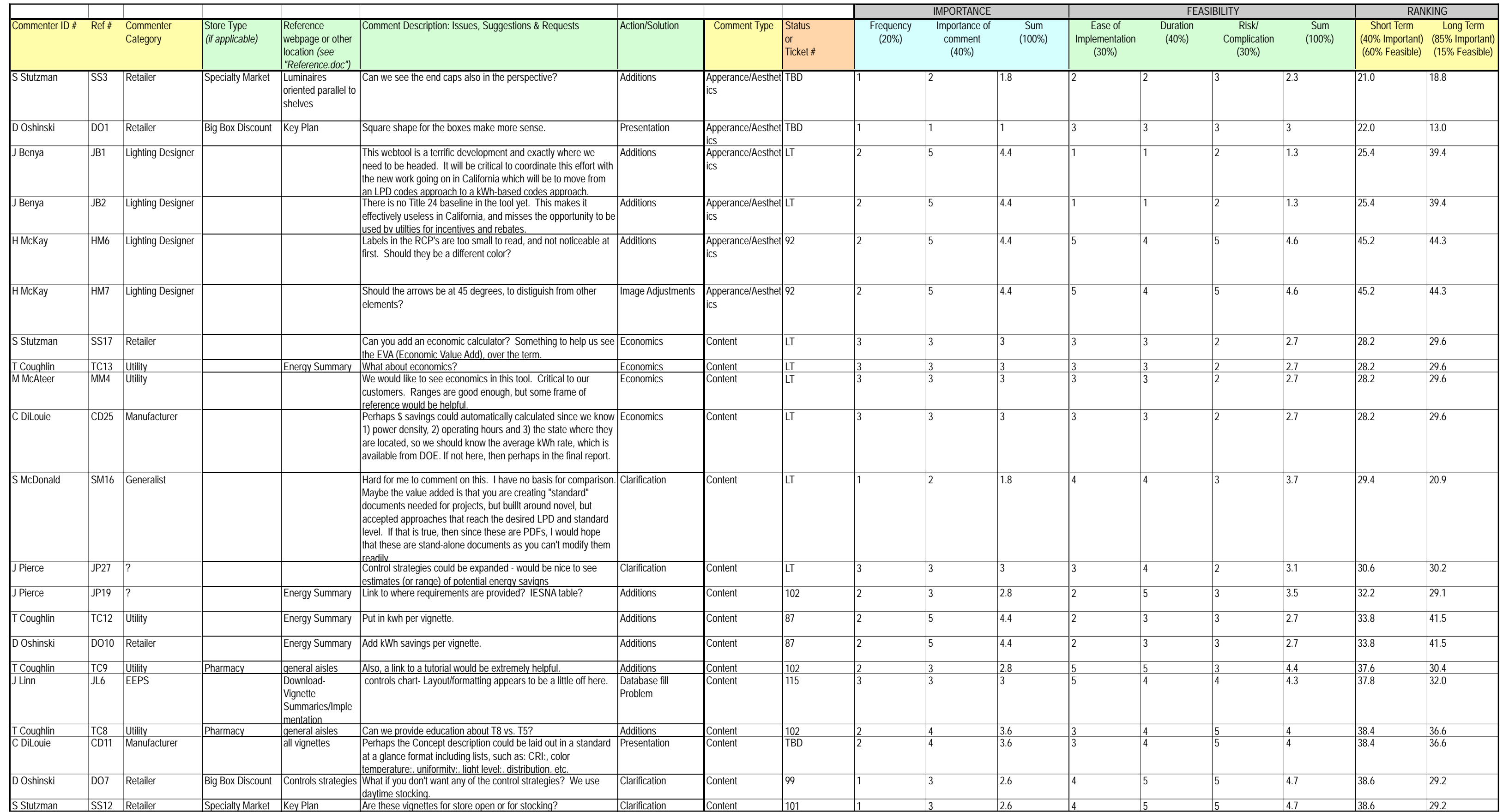




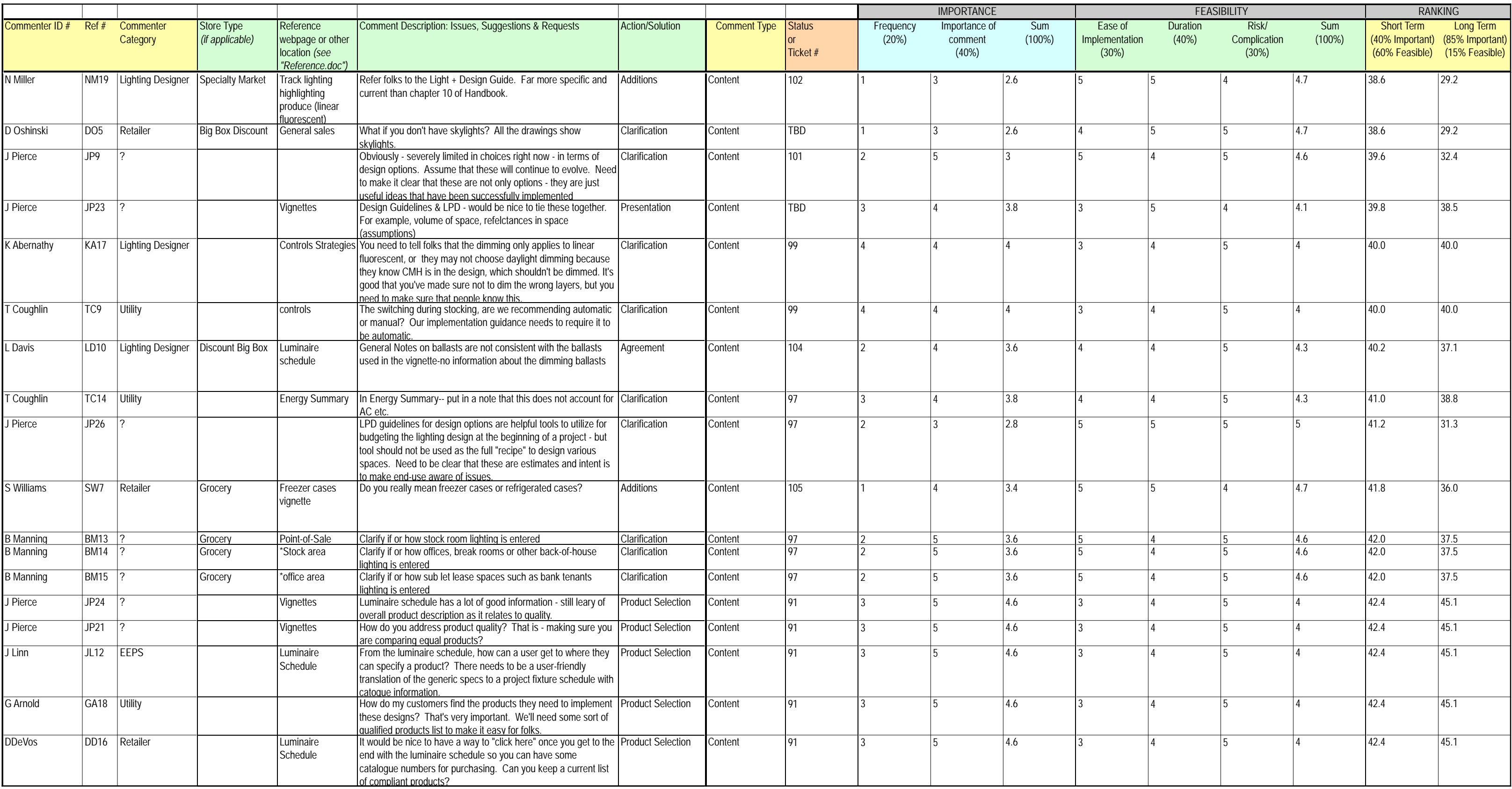




\begin{tabular}{|c|c|c|c|c|c|c|c|c|c|c|c|c|c|c|c|c|c|}
\hline & & & & & & & & & & IMPORTANCE & & & & SIBILITY & & & JIING \\
\hline Commenter ID \# & Ref\# & $\begin{array}{l}\text { Commenter } \\
\text { Category }\end{array}$ & $\begin{array}{l}\text { Store Type } \\
\text { (if p pplicabla) }\end{array}$ & 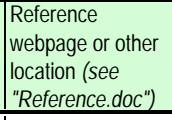 & Comment Description: Issues, Suggestions \& Requests & Action/Solution & Comment Type & \begin{tabular}{|l} 
Status \\
or \\
Ticket\#
\end{tabular} & $\begin{array}{c}\text { Frequency } \\
(20 \%)\end{array}$ & $\begin{array}{l}\text { Impoottance of } \\
\text { comment } \\
(40 \%)\end{array}$ & $\begin{array}{l}\text { Sum } \\
(100 \%)\end{array}$ & $\begin{array}{l}\text { Ease of } \\
\text { Implementation } \\
(30 \%)\end{array}$ & $\begin{array}{c}\text { Duration } \\
(40 \%)\end{array}$ & $\begin{array}{c}\text { Riskl } \\
\text { Complication } \\
(30 \%)\end{array}$ & $\begin{array}{l}\text { Sum } \\
(100 \%)\end{array}$ & \begin{tabular}{|c|c|} 
Short Term \\
$(40 \% \%$ Important) \\
(60\%\% Feasible)
\end{tabular} & $\begin{array}{c}\text { Long Term } \\
\left(\begin{array}{c}\text { (85\% I mportant) } \\
\text { (15\% Feasible) }\end{array}\right.\end{array}$ \\
\hline M Hershman & & & & specialty & 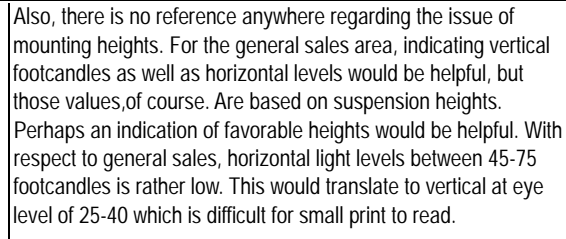 & |Clarification & Content & 96 & 4 & 4 & 4 & 4 & 5 & 4 & 4.4 & 42.4 & 40.6 \\
\hline G Subisak & GS6 & Manufacturer & & \begin{tabular}{|l} 
Big box discount \\
general sales
\end{tabular} & $\begin{array}{l}\text { Does the retailer like the suspension length? Are the fixtures too } \\
\text { low? }\end{array}$ & Additions & Content & 96 & 4 & 4 & 4 & 4 & 5 & 4 & 4.4 & 42.4 & 40.6 \\
\hline J Tuenge & JT11 & Core Team & Discount Big Box & $\begin{array}{l}\text { POS - Over and } \\
\text { Wash } 22\end{array}$ & $\begin{array}{l}\text { Type A has dimming ballast, contrary to Strategy and Controls } \\
\text { tabs. }\end{array}$ & Agreement & Content & 104 & 2 & 4 & 3.6 & 4 & 5 & 5 & 4.7 & 42.6 & 37.7 \\
\hline JPierce & JP22 & $?$ & & Vignettes & Maintenance issues are a nice addition - need to elaborate & Presentation & Content & 95 & 1 & 5 & 4.2 & 4 & 5 & 5 & 4.7 & 45.0 & 42.8 \\
\hline TBetz & TB9 & ? & & Energy Summary & $\begin{array}{l}\text { The Vignette Summary "Maintenance Issues" section should be } \\
\text { more descriptive regarding cleaning of fuminaires. A "damm pag" } \\
\text { is vague. A note should be added to consult manufacturer } \\
\text { guidelinins for cleaning to ensure fixture longevity and maintain } \\
\text { warranties. }\end{array}$ & Clarification & Content & 95 & 1 & 5 & 4.2 & 4 & 5 & 5 & 4.7 & 45.0 & 42.8 \\
\hline $\mathrm{J}$ Tuenge & JT32 & Core Team & Grocery & $\begin{array}{l}\text { Generall/Short- } \\
\text { Perpendicular }\end{array}$ & Type B not indicated in perspective. & Missing/Formatting & Content & 90 & 2 & 5 & 4.4 & 5 & 4 & 5 & 4.6 & 45.2 & 44.3 \\
\hline J Tuenge & JT34 & Core Team & Grocery & $\begin{array}{l}\text { Generall/Short - } \\
\text { Cantilevered }\end{array}$ & Type D not indicated in perspective. & Missing/Formatting & Content & 90 & 2 & 5 & 4.4 & 5 & 4 & 5 & 4.6 & 45.2 & 44.3 \\
\hline J Tuenge & JT43 & Core Team & Grocery & Bakery - Lensed & $\begin{array}{l}\text { Type B luminaire shown in perspective is directlindirect, not } \\
\text { lensed. }\end{array}$ & Missing/Formatting & Content & 90 & 2 & 5 & 4.4 & 5 & 4 & 5 & 4.6 & 45.2 & 44.3 \\
\hline J Tuenge & JT44 & Core Team & Grocery & $\begin{array}{l}\text { Bakery - Baskets } \\
\text { W/ pendants }\end{array}$ & $\begin{array}{l}\text { Type C luminaire shown in perspective is lensed, not } \\
\text { directlindirect. }\end{array}$ & Missing/Formatting & Content & 90 & 2 & 5 & 4.4 & 5 & 4 & 5 & 4.6 & 45.2 & 44.3 \\
\hline J Tuenge & JT45 & Core Team & Grocery & $\begin{array}{l}\text { Bakery - Lensed } \\
\text { w/ pendants }\end{array}$ & $\begin{array}{l}\text { Type C luminaire shown in perspective is directlindirect, not } \\
\text { lensed. }\end{array}$ & Missing/Formatting & Content & 90 & 2 & 5 & 4.4 & 5 & 4 & 5 & 4.6 & 45.2 & 44.3 \\
\hline J Tuenge & JT35 & Core Team & Grocery & \begin{tabular}{|l|} 
General/Long - \\
Parallel
\end{tabular} & Skylights not shown in perspective. & Missing/Formatting & Content & 90 & 2 & 5 & 4.4 & 5 & 4 & 5 & 4.6 & 45.2 & 44.3 \\
\hline J Tuenge & JT35 & Core Team & Grocery & \begin{tabular}{|l} 
Generall/long - \\
Parallel
\end{tabular} & Incorrect housingllocation shown for type B in perspective. & Missing/Formatting & Content & 90 & 2 & 5 & 4.4 & 5 & 4 & 5 & 4.6 & 45.2 & 44.3 \\
\hline J Tuenge & JT37 & Core Team & Grocery & $\begin{array}{l}\text { lenerall/Long - } \\
\text { Cantilevered }\end{array}$ & Type C in perspective should be type D. & Missing/Formatting & Content & 90 & 2 & 5 & 4.4 & 5 & 4 & 5 & 4.6 & 45.2 & 44.3 \\
\hline J Tuenge & JT41 & Core Team & Grocery & $\begin{array}{l}\text { Pharmacy - } \\
\text { Pendants }\end{array}$ & Delete celing grid in perspective. & Missing/Formatting & Content & 90 & & 5 & 4.4 & 5 & 4 & 5 & 4.6 & 45.2 & 44.3 \\
\hline
\end{tabular}




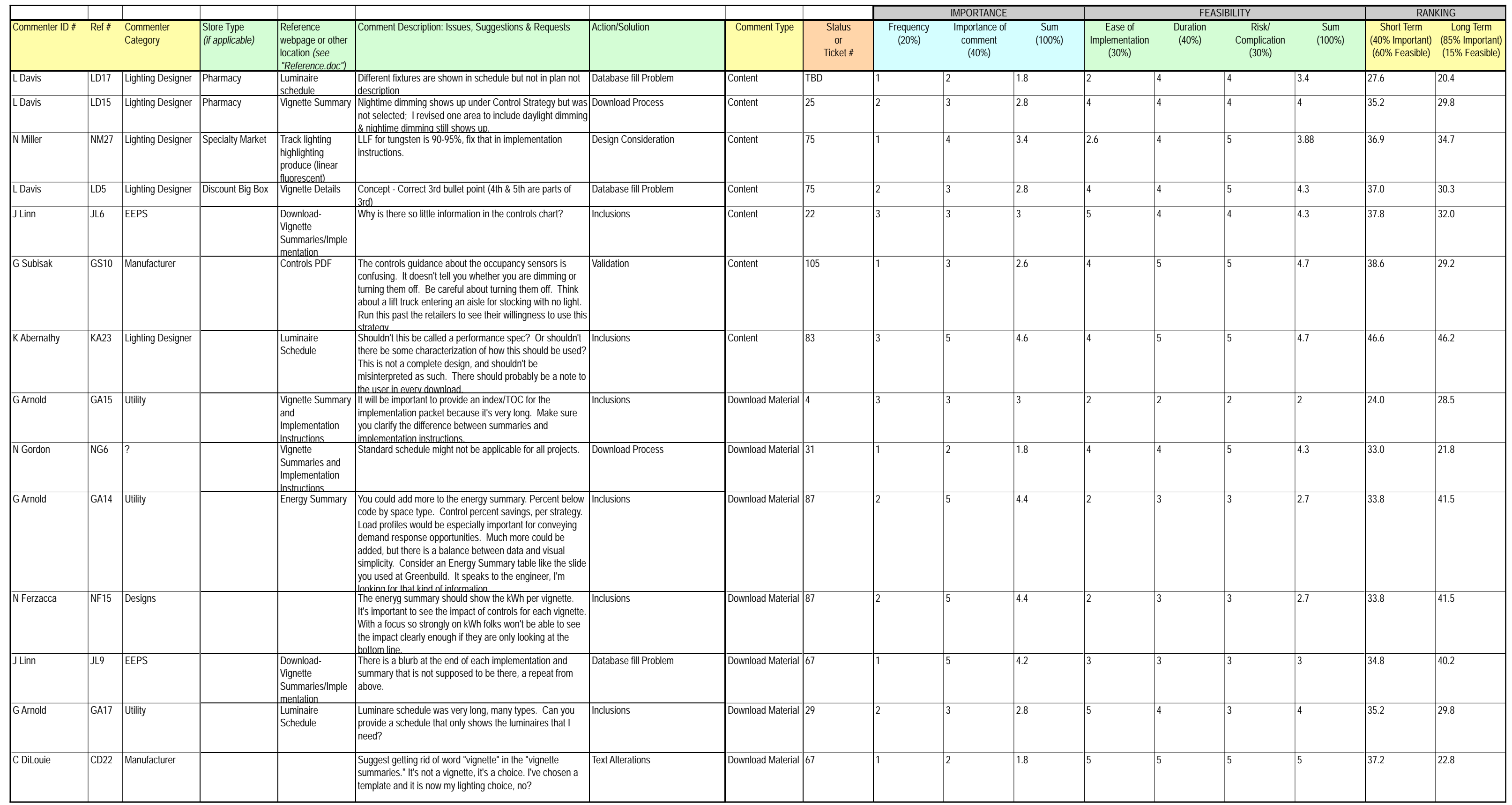




\begin{tabular}{|c|c|c|c|c|c|c|c|c|c|c|c|c|c|c|c|c|c|}
\hline & I & & & & & & & & & IMPORTANCE & & & & IBLLITY & & & KING \\
\hline Commenter ID \# & Ref \# & $\begin{array}{l}\text { Commenter } \\
\text { Category }\end{array}$ & $\begin{array}{l}\text { Store Type } \\
(i f a p l i c a b l e)\end{array}$ & 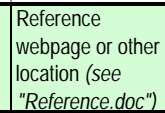 & Comment Description: Issues, Suggestions \& Requests & Action/Solution & Comment Type & $\begin{array}{c}\text { Status } \\
\text { or } \\
\text { Ticket\# }\end{array}$ & $\begin{array}{l}\text { Frequency } \\
(20 \%)\end{array}$ & $\begin{array}{c}\text { Importance of } \\
\text { comment } \\
(40 \%)\end{array}$ & $\begin{array}{c}\text { Sum } \\
(100 \%)\end{array}$ & $\begin{array}{l}\text { Ease of } \\
\text { Implementation } \\
(30 \%)\end{array}$ & $\begin{array}{c}\text { Duration } \\
(40 \%)\end{array}$ & $\begin{array}{c}\text { Risk/ } \\
\text { Complication } \\
(30 \%)\end{array}$ & $\begin{array}{l}\text { Sum } \\
(100 \%)\end{array}$ & $\begin{array}{l}\text { Short Term } \\
\text { (40\% Important) } \\
\text { (60\% Feasible) }\end{array}$ & $\begin{array}{l}\text { Long Term } \\
\text { (85\% Important) } \\
\text { (15\% Feasible) }\end{array}$ \\
\hline G Subisak & GS22 & Manufacturer & & \begin{tabular}{|l|} 
Vignette \\
Summaries \& \\
Implementation \\
Instructions
\end{tabular} & $\begin{array}{l}\text { The spacing dimensions in the implementation instructions } \\
\text { are too small to read. }\end{array}$ & Database fill Problem & Download Material & 114 & $\left.\right|^{2}$ & 4 & 3.6 & 3 & 4 & 5 & 4 & 38.4 & 36.6 \\
\hline C Dilouie & CD24 & Manufacturer & & & 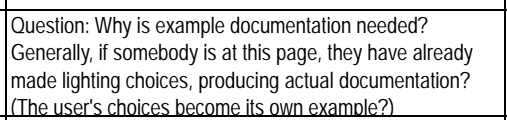 & Inclusions & Download Material & 85 & 2 & 3 & 2.8 & 5 & 5 & 5 & 5 & 41.2 & 31.3 \\
\hline B Hamilton & BH29 & Core Team & Specialty Market & \begin{tabular}{|l} 
Luminaire \\
Schedule
\end{tabular} & 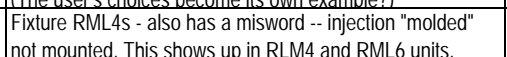 & Text Alterations & Download Material & 75 & 1 & 4 & 3.4 & 4 & 5 & 5 & 4.7 & 41.8 & 36.0 \\
\hline G Subisak & GS20 & Manufacturer & & \begin{tabular}{|l|} 
Vignette \\
Summaries \& \\
IInplementation \\
Instructions
\end{tabular} & 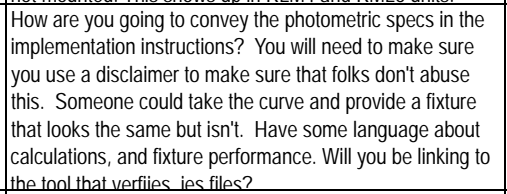 & |inclusions & Download Material & 91 & 3 & 5 & 4.6 & 3 & 4 & 5 & 4 & 42.4 & 45.1 \\
\hline G Subisak & GS21 & Manufacturer & & \begin{tabular}{|l|} 
Vignette \\
Summaries \& \\
IInplementation \\
Instructions
\end{tabular} & 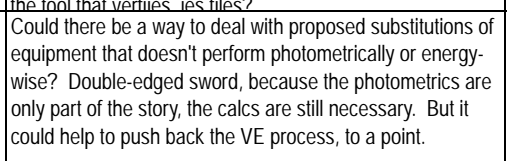 & Inclusions & Download Material & 91 & 3 & 5 & 4.6 & 3 & 4 & 5 & 4 & 42.4 & 45.1 \\
\hline JLinn & JL10 & EEPS & & \begin{tabular}{|l} 
Download- \\
Vignette \\
Summaries/lmple \\
mentation
\end{tabular} & Shows null in one of the Quicktips sections. & Database fill Problem & Download Material & 113 & 1 & 5 & 4.2 & 4 & 4 & 5 & 4.3 & 42.6 & 42.2 \\
\hline GArnold & GA16 & Utility & & \begin{tabular}{|l} 
Luminaire \\
Schedule
\end{tabular} & 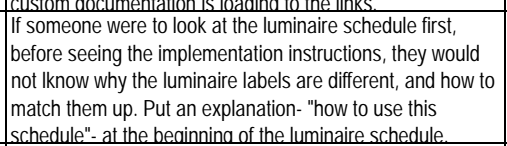 & Inclusions & Download Material & 83 & 3 & 5 & 4.6 & 4 & 5 & 5 & 4.7 & 46.6 & 46.2 \\
\hline JLinn & JL11 & EEPS & & \begin{tabular}{|l|} 
Download- \\
Vignette \\
Summaries/lmple \\
mentation
\end{tabular} & 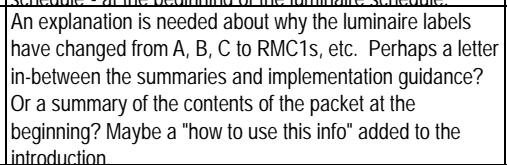 & Inclusions & Download Material & 83 & 3 & 5 & 4.6 & 4 & 5 & 5 & 4.7 & 46.6 & 46.2 \\
\hline B Manning & BM23 & $?$ & N/A & & 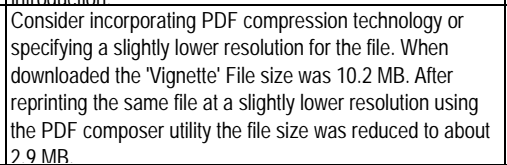 & Download Process & \begin{tabular}{|l} 
Download \\
Materials
\end{tabular} & 114 & 2 & 3 & 2.8 & 2 & 2 & 2 & 2 & 23.2 & 26.8 \\
\hline J Tuenge & JT22 & Core Team & Discount Big Box & \begin{tabular}{|l} 
PDF-Vignette \\
Summaries and \\
Implementatition \\
Instructions
\end{tabular} & $\begin{array}{l}\text { If controls are to be listed for each vignette they should be } \\
\text { specific to each vignette, not simply the same set repeated } \\
\text { over and over. }\end{array}$ & Inclusions & \begin{tabular}{|l} 
Download \\
Materials
\end{tabular} & 80 & 1 & 4 & 3.4 & 2 & 2 & 2 & 2 & 25.6 & 31.9 \\
\hline J Tuenge & JT23 & Core Team & Discount Big Box & \begin{tabular}{|l} 
PDF-Vignette \\
Summaries and \\
Implementation \\
Instructions \\
\end{tabular} & |"Vignette Implementation" header isn't indented. & Database fill Problem & \begin{tabular}{|l} 
Download \\
Materials
\end{tabular} & 68 & 1 & 3 & 2.6 & 5 & 5 & & 5 & 40.4 & 29.6 \\
\hline
\end{tabular}




\begin{tabular}{|c|c|c|c|c|c|c|c|c|c|c|c|c|c|c|c|c|c|}
\hline & & & & & & & & & & $\begin{array}{l}\text { IMPORTANCE } \\
\end{array}$ & & & & 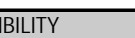 & & & NIING \\
\hline 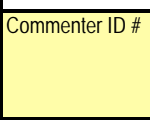 & Ref\# & $\begin{array}{l}\text { Commenter } \\
\text { Category }\end{array}$ & $\begin{array}{l}\text { Store Type } \\
\text { (iitiplicatla) }\end{array}$ & 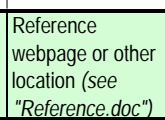 & Comment Description: Issues, Suggestions \& Requests & Action/Solution & Comment Type & $\begin{array}{c}\text { Status } \\
\text { or } \\
\text { Ticket\# }\end{array}$ & $\begin{array}{c}\text { Frequency } \\
(20 \%)\end{array}$ & $\begin{array}{c}\text { Importance of } \\
\text { comment } \\
(40 \%)\end{array}$ & $\begin{array}{c}\text { Sum } \\
(100 \%)\end{array}$ & $\begin{array}{c}\text { Ease of } \\
\text { Implementation } \\
(30 \%)\end{array}$ & $\begin{array}{l}\text { Duration } \\
(40 \%)\end{array}$ & $\begin{array}{l}\text { Riskl } \\
\text { Complication } \\
(30 \%)\end{array}$ & $\begin{array}{c}\text { Sum } \\
(100 \%)\end{array}$ & $\begin{array}{l}\text { Short Term } \\
\text { (40\%\% Important) } \\
\text { (60\%\% Feasible) }\end{array}$ & $\begin{array}{c}\text { Long Term } \\
\left(\begin{array}{l}\text { (85\% Important) } \\
(15 \% \text { Feasible) }\end{array}\right.\end{array}$ \\
\hline J Tuenge & JT21 & Core Team & Discount Big Box & $\begin{array}{l}\text { PDF-Vignette } \\
\text { Summaries and } \\
\text { Implementation } \\
\text { Instructions }\end{array}$ & 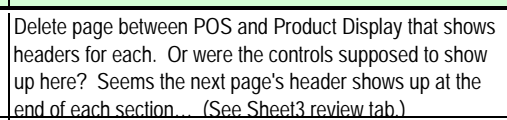 & Database fill Problem & \begin{tabular}{|l} 
Download \\
Materials
\end{tabular} & 75 & 1 & 5 & 4.2 & 4 & 4 & 5 & 4.3 & 42.6 & 42.2 \\
\hline J Tuenge & JT25 & Core Team & Discount Big Box & 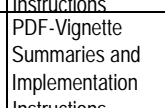 & 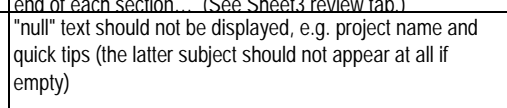 & Database fill Problem & \begin{tabular}{|l} 
Download \\
Materials
\end{tabular} & 113 & 1 & 5 & 4.2 & 4 & 4 & 5 & 4.3 & 42.6 & 42.2 \\
\hline J Tuenge & JT26 & Core Team & Discount Big Box & $\begin{array}{l}\text { PDSFF-Vignette } \\
\text { Summaries and } \\
\text { Implementation } \\
\text { Instructions }\end{array}$ & Luminaire labels in figures changed from $A$ or B to RBLxx. & Agreement & \begin{tabular}{|l} 
Download \\
Materials
\end{tabular} & 83 & 3 & 5 & 4.6 & 4 & 5 & 5 & 4.7 & 46.6 & 46.2 \\
\hline J Tuenge & JT18 & Core Team & Discount Big Box & $\begin{array}{l}\text { Energy Summary } \\
\text { PDF }\end{array}$ & 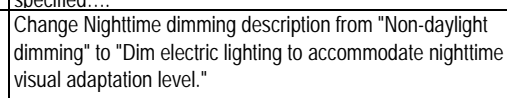 & Text Alterations & 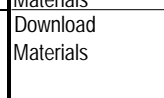 & 25 & 1 & 5 & 4.2 & 5 & 5 & 5 & 5 & 46.8 & 43.2 \\
\hline J Tuenge & JT20 & Core Team & Discount Big Box & $\begin{array}{l}\text { Energy Summary } \\
\text { PDF }\end{array}$ & $\begin{array}{l}\text { Change "Occupancy Sensors" description from "Occupancy } \\
\text { Sensors" to "Dim or swith electric lighting when associated } \\
\text { areas are vacant." }\end{array}$ & Text Alterations & \begin{tabular}{|l} 
Download \\
Materials
\end{tabular} & 25 & 1 & 5 & 4.2 & 5 & 5 & 5 & 5 & 46.8 & 43.2 \\
\hline J Tuenge & JT24 & Core Team & Discount Big Box & \begin{tabular}{|l} 
PDF-Vignette \\
Summaries and \\
Implementation \\
Inctrotion
\end{tabular} & $\begin{array}{l}\text { Deletet quotes at beginning and end of Assumptions and } \\
\text { delete "a" rrom "design include a dimensions" }\end{array}$ & Text Alterations & \begin{tabular}{|l} 
Download \\
Materials
\end{tabular} & 69 & 1 & 5 & 4.2 & 5 & 5 & 5 & 5 & 46.8 & 43.2 \\
\hline J Tuenge & JT19 & Core Team & Discount Big Box & $\begin{array}{l}\text { Energy Summary } \\
\text { PDF }\end{array}$ & Is "Switching during stocking" really "Prel/Post Stocking"?... & Text Alterations & \begin{tabular}{|l} 
Download \\
Materials
\end{tabular} & 75 & 1 & 5 & 4.2 & 5 & 5 & 5 & 5 & 46.8 & 43.2 \\
\hline J Tuenge & JT17 & Core Team & Discount Big Box & \begin{tabular}{|l} 
Energy Summary \\
PDF
\end{tabular} & PDF filename is defautled incorrectly to "IImplementation" & Download Process & $\begin{array}{l}\text { Download } \\
\text { Materials }\end{array}$ & 114 & 2 & 5 & 4.4 & 5 & 5 & 5 & 5 & 47.6 & 44.9 \\
\hline G Arnold & GA1 & Utility & & Downloads & 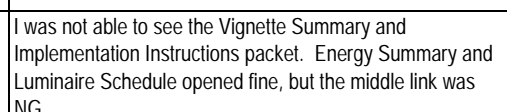 & Download Process & Functionality & TBD & 1 & 4 & 3.4 & 4 & 4 & 4 & 4 & 37.6 & 34.9 \\
\hline
\end{tabular}




\begin{tabular}{|c|c|c|c|c|c|c|c|c|c|c|c|c|c|c|c|c|c|}
\hline & & & & & & & & & & IMPORTANCE & & & & IBILITY & & RANK & IKING \\
\hline Commenter ID \# & Ref\# & $\begin{array}{l}\text { Commenter } \\
\text { Category }\end{array}$ & $\begin{array}{l}\text { Store Type } \\
\text { (iti p plicis ble }\end{array}$ & 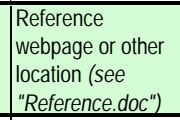 & \begin{tabular}{|l|} 
Comment Description: Issues, Suggestions \& Requests \\
\end{tabular} & Action/Solution & \begin{tabular}{|l|} 
Comment Type \\
\end{tabular} & $\begin{array}{l}\text { Status } \\
\text { or } \\
\text { Ticket \# }\end{array}$ & $\begin{array}{l}\text { Frequency } \\
(20 \%)\end{array}$ & $\begin{array}{l}\text { Importance of } \\
\text { comment } \\
(40 \%)\end{array}$ & $\begin{array}{c}\text { Sum } \\
(100 \%)\end{array}$ & $\begin{array}{c}\text { Ease of } \\
\text { Implementation } \\
(30 \%)\end{array}$ & $\begin{array}{l}\begin{array}{c}\text { Duration } \\
(40 \%)\end{array} \\
\text { (a) }\end{array}$ & $\begin{array}{c}\text { Risk } / \\
\text { Complication } \\
(30 \%)\end{array}$ & $\begin{array}{l}\text { Sum } \\
(100 \%)\end{array}$ & $\begin{array}{l}\text { Short Term } \\
\text { (40\% Important) } \\
\text { (60\% Feasible) }\end{array}$ & $\begin{array}{c}\text { Long Term } \\
\text { (85\% Important) } \\
\text { (15\% Feasible) }\end{array}$ \\
\hline VBarr & VB5 & State & & & 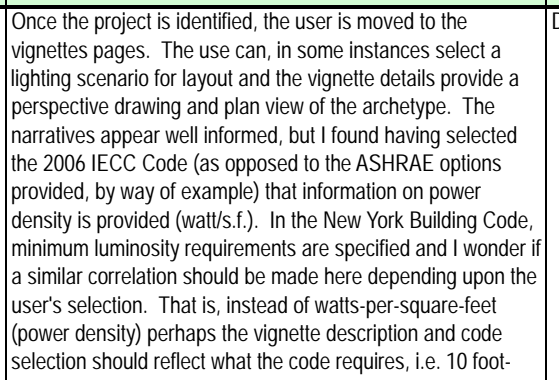 & Design Consideration & Content & LT & 1 & 2 & 1.8 & 2 & & 2 & 2.4 & 21.6 & 18.9 \\
\hline L Davis & LD34 & Lighting Designer & Specialty Market & $\begin{array}{l}\text { Vignette Details - } \\
\text { Barista }\end{array}$ & 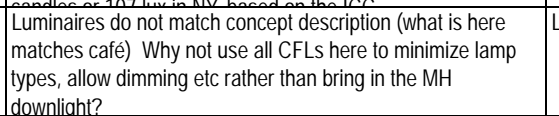 & Luminaire Changes & Content & 112 & 1 & 3 & 2.6 & 2 & & 3 & 2.3 & 24.2 & 25.6 \\
\hline L Davis & LD18 & Lighting Designer & Pharmacy & $\begin{array}{l}\text { Luminaire } \\
\text { schedule }\end{array}$ & $\begin{array}{l}\text { Oocc Sensor strategy chosen - fixtures shown with dimming } \\
\text { ballasts \& Is ballasts - better to use PS ballasts with the latest } \\
\text { ballasts now available. }\end{array}$ & Luminaire Changes & Content & 112 & 1 & 3 & 2.6 & 2 & & 3 & 2.3 & 24.2 & 25.6 \\
\hline L Davis & LD27 & Lighting Designer & Grocery Store & \begin{tabular}{|l|} 
Luminaire \\
schedule
\end{tabular} & 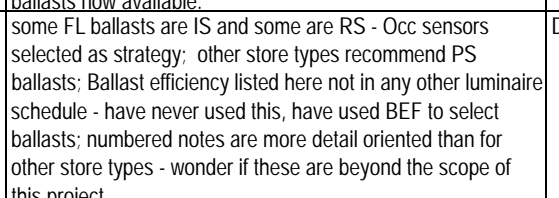 & Design Consideration & Content & 112 & 1 & 3 & 2.6 & 2 & & 3 & 2.3 & 24.2 & 25.6 \\
\hline N Miller & NM2 & Lighting Designer & Specialty Market & Barista & 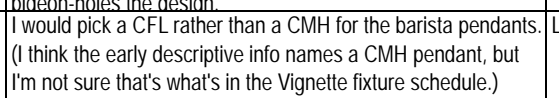 & Luminaire Changes & Content & 112 & 1 & 3 & 2.6 & 2 & & 3 & 2.3 & 24.2 & 25.6 \\
\hline N Miller & NM7 & Lighting Designer & Specialty Market & Barista & \begin{tabular}{|l} 
Take a look at the luminous linear pendant fixture, might be too \\
bright, not the right distribution to produce the lumpy-lighting
\end{tabular} & Luminaire Changes & Content & 112 & 1 & 3 & 2.6 & 2 & & 3 & 2.3 & 24.2 & 25.6 \\
\hline N Miller & NM21 & Lighting Designer & Specialty Market & \begin{tabular}{|l|} 
Track lighting \\
highlighting \\
produce (linear \\
fluorescent)
\end{tabular} & $\begin{array}{l}\text { Why dowe want a spot diststibution? Should be a flood, } \\
\text { especially since most CMH floods are only } 25 \text { to } 30 \text { degrees } \\
\text { anyway. }\end{array}$ & Luminaire Changes & Content & 112 & 1 & 3 & 2.6 & 2 & & 3 & 2.3 & 24.2 & 25.6 \\
\hline N Miller & NM9 & Lighting Designer & Specialty Market & 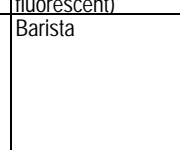 & 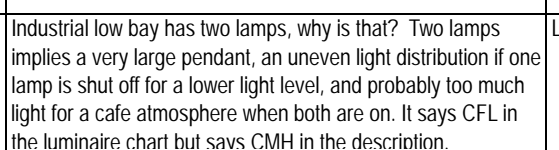 & Luminaire Changes & Content & 112 & 1 & 3 & 2.6 & 2 & & 3 & 2.3 & 24.2 & 25.6 \\
\hline N Miller & NM22 & Lighting Designer & Specialty Market & \begin{tabular}{|l|} 
Track lighting \\
highlighting \\
produce (linear \\
fluorescent)
\end{tabular} & 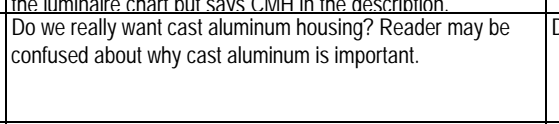 & Design Considerations & Content & 112 & 1 & 3 & 2.6 & 2 & & 3 & 2.3 & 24.2 & 25.6 \\
\hline M Hershman & & & grocery & general sales & 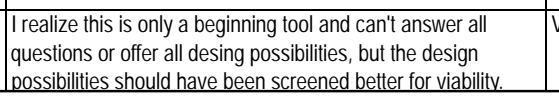 & Validation & Content & TBD & & 3 & 2.6 & 3 & & 2 & 2.3 & 24.2 & 25.6 \\
\hline
\end{tabular}




\begin{tabular}{|c|c|c|c|c|c|c|c|c|c|c|c|c|c|c|c|c|c|}
\hline & & & & & & & & & & IMPORTANCE & & & & IBILITY & & RANK & IKING \\
\hline Commenter ID \# & Ref\# & $\begin{array}{l}\text { Commenter } \\
\text { Category }\end{array}$ & $\begin{array}{l}\text { Store Type } \\
\text { (iti p plicibile) }\end{array}$ & 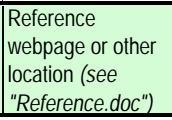 & Comment Description: Issues, Suggestions \& Requests & Action/Solution & \begin{tabular}{|l|} 
Comment Type \\
\end{tabular} & $\begin{array}{l}\text { Status } \\
\text { or } \\
\text { Ticket \# }\end{array}$ & $\begin{array}{c}\text { Frequency } \\
(20 \%)\end{array}$ & $\begin{array}{c}\text { Importance of } \\
\text { comment } \\
(40 \%)\end{array}$ & $\begin{array}{c}\text { Sum } \\
(100 \%)\end{array}$ & $\begin{array}{c}\text { Ease of } \\
\text { Implementation } \\
(30 \%)\end{array}$ & $\begin{array}{l}\begin{array}{c}\text { Duration } \\
(40 \%)\end{array} \\
\text { (a) }\end{array}$ & $\begin{array}{c}\text { Risk } / \\
\text { Complication } \\
(30 \%)\end{array}$ & $\begin{array}{c}\text { Sum } \\
(100 \%)\end{array}$ & $\begin{array}{l}\text { Short Term } \\
\text { (40\% Important) } \\
\text { (60\% Feasible) }\end{array}$ & $\begin{array}{c}\text { Long Term } \\
\text { (85\% Important) } \\
\text { (15\% Feasible) }\end{array}$ \\
\hline J Pierce & JP10 & $?$ & & & $\begin{array}{l}\text { Would be nice to have a custom option - build your own space. } \\
\text { There are items included that may or may not be in each store. }\end{array}$ & Webtool changes & Content & 62 & 3 & 4 & 3.8 & 2 & ${ }^{2}$ & 2 & 2 & 27.2 & 35.3 \\
\hline N Ferzacca & NF9 & Designs & Grocery & Grocery Key Plan & $\begin{array}{l}\text { Specialty seems to be a catch all phrase, but it's only one } \\
\text { design, and it's not entirely clear what you mean by it. What } \\
\text { about adding an "other" space so you can add designs or } \\
\text { areas that arent't represented in your cey plan? What about } \\
\text { back of house spaces? YOu need to give a way to at least } \\
\text { entert the energy load and SFage info so the energy projection } \\
\text { inn't skewewed }\end{array}$ & More Space Types & Content & 62 & 3 & 4 & 3.8 & 2 & 2 & 2 & 2 & 27.2 & 35.3 \\
\hline S Stutzman & SS7 & Retailer & Specialty Market & Key Plan & 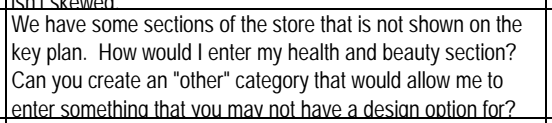 & More Space Types & Content & 62 & 3 & 4 & 3.8 & 2 & 2 & 2 & 2 & 27.2 & 35.3 \\
\hline N Ferzacca & NF17 & Designs & & & $\begin{array}{l}\text { You should be modeling the savings, plus or minus, related to } \\
\text { toplighting whole building analysis will be eneeded }\end{array}$ & Daylighting Guidance & Content & LT & 3 & 4 & 3.8 & 2 & 2 & 3 & 2.3 & 29.0 & 35.8 \\
\hline VBarr & VB10 & State & & & 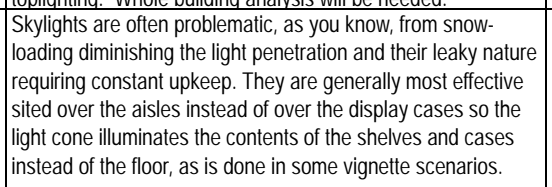 & Daylighting Guidance & Content & 106 & 1 & 3 & 2.6 & 3 & 3 & 4 & 3.3 & 30.2 & 27.1 \\
\hline L Davis & LD8 & Lighting Designer & \begin{tabular}{|l|} 
Discount Big Box \\
\end{tabular} & Vignette Details & 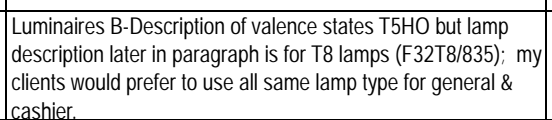 & Design Consideration & Content & 112 & 1 & 3 & 2.6 & 3 & 4 & 4 & 3.7 & 32.6 & 27.7 \\
\hline N Miller & NM26 & Lighting Designer & Specialty Market & \begin{tabular}{|l|} 
Track lighting \\
highlighting \\
produce (linear \\
fluorescent)
\end{tabular} & $\begin{array}{l}\text { Casn wer put the remote ballast in the canopy so it's not } \\
\text { remote? Remote ballasts are a pain in the neck for a } \\
\text { commercial installation. }\end{array}$ & Design Considerations & Content & 112 & 1 & 3 & 2.6 & 3 & 4 & 4 & 3.7 & 32.6 & 27.7 \\
\hline D Oshinski & DO9 & Retailer & Big Box Discount & Controls strategies & $\begin{array}{l}\text { We have had trouble with skylights. Leaking at first. But more } \\
\text { importantly, the racks are so high, and they will move around } \\
\text { over time, that we end up with racks under skylights. } \\
\text { Sometimes we will put skslights in for LEEDD, but we end up } \\
\text { losing savings with the reconfiguration. Do photocells know } \\
\text { when the racks are in the way? Are lights on or off when they } \\
\text { shouldn't he. }\end{array}$ & Design Consideration & Content & LT & 1 & 3 & 2.6 & 3 & 4 & 4 & 3.7 & 32.6 & 27.7 \\
\hline J Tuenge & JT62 & Core Team & Specialty Market & $\begin{array}{l}\text { Produce - both } \\
\text { ontions }\end{array}$ & 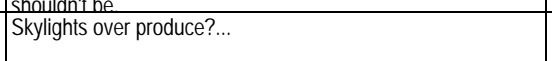 & Design Considerations & Content & LT & 1 & 3 & 2.6 & 3 & 4 & 4 & 3.7 & 32.6 & 27.7 \\
\hline G Subisak & GS12 & Manufacturer & & Download page & $\begin{array}{l}\text { The 60\% range of energy savings is going to be too limited. } \\
\text { Your scale should change. The big box design that I did was } \\
\text { already up to } 57 \% \text { savings. }\end{array}$ & Additions & Content & LT & 1 & 4 & 3.4 & 3 & 4 & 3 & 3.4 & 34.0 & 34.0 \\
\hline Lavis & LD24 & Lighting Designer & Grocery Store & \begin{tabular}{|l|} 
Bakery - Lensed \\
troffers \& \\
Downlights \\
vianette
\end{tabular} & 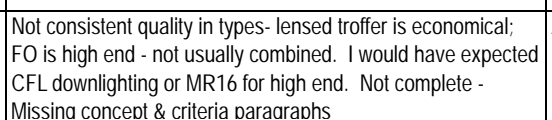 & Additions & Content & 112 & 1 & 5 & 4.2 & 3 & 3 & 3 & 3 & 34.8 & 40.2 \\
\hline LDavis & LD33 & Lighting Designer & Specialty Market & \begin{tabular}{|l|l} 
Vignette Details - \\
Gg Both the
\end{tabular} & 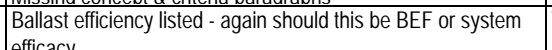 & Validation & Content & 105 & 1 & 4 & 3.4 & 3 & 4 & 4 & 3.7 & 35.8 & 34.5 \\
\hline LDavis & LD9 & Lighting Designer & Discount Big Box & \begin{tabular}{|l|l|l} 
Vignette Docs \\
\end{tabular} & $\begin{array}{l}\text { Quldacy } \\
\text { Quick tip about "lighting produce" - should this be here?; LLF } \\
\text { for lluorescent sources = } 0.761 \text { seemms low with a BF of } 1.0 \\
\text { and high LLD for today's FLlamps. }\end{array}$ & Design Consideration & Content & 112 & 1 & 4 & 3.4 & 3 & 4 & 4 & 3.7 & 35.8 & 34.5 \\
\hline N Miller & NM13 & Lighting Designer & Specialty Market & Barista & $\begin{array}{l}\text { Type C in the Barista has an efficieicycy of 37\% for the CFL } \\
\text { recessed downlight, that's an appallingly low efficiency, even } \\
\text { though I know some CFL fixtures are that poor. Shoot for } 50 \text { - } \\
600 \% \text { instead? }\end{array}$ & Luminaire Changes & Content & 112 & 1 & 4 & 3.4 & 3 & 4 & 4 & 3.7 & 35.8 & 34.5 \\
\hline
\end{tabular}


February 2009

Design

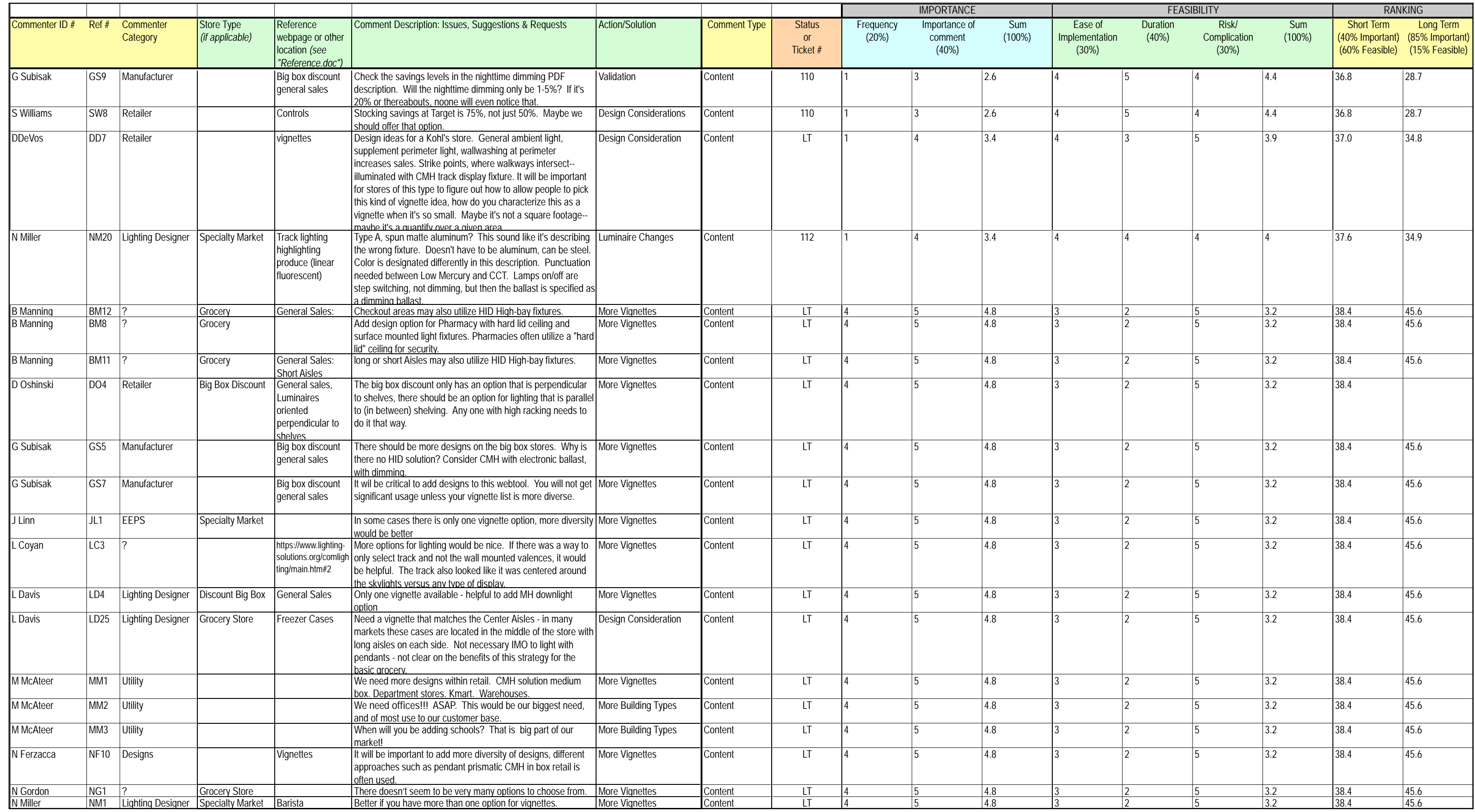




\begin{tabular}{|c|c|c|c|c|c|c|c|c|c|c|c|c|c|c|c|c|c|}
\hline & & & & & & & & & & IMPORTANCE & & & & IBILITY & & & JKING \\
\hline Commenter ID \# & Ref\# & $\begin{array}{l}\text { Commenter } \\
\text { Category }\end{array}$ & $\begin{array}{l}\text { Store Type } \\
\text { (if applica ble }\end{array}$ & \begin{tabular}{|l|}
$\begin{array}{l}\text { Reference } \\
\text { webpage or other } \\
\text { location } / 8: \text { e }\end{array}$ \\
\end{tabular} & Comment Description: Issues, Suggestions \& Requests & Action/Solution & Comment Type & $\begin{array}{c}\text { Status } \\
\text { or } \\
\text { Ticket\# }\end{array}$ & $\begin{array}{l}\text { Frequency } \\
(20 \%)\end{array}$ & $\begin{array}{c}\text { Importance of } \\
\text { comment } \\
(40 \%)\end{array}$ & $\begin{array}{c}\text { Sum } \\
(100 \%)\end{array}$ & $\begin{array}{c}\text { Ease of } \\
\text { Implementation } \\
(30 \%)\end{array}$ & $\begin{array}{c}\text { Duration } \\
(40 \%)\end{array}$ & $\begin{array}{c}\text { Riskl } \\
\text { Complication } \\
(30 \%)\end{array}$ & $\begin{array}{c}\text { Sum } \\
(100 \%)\end{array}$ & $\begin{array}{l}\text { Short Term } \\
\text { (40\% Important) } \\
\text { (60\% Feasible) }\end{array}$ & $\begin{array}{c}\text { Long Term } \\
\left(\begin{array}{l}85 \% \text { Important }) \\
\text { (15\% Feasible) }\end{array}\right.\end{array}$ \\
\hline S Stutzman & SS16 & Retailer & & & There may be some ideas from the Lakewood store that could & More Vignettes & Content & LT & 4 & 5 & 4.8 & 3 & 2 & 5 & 3.2 & 38.4 & 45.6 \\
\hline S Williams & SW5 & Retailer & & Project Description & $\begin{array}{l}\text { Yeu should add a store type that has a dropped celiling design. } \\
\text { Youn }\end{array}$ & More Vignettes & Content & LT & 4 & 5 & 4.8 & 3 & 2 & 5 & 3.2 & 38.4 & 45.6 \\
\hline V Barr & VB1 & State & & & $\begin{array}{l}\text { The building types are strictly limited, I would expect (or at } \\
\text { least hope for) expansion in the future. No options for } \\
\text { assembly spaces, motelsh hotels. etcc. etc }\end{array}$ & More Vignettes & Content & LT & 4 & 5 & 4.8 & 3 & 2 & 5 & 3.2 & 38.4 & 45.6 \\
\hline G Arnold & GA5 & Utility & & Grocery Vignettes & I'm surprised the LPDS aren't lower. Are you using light levels & Validation & Content & 110 & 1 & 3 & 2.6 & 4 & 5 & 5 & 4.7 & 38.6 & 29.2 \\
\hline SMcDonald & SM15 & Generalist & & Vignette Details & $\begin{array}{l}\text { This is all informational and static.... Which I guess is the intent. } \\
\text { You are TELLING ME what to do, right?... the optimal way of } \\
\text { drinothins? }\end{array}$ & Validation & Content & 105 & 1 & 4 & 3.4 & 4 & 4 & 5 & 4.3 & 39.4 & 35.4 \\
\hline VBarr & VB11 & State & & & 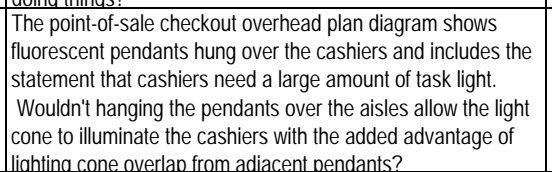 & Design Consideration & Content & 105 & 1 & 4 & 3.4 & 4 & 4 & 5 & 4.3 & 39.4 & 35.4 \\
\hline D Oshinski & DO8 & Retailer & Big Box Discount & & $\begin{array}{l}\text { How do ladd spaceses into this processesi if I have a space that is } \\
\text { not one of your vignettes? There are many spaces besides } \\
\text { customer areas that could save energy. }\end{array}$ & More Space Types & Content & LT & 4 & 4 & 4 & 4 & 3 & 5 & 3.9 & 39.4 & \\
\hline DeVos & DD9 & Retailer & & vignettes & $\begin{array}{l}\text { Can you provide some case lighting ideas? Jewelly cases, for } \\
\text { instance. }\end{array}$ & More Space Types & Content & LT & 4 & 4 & 4 & 4 & 3 & 5 & 3.9 & 39.4 & 39.9 \\
\hline L Coyan & LC9 & ? & & & $\begin{array}{l}\text { Ilike the various design vignettes, but none address the non- } \\
\text { public areas such as receiving docks, offices, etc. There are } \\
\text { opportunities to save energy in the supporting areas as well as } \\
\text { the sales areas }\end{array}$ & More Space Types & Content & LT & 4 & 4 & 4 & 4 & 3 & 5 & 3.9 & 39.4 & 39.9 \\
\hline SWilliams & SW6 & Retailer & Grocery & & $\begin{array}{l}\text { You hisoullat add detailed specs for refrigerated cases. Even } \\
\text { though it's not considered part of the 90.1 savings, it saves } \\
\text { energy. }\end{array}$ & More Space Types & Content & LT & 4 & 4 & 4 & 4 & 3 & 5 & 3.9 & 39.4 & 39.9 \\
\hline G Arnold & GA6 & Utility & & Energy Analysis & $\begin{array}{l}\text { How are you dealing with Additional Lighting Power Allowance } \\
\text { in display areas, in the energy analysis engine, baseline vs. } \\
\text { liahtinn solutions? }\end{array}$ & Validation & Content & 105 & 2 & 4 & 3.6 & 4 & 4 & 5 & 4.3 & 40.2 & 37.1 \\
\hline LCoyan & LC1 & ? & Grocery & & $\begin{array}{l}\text { How is the track lighting calculated? It shows watts per square } \\
\text { foot. Per the energy code, it needs to be calculated at } 30 \text { Whlf. } \\
\text { Is the estimate based on this number? }\end{array}$ & Validation & Content & 105 & 2 & 4 & 3.6 & 4 & 4 & 5 & 4.3 & 40.2 & 37.1 \\
\hline LDavis & LD29 & Lighting Designer & Specialty Market & \begin{tabular}{|l} 
Vignette Details- \\
General Sales \\
Luminaires parallel \\
to shelves
\end{tabular} & $\begin{array}{l}\text { Criteria - range is very broad ( } 45-75 \text { fc) would recommend } \\
\text { narrowing because the max \& min would result in different w/sf } \\
\text { solutions; state what this means (ave maintained, initial, max- } \\
\text { min for a mid range?); }\end{array}$ & Design Consideration & Content & 109 & 2 & 4 & 3.6 & 5 & 5 & 3 & 4.4 & 40.8 & 37.2 \\
\hline L Davis & LD6 & Lighting Designer & Discount Big Box & Vignette Details & 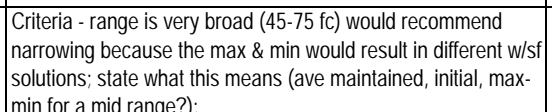 & Design Consideration & Content & 109 & 2 & 4 & 3.6 & 5 & 5 & 3 & 4.4 & 40.8 & 37.2 \\
\hline LDavis & LD19 & Lighting Designer & Grocery Store & 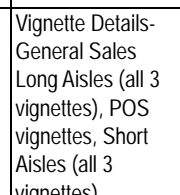 & $\begin{array}{l}\text { Criteria - range i v very broad ( } 45-75 \text { fc) would recommend } \\
\text { narrowing because the max \& min would result in different w/sf } \\
\text { solutions; state what this means (ave maintained, initial, max- } \\
\text { min for a mid range?); }\end{array}$ & Design Consideration & Content & 109 & 2 & 4 & 3.6 & 5 & 5 & 3 & 4.4 & 40.8 & 37.2 \\
\hline L Davis & LD21 & Lighting Designer & Grocery Store & $\begin{array}{l}\text { Monedes } \\
\text { Traduce Vignette } \\
\text { Track Ltg }\end{array}$ & 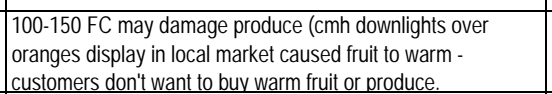 & Design Consideration & Content & 109 & 2 & 4 & 3.6 & 5 & 5 & 3 & 4.4 & 40.8 & 37.2 \\
\hline LDavis & LD11 & Lighting Designer & pharmacy & Vignette & 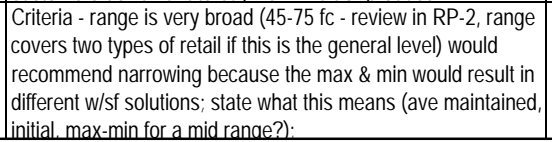 & Design Consideration & Content & 109 & 2 & 4 & 3.6 & 5 & 5 & 3 & 4.4 & 40.8 & 37.2 \\
\hline
\end{tabular}


February 2009

Design

\begin{tabular}{|c|c|c|c|c|c|c|c|c|c|c|c|c|c|c|c|c|c|}
\hline & & & & & & & & & & IMPORTANCE & & & & BILITY & & & KING \\
\hline Commenter ID \# & Ref\# & $\begin{array}{l}\text { Commenter } \\
\text { Category }\end{array}$ & $\begin{array}{l}\text { Store Type } \\
\text { (it p p pliculie) }\end{array}$ & 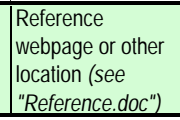 & Comment Description: Issues, Suggestions \& Requests & Action/Solution & Comment Type & $\begin{array}{l}\text { Status } \\
\text { or } \\
\text { Ticket\# }\end{array}$ & $\begin{array}{l}\text { Frequency } \\
(20 \%)\end{array}$ & $\begin{array}{l}\text { Importance of } \\
\text { comment } \\
(40 \%)\end{array}$ & $\begin{array}{c}\text { Sum } \\
(100 \%)\end{array}$ & $\begin{array}{l}\text { Ease of } \\
\text { Implementation } \\
(30 \%)\end{array}$ & $\begin{array}{c}\text { Duration } \\
(40 \%)\end{array}$ & $\begin{array}{c}\text { Risk/ } \\
\text { Complication } \\
(30 \%)\end{array}$ & $\begin{array}{l}\text { Sum } \\
(100 \%)\end{array}$ & $\begin{array}{l}\text { Short Term } \\
\text { (400\% Important) } \\
\text { (60\% Feasible) }\end{array}$ & $\begin{array}{c}\text { Long Term } \\
\text { (85\% Important) } \\
\text { (15\% Feasible) }\end{array}$ \\
\hline L Davis & LD35 & Lighting Designer & Specialty Market & \begin{tabular}{|l|} 
Vignette Details - \\
Produce
\end{tabular} & 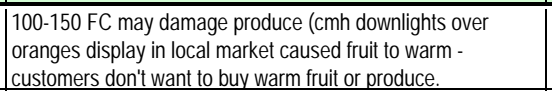 & Design Consideration & Content & 109 & 2 & 4 & 3.6 & 5 & & 3 & 4.4 & 40.8 & 37.2 \\
\hline N Miller & NM18 & Lighting Designer & Specialty Market & \begin{tabular}{|l|}
$\begin{array}{l}\text { Track lighting } \\
\text { highlighting } \\
\text { produce (linear } \\
\text { fluorescent) }\end{array}$ \\
\end{tabular} & $\begin{array}{l}\text { Is the product accent illuminance too high? I would say 50- } \\
100 \text { fc rather than } 100-150 \text { tc. }\end{array}$ & Design Considerations & Content & 109 & 2 & 4 & 3.6 & 5 & & 3 & 4.4 & 40.8 & 37.2 \\
\hline G Subisak & GS8 & Manufacturer & & \begin{tabular}{|l|}
$\begin{array}{l}\text { Big box discount } \\
\text { general sales }\end{array}$ \\
\end{tabular} & $\begin{array}{l}\text { In a big box store, I would expect the daylighting savings to be } \\
\text { greater. When I hit the controls strategy for daylighting it only } \\
\text { changed } 5 \% \text {. Double check the savings calculations. }\end{array}$ & Validation & Content & 110 & 1 & 4 & 3.4 & 5 & & 4 & 4.7 & 41.8 & 36.0 \\
\hline J Tuenge & JT54 & Core Team & Pharmacy & General Vignettes & \begin{tabular}{l|} 
I believe this is the only instance of parallel outperforming \\
perendicura
\end{tabular} & Validation & Content & 110 & 1 & 4 & 3.4 & 5 & & 4 & 4.7 & 41.8 & 36.0 \\
\hline GArnold & GA4 & Utility & Grocery & Grocery Vignettes & $\begin{array}{l}\text { Are we sure that we want to limit users to a max of } 3500 \mathrm{~K} \text { ? } \\
4100 \mathrm{~K} \text { looks good with daylight, and most of these designs } \\
\text { have skvliahts. }\end{array}$ & Design Consideration & Content & 111 & 4 & 4 & 4 & 4 & & 5 & 4.3 & 41.8 & 40.5 \\
\hline N Miller & NM6 & Lighting Designer & Specialty Market & Barista & Expand the color range to $4100 \mathrm{~K}$ & Desigg Consideration & Content & 111 & 4 & 4 & 4 & 4 & & 5 & 4.3 & 41.8 & 40.5 \\
\hline VBarr & VB8 & State & & & $\begin{array}{l}\text { In the NY code, there is a daylighting minimum prescribed. } \\
\text { Designers will want to exceed this minimum to the extent } \\
\text { practicable but the webtool only yses skylights. There edoesn't } \\
\text { seem to be consideration given to other daylighting strategies } \\
\text { like interior reflective surfaces and variable shelvingldisplay } \\
\text { case heichts. }\end{array}$ & Daylighting Guidance & Content & 107 & 4 & 5 & 4.8 & 4 & & 5 & 4.3 & 45.0 & 47.3 \\
\hline LDavis & LD12 & Lighting Designer & Pharmacy & $\begin{array}{l}\text { Center Aisles - } \\
\text { Continous Row } \\
\text { Vignette }\end{array}$ & $\begin{array}{l}8 \text { lamp code is GE trade name, should be generic. } \\
\end{array}$ & Luminaire Changes & Content & 108 & 3 & 5 & 4.6 & 4 & & 5 & 4.7 & 46.6 & 46.2 \\
\hline
\end{tabular}




\begin{tabular}{|c|c|c|c|c|c|c|c|c|c|c|c|c|c|c|c|c|c|}
\hline & 1 & & & & & & & & & IMPORTANCE & & & & BBLITY & & & KING \\
\hline Commenter ID\# & Ref\# & $\begin{array}{l}\text { Commenter } \\
\text { Category }\end{array}$ & $\begin{array}{l}\text { Store Yype } \\
(\text { (iiliplicilis) }\end{array}$ & 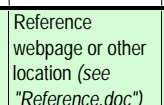 & Comment Description: Isules, Suggestions \& Requests & Action/Solution & Comment type & $\begin{array}{l}\text { Status } \\
\text { or } \\
\text { Ticket\# }\end{array}$ & 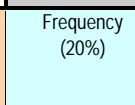 & $\begin{array}{l}\text { Importance of } \\
\text { comment } \\
(40 \%)\end{array}$ & $\begin{array}{c}\text { Sum } \\
(100 \%)\end{array}$ & $\begin{array}{c}\text { Ease of } \\
\text { Implementation } \\
(30 \%)\end{array}$ & $\begin{array}{l}\text { Duration } \\
(400 \%)\end{array}$ & $\begin{array}{l}\text { Risk Complication } \\
(30 \%)\end{array}$ & $\begin{array}{c}\text { Sum } \\
(100 \%)\end{array}$ & $\begin{array}{l}\text { Short Term } \\
(40 \% \text { Important) } \\
\text { (60\%\% Feasible) }\end{array}$ & $\begin{array}{c}\text { Long Term } \\
\text { (85\% Important) } \\
\text { (15\% Feasible) }\end{array}$ \\
\hline $\begin{array}{c}\text { B Hamilion } \\
\text { B }\end{array}$ & BH5 & Core Team & & & 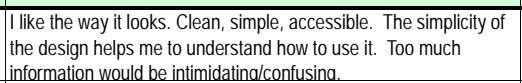 & & Ease of usefflow & & 0 & $\overline{0}$ & $0^{0}$ & 0 & 0 & 0 & $0^{0}$ & 0.0 & 0.0 \\
\hline $\begin{array}{l}\text { B Hamilion } \\
\text { P }\end{array}$ & BH32 & Core Team & & & 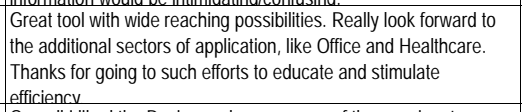 & & General & & 0 & 0 & 0 & 0 & 0 & 0 & 0 & 0.0 & 0.0 \\
\hline B Manning & BM5 & $?$ & N/A & \begin{tabular}{|l|l|l} 
Al user input \\
screans
\end{tabular} & 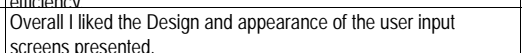 & & $\mid \begin{array}{l}\text { Apperancel/Assthet } \\
\text { ics }\end{array}$ & & 0 & 0 & 0 & $\overline{0}$ & 0 & 0 & 0 & 0.0 & 0.0 \\
\hline $\begin{array}{l}\text { C Dilouie } \\
\text { n }\end{array}$ & CD10 & Manufacturer & & All pages & 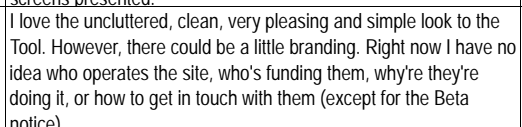 & & Content & & 0 & 0 & 0 & 0 & 0 & 0 & 0 & 0.0 & 0.0 \\
\hline $\begin{array}{c}\text { C Dilouie } \\
\text { n }\end{array}$ & CD20 & Manuffacturer & & & The lighting schedule is cool. & & $\mid$ Download Material & & 0 & 0 & 0 & 0 & 0 & 0 & 0 & 0.0 & 0.0 \\
\hline $\begin{array}{l}\text { CDilouie } \\
\end{array}$ & $\mathrm{CD} 23$ & Manufacturer & & & I like the Luminaire Schedule. & & Download Material & & 0 & 0 & 0 & $\overline{0}$ & 0 & 0 & 0 & $\overline{0.0}$ & 0.0 \\
\hline 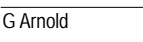 & GA2 & Uutility & & & Graphics are great. & & Apperance/Aesthet & & 0 & 0 & 0 & 0 & 0 & 0 & 0 & 0.0 & 0.0 \\
\hline$G$ Arnold & GA3 & Uutility & & & Screens are simple, that's a good thing. & & Apperance/Aesthet & & 0 & 0 & 0 & 0 & 0 & 0 & 0 & 0.0 & 0.0 \\
\hline $\begin{array}{l}\text { G Amold } \\
\end{array}$ & GA13 & Uutility & & Energy Summary & Very nice. Look and feel is excellent. & & Apperance/Aesthet & & 0 & 0 & 0 & $\overline{0}$ & 0 & 0 & 0 & $\overline{0.0}$ & 0.0 \\
\hline G Subisak & GS3 & Manufacturer & & & $\begin{array}{l}\text { the look of the webtool. Graphics are good. Nice represenation } \\
\text { of the way a store looks, good work With the drawings. }\end{array}$ & & $\begin{array}{l}\text { isperance/Aesthet } \\
\text { ics }\end{array}$ & & 0 & 0 & 0 & 0 & 0 & 0 & 0 & 0.0 & 0.0 \\
\hline G Subisak & GS14 & Manufacturer & & & l like the flow. & & Ease of uselfliow & & 0 & 0 & 0 & 0 & 0 & 0 & 0 & 0.0 & 0.0 \\
\hline G Subisak & GS15 & Manufacturer & & & like the way the screen moves left as you hit next. & & \begin{tabular}{|l|} 
Apperance//Aesthet \\
ics
\end{tabular} & & 0 & 0 & 0 & $\overline{0}$ & 0 & 0 & 0 & 0.0 & 0.0 \\
\hline G Subisak & GS19 & Manufacturer & & $\begin{array}{l}\text { Vignete } \\
\text { Summaries \& } \\
\text { Implementation } \\
\text { Instructions }\end{array}$ & I ike the auto-feed documentation. This is very quick. & & Download Material & & 0 & 0 & 0 & $\overline{0}$ & 0 & 0 & 0 & 0.0 & 0.0 \\
\hline H Mckay & HM5 & Lighting Designer & & & Perspectives are very helpful. & & \begin{tabular}{|l|} 
Apperancel/Aesthet \\
icc
\end{tabular} & & 0 & 0 & 0 & $\overline{0}$ & 0 & 0 & 0 & 0.0 & 0.0 \\
\hline JLinn & JL2 & EEPS & Specially Market & & Text descriptions are well laid out. & & Content & & 0 & 0 & 0 & 0 & 0 & 0 & 0 & 0.0 & 0.0 \\
\hline J Linn & JL5 & EEPS & & Download-Energy & Energy summary layout is nice, readable, right level of detail. & & Content & & 0 & 0 & 0 & 0 & 0 & 0 & 0 & 0.0 & 0.0 \\
\hline JLinn & JL8 & EEPS & & & 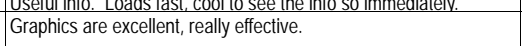 & & Apperance/Aesthet & & 0 & 0 & 0 & 0 & 0 & 0 & 0 & 0.0 & 0.0 \\
\hline JLinn & JL13 & EEPS & & & Flow of the webtool is good. Easy to understand, logical and easy & & Ease of use/flow & & 0 & 0 & 0 & 0 & 0 & 0 & 0 & 0.0 & 0.0 \\
\hline$J$ Jinn & JL14 & EEPS & & & 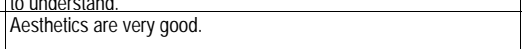 & & Apperance/Aesthet & & 0 & 0 & 0 & $\overline{0}$ & 0 & 0 & 0 & 0.0 & 0.0 \\
\hline JPierce & JP4 & $?$ & & & $\begin{array}{l}\text { Website looks nice. Renderings of vignettes are good. Fairly easy } \\
\text { th navigat through }\end{array}$ & & $\mid \begin{array}{l}\text { AcS } \\
\text { Apperance/Aesthet } \\
\text { ics }\end{array}$ & & 0 & 0 & 0 & 0 & 0 & 0 & 0 & 0.0 & 0.0 \\
\hline K Abernathy & KA4 & LLighting Designer & & & 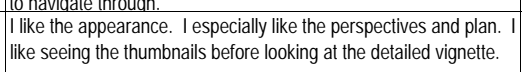 & & $\begin{array}{l}\text { Apperance/Aesthet } \\
\text { ics }\end{array}$ & & 0 & 0 & 0 & $\overline{0}$ & & 0 & 0 & 0.0 & 0.0 \\
\hline KAbernathy & KA5 & Lighting Designer & & & $\begin{array}{l}\text { It's good that it's simple and clean. Dont make it any fancierl! It } \\
\text { could get overcomplicated very quicky, but this amoun of detalis }\end{array}$ & & General & & 0 & 0 & 0 & 0 & & 0 & 0 & 0.0 & 0.0 \\
\hline LCoyan & LC5 & $?$ & & & The site flows easily from one to the next step and backif & & Easentuse/Elow & & 0 & 0 & 0 & $\overline{0}$ & 0 & 0 & 0 & 0.0 & 0.0 \\
\hline
\end{tabular}




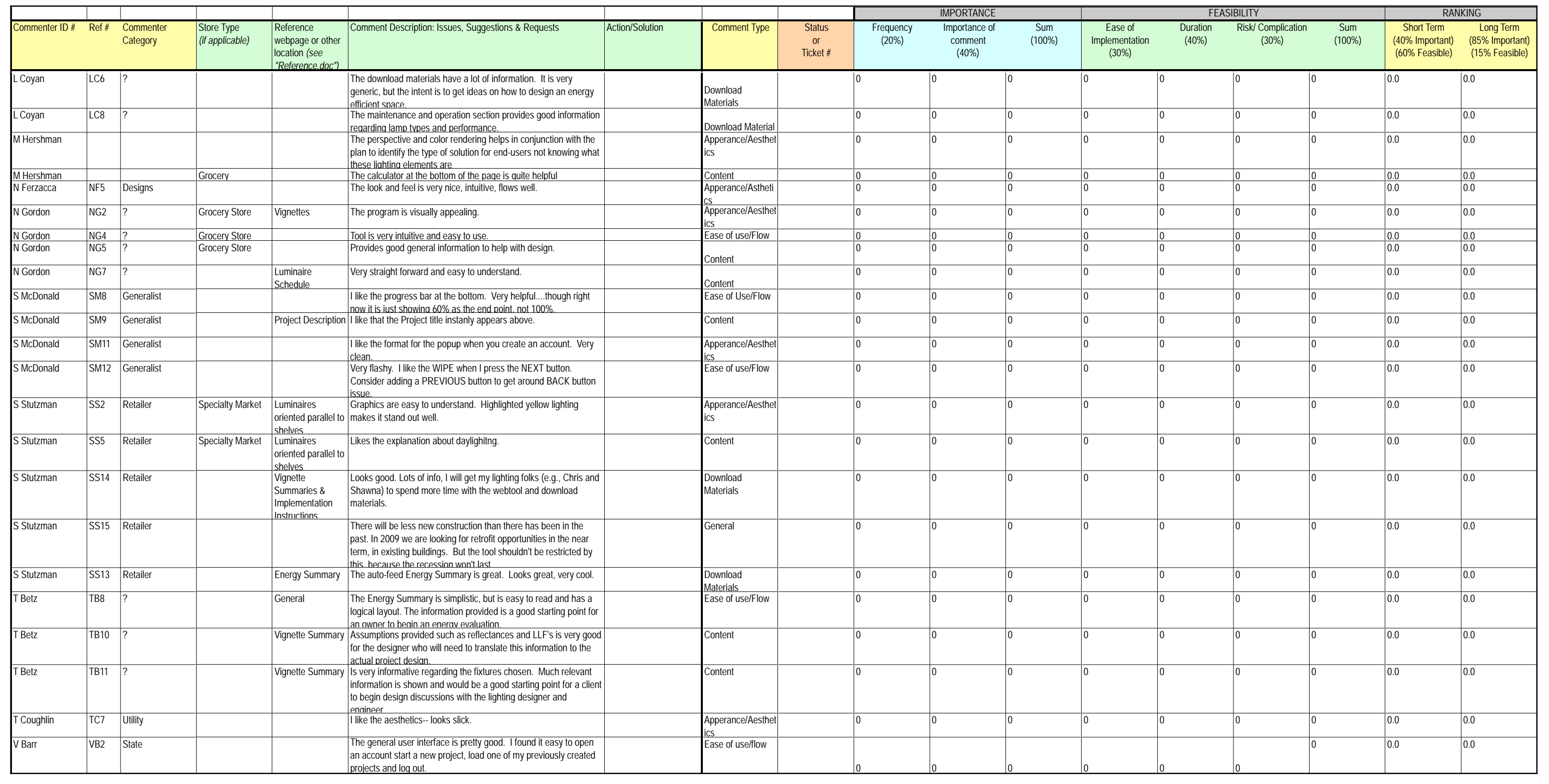




\begin{tabular}{|c|c|c|c|c|c|c|c|c|c|c|c|c|c|c|c|c|c|}
\hline & & & & & & & & & & IMPORTANCE & & & & & & & JKING \\
\hline 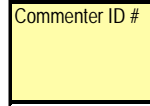 & Ref\# & $\begin{array}{l}\text { Commenter } \\
\text { Category }\end{array}$ & 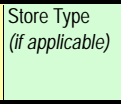 & $\begin{array}{l}\text { Reference } \\
\text { webpage or other } \\
\text { location } / 5: \text { : } \\
\text { lper }\end{array}$ & Comment Description: Issues, Suggestions \& Requests & Action/Solution & Comment Type & $\begin{array}{c}\text { Status } \\
\text { or } \\
\text { Ticket\# }\end{array}$ & $\begin{array}{l}\begin{array}{c}\text { Frequency } \\
(20 \% \%)\end{array} \\
\text { (a) }\end{array}$ & $\begin{array}{l}\text { Importance of } \\
\text { comment } \\
(40 \%)\end{array}$ & $\begin{array}{l}\text { Sum } \\
(100 \%)\end{array}$ & $\begin{array}{c}\text { Ease of } \\
\text { Implementaion } \\
(30 \%)\end{array}$ & $\begin{array}{l}\text { Duration } \\
(40 \% \%)\end{array}$ & $\begin{array}{l}\text { Risk Compication } \\
(30 \%)\end{array}$ & $\begin{array}{l}\text { Sum } \\
(100 \%)\end{array}$ & $\begin{array}{l}\text { Short Term } \\
(40 \% \text { IIportant) } \\
\text { (60\% Feasible) }\end{array}$ & $\begin{array}{l}\text { Long Term } \\
\text { (85\% Important) } \\
\text { (15\% Feasible) }\end{array}$ \\
\hline VBarr & |VB14 & State & & & 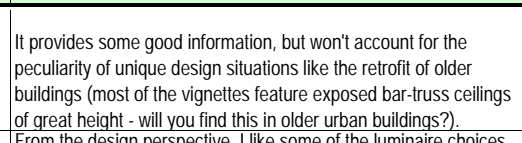 & & Content & & 0 & 0 & 0 & 0 & & 0 & & 0.0 & 0.0 \\
\hline VBarr & VB12 & State & & & 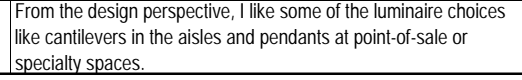 & & Content & & 0 & & & 10 & & & & 0.0 & 0.0 \\
\hline
\end{tabular}

